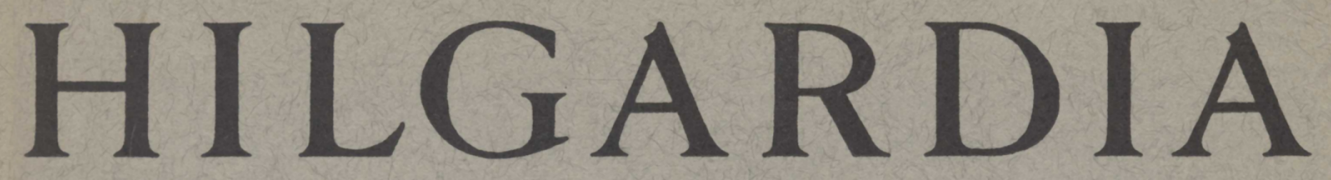

A Journal of Agricultural Science Published by the California Agricultural Experiment Station

\title{
INFLUENCES OF FORESTS ON SNOW IN THE \\ PONDEROSA-SUGAR PINE-FIR \\ ZONE OF THE
}

CENTRAL SIERRA NEVADA

\author{
JOSEPH KITTREDGE
}

UNIVERSITY OF CALIFORNIA - BERKELEY, CALIFORNIA 
The critical importance of water supply problems in the San Joaquin Valley indicates a need for reliable information on the possible effects of forests on accumulation, losses, and melting of snow on the west slope of the Sierra Nevada.

The present study was made in part of the Stanislaus National Forest, and covered the seven years, $1934-38$ and 1940-41. The aim was to find what kinds, sizes, and densities of forests are most effective in promoting accumulation of snow, in minimizing losses by evaporation, and in retarding and prolonging the period of melting.

Recommendations for improved forest management in relation to water supply are made in the light of the findings for the seven seasons under study. 


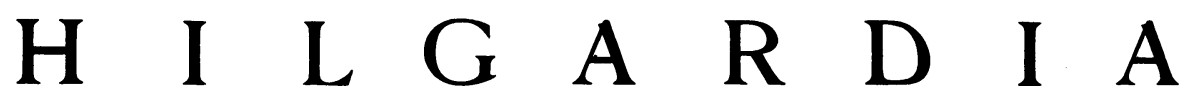

A Journal of Agricultural Science Published by

the California Agricultural Experiment Station

\section{INFLUENCES OF FORESTS ON SNOW IN THE PONDEROSA-SUGAR PINE-FIR ZONE OF THE CENTRAL SIERRA NEVADA ${ }^{1}$}

\section{JOSEPH KITTREDGE}

\section{INTRODUCTION}

The vital IMPORTANCE and high value of water for agriculture, for hydroelectric power, and for life itself require no proof. Much of the water used in the San Joaquin Valley and even in the coastal cities comes from the west slope of the Sierra Nevada, and a large part of that water is derived from melting snow. On the area between the San Joaquin River and the crest of the mountains to the east, over 90 per cent of the precipitation falls on the mountain lands and probably 75 per cent on the forested lands above the zone of oak woodland. About 95 per cent of the snow and 55 per cent of the total precipitation fall on the 40 per cent of the area that includes the mixed conifer, fir, and subalpine forests at elevations above 4,000 feet. For the whole area, snow contributes nearly one half the total precipitation. These figures, and the critical importance of water supply problems, suggest the need of reliable information as to the possible effects of forests on accumulation, losses, and melting of snow, and recommendations on management of forests so that maximum amounts of water may be obtained from the snow.

This study was undertaken in an attempt to answer the question, what kinds, sizes, and densities of forests are most effective in promoting the accumulation of snow, in minimizing the losses by evaporation, and in retarding and prolonging the period of melting?

Three recent reviews of the influences of forests on snow are available and need not be repeated $(21,36,38) .^{3}$ Little information has been published on the subject as it might be applicable to the west slope of the Sierra Nevada. The work of Church $(5,6)$ in the Tahoe-Mt. Rose region on the east side of the mountains, and the studies of Wilm (38), Croft (11), and their associates, in the Rocky Mountain and Intermountain regions, were carried out under quite different conditions, and may or may not be applicable to the Pacific slope of the mountains. Comparisons between the findings of others and those of this study will be made at appropriate points as the subject is developed.

\footnotetext{
${ }^{1}$ Received for publication February 4, 1952.

${ }^{2}$ Professor of Forestry and Forest Ecologist in the Experiment Station, Berkeley.

${ }^{3}$ Italicized figures in parentheses indicate references to "Literature Cited," page 94.
} 


\section{LOCATION AND DESCRIPTION OF AREA}

The records ${ }^{4}$ were obtained in the part of the Stanislaus National Forest within three miles of Pinecrest and Strawberry, in Tuolumne County, at elevations between 5,000 and 6,500 feet. More specifically, the area was in Township 4 North, Range 18 East, Mt. Diablo Meridian. Within this general area the observations were made at 100 snow stations distributed among ten different types of vegetative cover. There were two controls, presumably free from the effects of the forest. The first was a 15 -acre clearing where all vege-

TABLE 1

THE FOREST STANDS AND SITES OF SNOW RECORDS

\begin{tabular}{|c|c|c|c|c|c|c|c|c|}
\hline \multirow{2}{*}{ Forest type } & \multirow{2}{*}{ Age } & \multirow{2}{*}{$\begin{array}{c}\text { Average } \\
\text { height }\end{array}$} & \multirow{2}{*}{$\begin{array}{c}\text { Crown } \\
\text { coverage }\end{array}$} & \multirow{2}{*}{$\begin{array}{c}\text { Ele- } \\
\text { vation }\end{array}$} & \multirow{2}{*}{ Slope } & \multirow{2}{*}{ Aspect } & \multicolumn{2}{|c|}{$\begin{array}{l}\text { Number of } \\
\text { stations }\end{array}$} \\
\hline & & & & & & & $1934-38$ & $1940-41$ \\
\hline Open logged $(\mathrm{OL}) \ldots$ & $\begin{array}{c}\text { years } \\
\ldots\end{array}$ & $\begin{array}{r}\text { feet } \\
0\end{array}$ & $\begin{array}{c}\text { per cent } \\
0\end{array}$ & $\begin{array}{c}f e e t \\
5,200\end{array}$ & $\begin{array}{c}\text { percent } \\
13\end{array}$ & NW & 5 & 5 \\
\hline Open meadow $(\mathrm{OM}) \ldots \ldots \ldots \ldots$ & $\ldots$ & $\mathbf{0}$ & 0 & $5,550^{*}$ & 2 & sw & $5^{*}$ & .. \\
\hline Open screened $(\mathrm{OS}) \ldots \ldots \ldots \ldots$ & $\ldots$ & 0 & 0 & 5,250 & $r$ & NW & 10 & . \\
\hline Ponderosa pine, mature (PPM) ..... & all & 120 & 21 & 5,200 & 15 & SE & 10 & 33 \\
\hline Sugar-ponderosa pine (SP-PP) ...... & all & 140 & 35 & 5,580 & 3 & NW & 10 & .. \\
\hline Mixed conifer, cutover $(\mathrm{MCC}) \ldots \ldots \ldots$ & all & 110 & 37 & 5,550 & 35 & NW & 12 & 31 \\
\hline White fir, mature (WFM) ........... & 140 & 100 & 41 & 5,200 & 31 & $\mathrm{~N}$ & 10 & 32 \\
\hline Red fir $(\mathrm{RF}) \ldots \ldots \ldots \ldots \ldots \ldots \ldots \ldots$ & 200 & 120 & 52 & 6,260 & 21 & $\mathrm{~N}$ & 18 & 35 \\
\hline White fir, immature (WFI) ......... & 70 & 80 & 68 & 5,280 & 16 & NW & 10 & .. \\
\hline \multirow[t]{2}{*}{ Ponderosa pine, reproduction (PPR). } & 28 & 15 & 79 & 5,220 & 10 & $\mathrm{SE}$ & 10 & . \\
\hline & & & & & & & 100 & 136 \\
\hline
\end{tabular}

* For 1938 , four of the stations were moved to another meadow at 6,500 feet.

tation had been cut during a logging operation in 1928 or 1929 . Near the south edge of this clearing, observations were made from the edge of the residual fir forest out into the open area. The second control was a natural mountain meadow of about 10 acres. The different conditions of forest cover included an irregular, all-aged stand of mature ponderosa pine ; a young stand of dense ponderosa pine about 14 feet high and 28 years old; two different stands of quite dense white fir, one approaching maturity and the other somewhat younger, of pole size; a stand of old growth, uneven-aged sugar pineponderosa pine-fir with a volume of over 60,000 board feet per acre, and a similar stand from which 71 per cent of the 294 square feet per acre of basal area (chiefly the larger trees) had been cut in logging; and an uncut, mature stand of red and white fir. Specific information about these stands is given in Table 1, and more silvicultural details of parts of the area are given by Fowells and Schubert (13).

The general area is partly in the drainage of the South Fork of the Stanislaus River and partly in the headwaters of the North Fork of the Tuolumne River. Precipitation records have been taken at Strawberry Lake, and give a mean annual precipitation of 38.65 inches. Fifteen miles to the south, in the

\footnotetext{
4 The work was made possible by the allotment of funds from a special State appropriation for research in forestry in coöperation with Federal agencies.
} 
Tuolumne River drainage at Lake Eleanor (4,650 feet), the precipitation averaged 44.63 inches. At Sonora (1,825 feet), it was 33.22 inches. It is likely that all of these records derived from standard Weather Bureau gages are too low by 10 per cent, and that the mean annual precipitation in the specific area of the study which includes Strawberry Lake is probably about 42 inches. In some years the precipitation, as snow, in this area may be as much as 75 per cent of the annual total. In different years, for the season beginning the last week in December, the number of storms with snow varied from four to 26 .

The runoff in the Stanislaus River (measured just above Knights Ferry) from the total area of 983 square miles averages 26.24 inches (3). The difference between the 42 inches of precipitation and the 26 inches of runoff is 16 inches-a loss which may be explained in part by the forest cover. The percentage distribution of the runoff in the river, by months, is as follows:

\begin{tabular}{|c|c|c|c|}
\hline Month & Per cent & Month & Per cent \\
\hline January.......... & 7.1 & July ............ & 5.6 \\
\hline March........... & 16.6 & September $\ldots \ldots \ldots \ldots \ldots \ldots \ldots \ldots \ldots$ & 0.5 \\
\hline 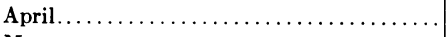 & 17.4 & October $\ldots \ldots \ldots \ldots \ldots \ldots \ldots \ldots \ldots$ & 0.6 \\
\hline
\end{tabular}

\section{METHODS AND DATA}

The collection of data in the field extended throughout the snow season from the end of December to May or June, for seven seasons (1934-38 and $1940-41),{ }^{5}$ and comprised more than 20,000 individual records. The new snow was measured as soon as possible after each storm. All 100 stations were equipped with composition boards 18 inches square, either covered with white cotton flannel or painted white on the rough upper surface. A sample of the new snow was taken on each snow board, and depth was measured by an inverted, 8-inch rain gage. The weight of the core of snow was then converted to water equivalent. The snow boards gave no records for rain, and too low records for those storms in which the part falling as rain exceeded the capillary storage capacity of the new snow. For this reason, in a locality where storms frequently included some rain, only a part of the snow board records could be used. To supplement the snow boards, two or more standard, 8-inch rain gages without funnels were located in each of the ten different cover types. In the seasons of 1940 and 1941, at the open logged area and in the largest opening in the mature ponderosa pine, two gages were mounted on 8-foot towers and equipped with Alter shields. The gages in the woods where wind velocities were low were not shielded. The water equivalents of the precipitation were obtained from these gages at the same time as from the snow boards, by weighing gage and content and converting to inches depth of water. These gages gave records which included rain as well as snow.

The rain gages, with and without the Alter shields, and the snow boards, for storms exclusively of snow, did not give the same records of precipita-

\footnotetext{
5 The season of 1938-39 was not included because of the writer's absence from the state.
} 
tion even when they were located apparently beyond any direct influence of the trees. Some examples will illustrate the magnitude of the differences. The ratios of water equivalents of snow measured on snow boards and in rain gages, in the large clearing or in the meadow in 1935 and 1937, were $0.85,0.90,0.92$, and 0.97 for the same storms of snow without rain. In single storms there were some extreme variations. For the storm of January 14 to 19,1935 , the snow boards caught 3.97 inches and the rain gage, 2.26 inches water equivalent, a ratio of 0.57 . In the storm of March 20 and 21, 1935, the comparison was reversed, and the water equivalents were 1.35 and 1.55 inches, giving a ratio of 1.15 . Differences between means of snow board and rain gage records were statistically significant. Whichever gave the larger water equivalent was used as the record for the storm.

Comparable totals of precipitation caught in the two gages with Alter shields, in 1941, were 32.53 and 31.85 inches. The difference is small but significant. An unshielded gage 190 feet from the shielded ones, in an opening 84 feet across and 28 feet from the nearest crown, caught 41.69 inches, as compared with 39.13 inches in the shielded gage. A half mile away and 300 feet higher, in an opening 12 feet across and 2 feet from the edge of a crown, the catch was $\mathbf{4 5 . 4 5}$ inches in an unshielded gage. Thus it is likely that the records from the shielded gages are lower than the true precipitation, as is true with rainfall at Berkeley (17). The error in some cases may be as much as 15 per cent and, because of lower wind velocities, is doubtless much smaller in the forest than in the open areas.

The depth of the snow on the ground was measured first on a snow stake graduated in inches and set while the ground was bare. Successive measurements on each stake thus avoided the variations due to irregularities in the ground surface that occur when a snow sampler tube is used at different sampling points on successive days. Sampler tube measurements were also taken, however, each time the stake measurements were checked. During the first few years, a Mt. Rose sampler of steel with a spring balance and dial was used, and in the later years a sampler of duralumin with a tubular spring balance. The readings of the balances gave the water equivalents of the snow samples contained in the tubes.

During the last three years, ground water levels were measured by means of well points 3 feet deep at three stations, one in the open logged and two in the mature ponderosa pine area.

From 1938 on, evaporation from the snow was measured at two or three stations in each forest type by the use of aluminum pans 4 inches deep and $12^{1 / 2}$ inches in diameter, coated with aluminum paint. Perforated false bottoms 1 inch above the bottoms of the pans permitted water that melted from the core of snow to drain out of the snow and not form a mass of slush. A core of snow the same diameter as the pan was cut from the surface of the snow close to the station, by means of a core-cutter, and transferred to the pan. The pan and contents were then weighed and set in the snow in a hole (f the same size so that the surface of the snow in the pan was flush with that around it, and so that the upper edge of the pan was the only part which showed at the snow surface. At the next visit, the pan was removed and weighed again, and the differences in successive weighings were converted 
to inches depth of water lost or gained during the periods. When fresh snow or rain fell, the record was lost, and the pan was refilled and set at the nexi visit after the storm. Snow was never observed to blow onto or off the pans between storms, and errors from this source are believed to be negligible.

During the first five years, the stations were located systematically along compass lines through the area to be sampled. Intervals between stations on the different lines varied from as low as 30 -foot spacing, on some, to as high as 130-foot spacing on others. During the last two years, in four of the types, the stations systematically located were supplemented by about 20 randomly located stations in each of the stands, as a check on the use of the data of the systematic sampling, for the evaluation of reliability of derived values. Differences in results between systematic and random sampling were not significant.

Percentage densities of the snow were computed by dividing the water equivalents by the depths recorded in the sampler tubes. The densities multiplied by the depths at the stakes gave the water equivalents used for comparisons on different dates. The differences between successive records at the same stations gave the changes resulting from losses by melting or evaporation, and gains by precipitation.

Snow that remains on the crowns of trees partly falls and partly drips for some time after the end of a storm. Dripping sometimes lasted after precipitation was measured. The rain gages and a limited number of pans under the crowns of trees were examined at each visit, and any snow or water that was caught in them was measured and recorded as drip. The melting of the snow in the crowns was not sufficiently rapid to produce any evident flow of water from the trunks, and even in storms when the snow was mixed with rain the amount of stem flow was considered to be negligible and no attempt was made to measure it. Stem flow was found to be negligible in lodgepole pine and aspen in Colorado (12).

Accumulation of New Snow.-During the seven winters of records there were 110 storms of snow or snow mixed with rain, which yielded 193.2 inches water equivalent of precipitation. The depth of snowfall in the 110 storms was 1,380 inches, or an average of 197 inches per year. The mean annual water equivalent was 27.6 inches, or 66 per cent of the annual precipitation of 42 inches. Because the measurements of snow or rain tend to be too low, the foregoing figures are probably conservative by 5 to 10 per cent. The seven winters of record in this study were closely representative or perhaps a little above the average for accumulation of snow for a longer period of years. Records from the snow survey course at Strawberry Lake, at the same elevation and within half a mile of the open meadow and sugar pine-ponderosa pine stations, show average water equivalents on March 1 of 12.2 inches for the seven years and of 10.9 inches for the 18 years from 1931 through 1948 (4).

Density of New Snow.-The densities of new snow measured shortly after the end of each storm varied from 6 to 16 per cent in storms exclusively of snow, and from 9 to 43 per cent in storms when the snow was mixed with rain. The arrays of densities for individual storms in the seasons of 1937 and 1938, measured in the 15 -acre clearing, are given in Table 2 . The median 
value for the snowfalls in each year is 10 per cent, the factor that has been generally used by the Weather Bureau in converting depth of snow to depth of water. The densities for mixtures of snow and rain may, of course, take almost any values up to the maximum, for something more than capillary saturation, if there is enough rain in relation to the amount of snow. The amount of rain required to increase the density over any desired range can be computed, and is larger than might be expected. For example, 24 inches

TABLE 2

DENSITIES OF NEW SNOW IN SINGLE STORMS IN THE OPEN LOGGED AREA

\begin{tabular}{|c|c|c|c|}
\hline \multicolumn{2}{|c|}{1937} & \multicolumn{2}{|c|}{1938} \\
\hline Snow & Snow and rain & Snow & Snow and rain \\
\hline per cent & per cent & per cent & per cent \\
\hline 6 & . & . & . \\
\hline 6 & .. & .. & .. \\
\hline 7 & .. & . & .. \\
\hline 7 & .. & 6 & .. \\
\hline 8 & . & 8 & 12 \\
\hline 8 & .. & 8 & 13 \\
\hline 8 & 9 & 8 & 14 \\
\hline 10 & 15 & 9 & 15 \\
\hline 10 & 17 & 11 & 17 \\
\hline 10 & 17 & 13 & 18 \\
\hline 11 & 20 & 13 & 20 \\
\hline 11 & 25 & 14 & 22 \\
\hline 12 & .. & 16 & 23 \\
\hline 13 & .. & .. & 29 \\
\hline 15 & .. & .. & 43 \\
\hline Median: 10 & 17 & 10 & 18 \\
\hline
\end{tabular}

of fresh snow of 10 per cent density would retain 5.6 inches of rain before its density increased to 40 per eent if the depth of the snow during the rain decreased to 20 inches.

The percentage densities of freshly fallen snow, in addition to the variations between storms and in different seasons, vary also between stations under the crowns of trees as compared with locations in openings between the crowns. The mean percentage densities for the seven seasons and for five forest types, separated for stations under the crowns and those in the openings, are given in Table 3. The differences in densities, by types and seasons, and the percentages by which the densities under the crowns exceed those in the openings are shown in Table 4. The densities under the crowns are greater than those in the openings by from 1 to 7 per cent, on the basis of seasonal averages, and most of the differences are statistically significant. When expressed as percentage relatives, the densities under the crowns may be more than 30 per cent higher than those in the openings-as in the mixed conifer cutover type in the seasons 1938 and 1940. The percentage differences are greatest in the mixed conifer cutover, and successively smaller in the mature ponderosa pine, mature white fir, sugar pine-ponderosa pine, and red fir. 
The greater density of freshly fallen snow under the crowns doubtless results from the fact that part of that snow falls as masses of various sizes, which first accumulate on foliage and branches. The density of the snow in these masses may have increased as they accumulated. Certainly, since they fall with greater velocities than would single snowflakes, the impact as they hit the snow surface would tend to increase the densities of both the falling mass and of snow already on the ground. If this is the reason for the dif-

TABLE 3

MEAN PERCENTAGE DENSITIES OF FRESHLY FALLEN SNOW UNDER CROWNS (U) AND IN OPENINGS (O), BY SEASONS AND FOREST TYPES

\begin{tabular}{|c|c|c|c|c|c|c|c|c|}
\hline \multirow{2}{*}{ Forest type } & \multirow{2}{*}{$\begin{array}{l}\text { Crown } \\
\text { cover }\end{array}$} & \multicolumn{7}{|c|}{ Season } \\
\hline & & 1934 & 1935 & 1936 & 1937 & 1938 & 1940 & 1941 \\
\hline \multirow[t]{2}{*}{ Mixed conifer, cutover................. } & $\mathrm{U}$ & 32.5 & 20.1 & 28.3 & 13.9 & 29.6 & 21.0 & 31.3 \\
\hline & $\mathrm{O}$ & 22.9 & 17.7 & 23.4 & 12.3 & 22.7 & 15.7 & 24.9 \\
\hline \multirow[t]{2}{*}{ Ponderosa pine, mature. } & $\mathbf{U}$ & 28.7 & 18.0 & 20.6 & 16.4 & 21.9 & 30.5 & 28.5 \\
\hline & $\mathrm{O}$ & 25.3 & 17.1 & 17.8 & 14.1 & 18.3 & 24.7 & 24.1 \\
\hline \multirow[t]{2}{*}{ White fir, mature $\ldots \ldots \ldots \ldots \ldots \ldots \ldots$} & $\mathrm{U}$ & 33.6 & 19.3 & 26.3 & 19.5 & 25.0 & 31.3 & 34.8 \\
\hline & $\mathrm{O}$ & 30.4 & 17.8 & 22.3 & 16.8 & 21.4 & 29.3 & 32.5 \\
\hline \multirow[t]{2}{*}{ Red fir. } & $\mathrm{U}$ & 27.9 & 22.9 & 24.5 & 19.2 & 33.3 & $\ldots$ & $\ldots$ \\
\hline & $\mathrm{O}$ & 28.8 & 21.0 & 22.8 & 17.2 & 29.2 & $\ldots$ & $\ldots$ \\
\hline \multirow[t]{2}{*}{ Sugar-ponderosa pine................. } & $\mathrm{U}$ & 29.3 & 22.6 & 21.9 & 13.8 & 20.2 & $\ldots$ & $\ldots$ \\
\hline & $\mathrm{O}$ & 23.4 & 20.6 & 20.1 & 12.4 & 20.2 & $\ldots$ & $\ldots$ \\
\hline
\end{tabular}

TABLE 4

DIFFERENCES AND PERCENTAGES BY WHICH MEAN DENSITY OF NEW SNOW UNDER CROWNS EXCEEDED THAT IN OPENINGS, BY SEASONS AND FOREST TYPES

\begin{tabular}{|c|c|c|c|c|c|c|c|c|}
\hline \multirow{3}{*}{ Forest type } & \multicolumn{8}{|c|}{ Season } \\
\hline & 1934 & 1935 & 1936 & 1937 & 1938 & 1940 & 1941 & All \\
\hline & \multicolumn{8}{|c|}{ Difference between density under crowns and in openings, per cent } \\
\hline Ponderosa pine, mature $\ldots \ldots \ldots \ldots \ldots$ & $3.4^{*}$ & $0.9^{*}$ & $2.8^{*}$ & $2.3^{*}$ & $3.6^{*}$ & $5.8^{*}$ & $4.4^{*}$ & 3.3 \\
\hline White fir, mature . . . . . . . . . . & $3.2^{*}$ & $1.5^{*}$ & $4.0^{*}$ & $2.7^{*}$ & $3.6^{*}$ & $2.0^{*}$ & $2.3^{*}$ & 2.8 \\
\hline $\operatorname{Red}$ fir $\ldots \ldots \ldots \ldots \ldots \ldots \ldots \ldots \ldots$ & -0.9 & $1.9^{*}$ & 1.7 & 2.0 & $4.1^{*}$ & $\ldots$ & $\ldots$ & 1.8 \\
\hline Sugar-ponderosa pine $\ldots \ldots \ldots \ldots \ldots \ldots$ & $5.9^{*}$ & 2.0 & $1.8^{*}$ & $1.4^{*}$ & 0 & $\ldots$ & $\ldots$ & 2.2 \\
\hline Mixed conifer, cutover . . . . . . . . & 42 & 14 & 21 & 13 & 30 & 34 & 26 & 26 \\
\hline Ponderosa pine, mature... & 13 & 5 & 16 & 16 & 20 & 18 & 18 & 16 \\
\hline White fir, mature........ & 10 & 8 & 18 & 16 & 17 & 7 & 7 & 11 \\
\hline Red fir............... & -3 & 9 & 7 & 11 & 14 & $\ldots$ & $\ldots$ & 7 \\
\hline Sugar-ponderosa pine $\ldots \ldots \ldots \ldots$ & 25 & 10 & 9 & 11 & 0 & $\cdots$ & $\cdots$ & 11 \\
\hline
\end{tabular}

* Indicates difference is significant. 
ference, then it would be expected that the more open types, where wind and sun have access to the crowns, would show larger differences in density than would the less open types. The suggestion tends to be confirmed by the greater differences in the rather open, mixed conifer cutover and mature ponderosa pine types as compared with the white fir, red fir, and uncut sugar pine-ponderosa pine. It may be noted also that the densities in the openings tend to be larger than those in the large clearing as shown in Table 2, page 6 . This may be explained in part in the same way, particularly in the smaller openings in which some of the snow from the crowns would fall, and in part by the fact that the measurements in the forested areas were made a few hours later than were those in the large clearing. On sunny days the density of fresh snow may increase appreciably in a few hours.

TABLE 5

AVERAGE SEASONAL INTERCEPTION IN PER CENT OF SNOWFALL UNDER CROWNS AND IN OPENINGS, BY FOREST TYPES

\begin{tabular}{|c|c|c|c|c|c|}
\hline \multirow{2}{*}{ Forest type } & \multicolumn{3}{|c|}{$\begin{array}{l}\text { Interception as per cent } \\
\text { of precipitation }\end{array}$} & \multicolumn{2}{|c|}{$\begin{array}{c}\text { Crown } \\
\text { coverage* }\end{array}$} \\
\hline & Average & $\begin{array}{l}\text { Under } \\
\text { crowns }\end{array}$ & $\begin{array}{c}\text { In } \\
\text { openings }\end{array}$ & $\begin{array}{l}\text { Under } \\
\text { crowns }\end{array}$ & $\begin{array}{c}\text { In } \\
\text { openings }\end{array}$ \\
\hline Open screened $\ldots \ldots \ldots \ldots \ldots$ & -1.2 & $\ldots$ & -1.2 & $\begin{array}{c}\text { per cent } \\
.\end{array}$ & $\begin{array}{c}\text { per cent } \\
21\end{array}$ \\
\hline White fir, mature ......... & 12.2 & 11.1 & 15.6 & 51 & 41 \\
\hline Ponderosa pine, mature... & 14.5 & 14.9 & 14.1 & 35 & 9 \\
\hline Mixed conifer, cutover..... & 15.1 & 34.2 & -3.0 & 55 & 27 \\
\hline Ponderosa pine, $14 \mathrm{ft}$. high. & 15.4 & 15.4 & $\ldots$ & 40 & .. \\
\hline Red fir.................. & 19.6 & 20.8 & 16.9 & 75 & 2 \\
\hline White fir, pole size $\ldots \ldots \ldots$ & 25.0 & 28.5 & 13.5 & 70 & $\mathbf{5 8}$ \\
\hline Sugar-ponderosa pine...... & 27.5 & 31.3 & 20.1 & 62 & 29 \\
\hline
\end{tabular}

* Average coverage within 20 feet of stations of measurement.

Interception.-Masses of moist snow often accumulated on the branches and foliage. Some of this intercepted snow evaporated before it reached the ground. Because it fell at different times, a little of it may have reached the ground after measurements of the accumulations on snow boards and in rain gages had been made. The amounts measured usually included some of this intercepted snow; thus the figures for interception derived as the differences between the catch of snow in the open and under the trees tend to be conservative.

Part of the snow which lodges on the crowns continues to drip or fall for two or three days following some storms. This is called "drip" although it includes both drops of water and small masses of snow. The amount of drip was measured for five seasons, by pans or rain gages under and near the crowns. In the five years, there were only 14 storms, or 24.6 per cent of the 57 storms in which drip was recorded. There were 43 records of drip in the five seasons, and only four of them measured more than 0.08 inch of water. The average was 0.03 inch. There were no obvious differences in the amount of drip in different forest types or stations. All of the stations with records of drip were within the range from 6 feet outside to 15 feet inside the edges 
of the crowns. The average precipitation in the 14 storms was 1.59 inches. If the average amount of drip is expressed as a percentage of the average precipitation per storm, it is 2.1 per cent, but this figure applies only to the part of the area where drip occurred under the edges of the crowns and only to the 24.6 per cent of the storms that produced drip. Although it

TABLE 6

INTERCEPTION ( $I$ ) OF SNOW IN DIFFERENT FOREST TYPES IN RELATION TO SNOWFALL PER STORM $(P)$, ACCORDING TO THE

REGRESSION, $I=b P+a$

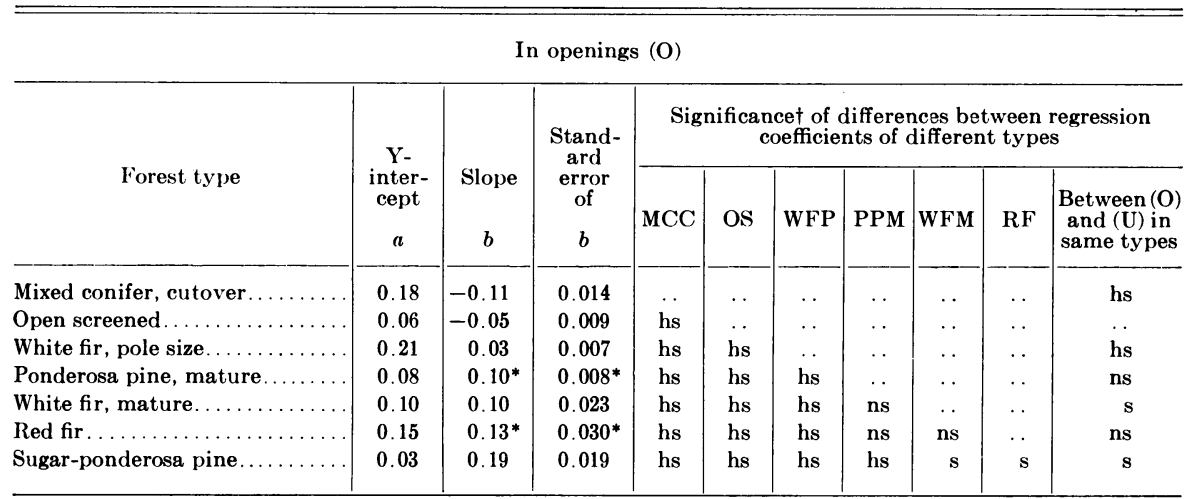

Under crowns (U)

\begin{tabular}{|c|c|c|c|c|c|c|c|c|c|}
\hline \multirow{2}{*}{ Forest type } & \multirow{2}{*}{$\begin{array}{l}\text { Y- } \\
\text { inter- } \\
\text { cept } \\
\quad a\end{array}$} & \multirow{2}{*}{$\begin{array}{c}\text { Slope } \\
\qquad b\end{array}$} & \multirow{2}{*}{$\begin{array}{c}\text { Stand- } \\
\text { ard } \\
\text { error } \\
\text { of } \\
\quad b\end{array}$} & \multicolumn{6}{|c|}{$\begin{array}{l}\text { Significancet of differences between regression } \\
\text { coefficients of different types }\end{array}$} \\
\hline & & & & WFM & PPM & PP, & RF & WFP & $\mathrm{MCC}$ \\
\hline Ponderosa pine, mature........ & 0.09 & $0.10^{*}$ & $0.008^{*}$ & ns & .. & . & . & . & . \\
\hline Ponderosa pine $14 \mathrm{ft}$. high. & 0.01 & 0.11 & 0.039 & ns & ns & $\cdots$ & $\cdots$ & $\cdots$ & $\cdots$ \\
\hline Red fir $\ldots \ldots \ldots \ldots \ldots \ldots$ & 0.30 & $0.13^{*}$ & $0.030^{*}$ & $\mathbf{s}$ & ns & ns & . & . & . \\
\hline White fir, pole size . . . . . . . . & 0.26 & 0.17 & 0.022 & hs & hs & ns & ns & . & . \\
\hline Mixed conifer, cutover......... & 0.25 & 0.24 & 0.014 & hs & hs & hs & hs & $\mathbf{s}$ & . \\
\hline
\end{tabular}

* Data from openings and under crowns combined in one regression coefficient.

$\dagger$ hs=highly significant; $s=$ significant; $n s=$ not significant.

is often suggested that interception of snow is small because of drip, the foregoing measurements indicate that drip is only a minor factor in interception.

In rains, some water runs down the stems of trees and reaches the ground, thus constituting a correction for gross interception. In snowfalls, however, unless heavily mixed with rain, the snow in the crowns melts slowly. Its weight causes the branches to droop so that the water more often runs off the ends rather than back toward the trunks. An appreciable amount of the water that does tend to run down the stems is absorbed by the bark because it is not wet by the snow as it might be by rain. Observation did not indicate 
appreciable stem flow. Measurements of stem flow for lodgepole pine and Engelmann spruce in Colorado showed it to be less than 1 per cent of the precipitation (39). The average for Canary pine near Berkeley was 1 per cent (22). These percentages are for stem flow after rains, and after snowfalls they would certainly not be higher. For ponderosa pine in Califormia, Rowe and Hendrix recorded 3 per cent in storms with 50 per cent or more of snow, and the same percentage in comparable rains (28). Stem flow was not measured in the present study because it was considered to be only a minor factor in the interception of snowfall.

Interception was so highly variable among the different stations within the same stands that the differences between various forest types and between stands of different densities and age were in some cases partially obscured. Results of the analysis of the interception data are contained in Tables 5 and 6 which give the average percentage interception for the different types in ascending order, the percentages segregated for the stations under the crowns and in the openings between the crowns, and the interception in inches depth of water $(I)$ as linear functions of the precipitation per storm $(P)$, also segregated for crowns and openings. The latter relation can be expressed in the form $I=b P+a$, where $b$ is the slope of the regression line and $a$ is the $Y$-intercept, or interception storage capacity of the crowns plus a small amount of evaporation that may have occurred during and immediately after snowfall. The basic data, combined for all years, and the best-fitting trend lines are shown graphically in Figures 1-14. It will be noted that, in several instances, the trends and the equations representing them are not applicable for the estimation of interception in storms of less than 0.7 inch of precipitation. This is because the $Y$-intercept $(a)$, representing interception storage, has a positive value; hence the trends cannot show interception less than the storage for small storms although actually both variables start from the origin of coordinates.

The largest interception for any stand and type was 27.5 per cent of the snowfall in the old-growth sugar pine-ponderosa pine stand mixed with white fir and incense cedar. The immature white fir and red fir stands, both of high crown densities, intercepted 25 and 20 per cent of the precipitation, respectively. The two ages of ponderosa pine and the mixed conifer cutover stand were not much lower, with about 15 per cent interception. The mature white fir showed only 12.2 per cent, which is lower than would be expected for the species and density. The open screened area with only a few trees, near three of the stations along the south side, caught slightly more snow than did the large open area. Its interception was, therefore, negative, -1.2 per cent. For ponderosa pine 70 years old, at 3,350 feet, in California, Rowe and Hendrix (28) recorded 12.8 per cent of snowfall including 3 per cent of stem flow. Old ponderosa pine in Idaho intercepted 25 per cent of the snowfall, and a young, open stand mixed with lodgepole pine intercepted only 5 per cent, according to Connaughton (9). Lodgepole pine and aspen in Colorado intercepted 23 and 16 per cent, respectively, as reported by Dunford and Niederhof (12).

The average snowfall per storm was about 1.8 inches water equivalent. Interception of 20 per cent, for example, represents 0.36 inch that does not 


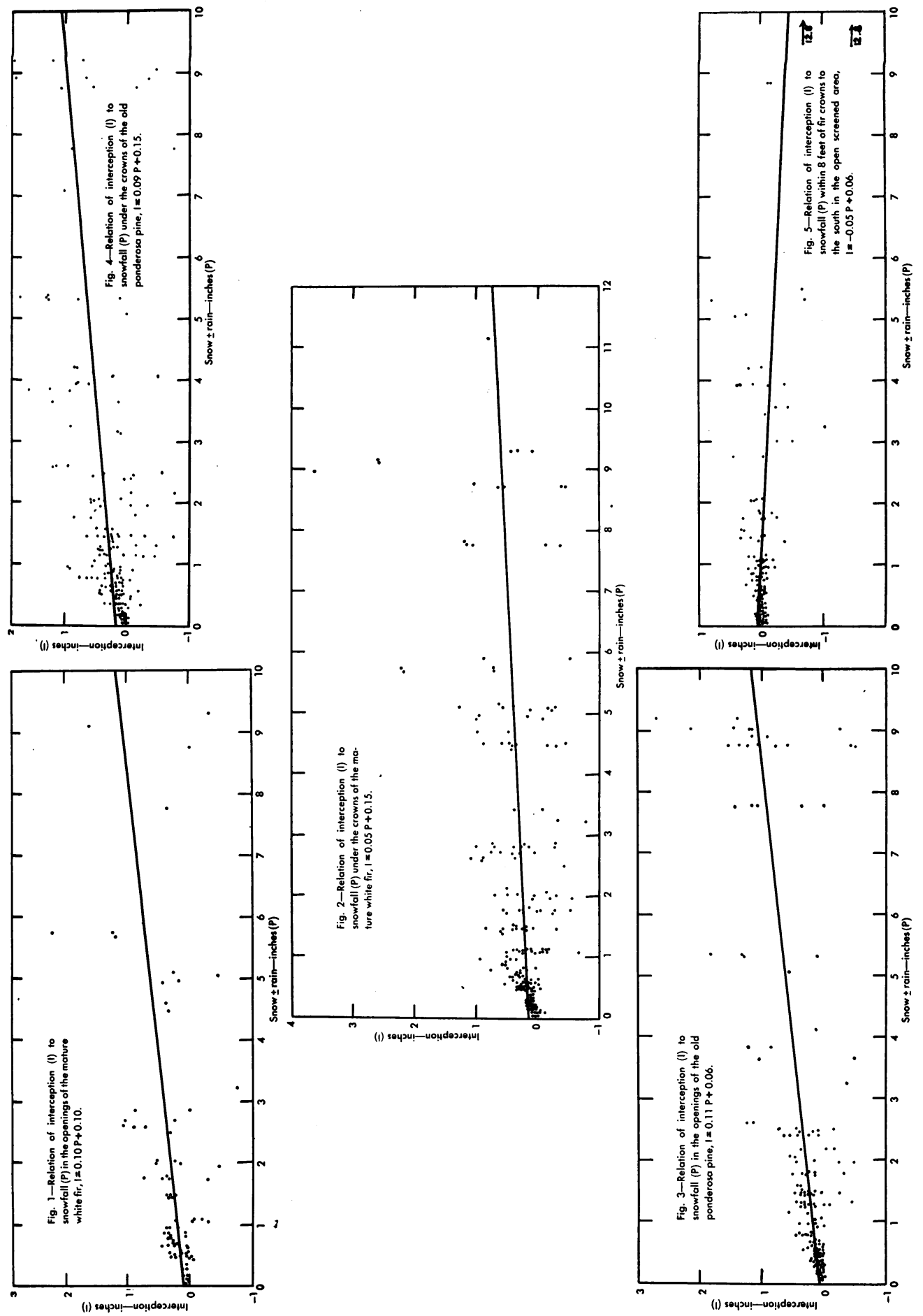




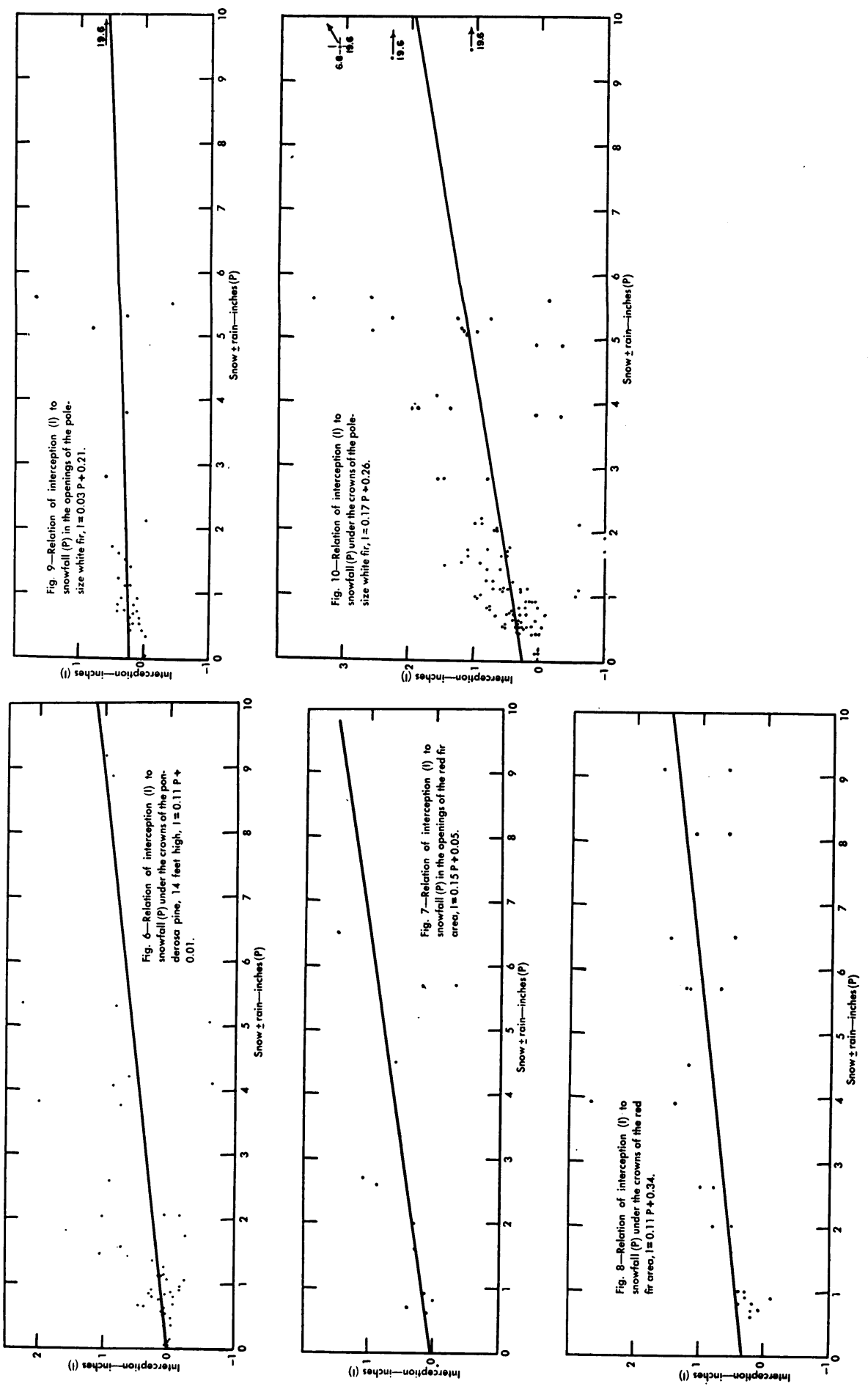



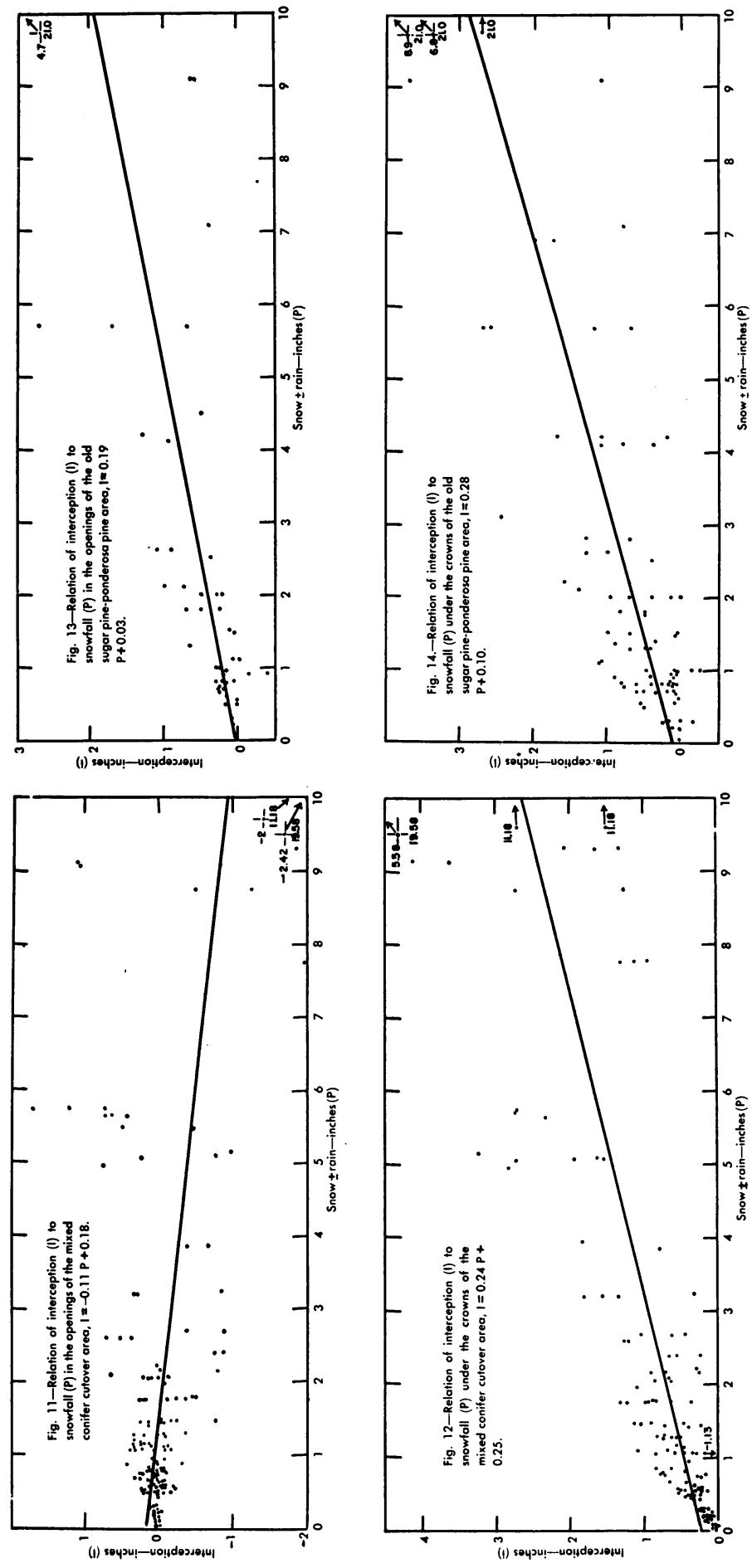
reach the ground. Stem flow and drip are believed to be negligible, but if they amounted to 3 per cent, only 0.05 inch would be accounted for, leaving 0.31 inch which must be attributed to evaporation of the snow on the crowns during and after the storm. Storms of 1.8 inches precipitation usually lasted at least two days, and after the storms some snow remained on the crowns for two or three days. Thus the 0.31 inch of intercepted snow would evaporate in four or five days, or at a rate of perhaps 0.08 inch per day. This is a much higher rate of daily evaporation than the 0.03 inch maximum for any one season and type shown in Table 20 (p. 50) in the later section on evaporation. The higher rate of evaporation in the tree crowns would be expected for several reasons. First, wind velocities are greater at the higher levels, and evaporation increases with wind velocity. Second, the snow in the crowns and the water from its melting are on and surrounded by needles and twigs which are not covered by snow, and which have temperatures 5 to 10 degrees $\mathrm{F}$ above those of the surrounding air, according to Ehlers (12a). These thin films of water would evaporate much more rapidly than would the snow on the ground, and probably at rates higher than those of free water surfaces, for which 0.07 inch per day is an average for Lake Eleanor during the snow season. Third, although the highest seasonal average rate of evaporation from snow on the ground in any type was 0.03 inch per day (table 20, p. 50), there were frequent periods of two or three days when evaporation of more than 0.1 inch per day was recorded. It is not unreasonable, therefore, to conclude that the losses of snow by interception can be attributed to evaporation.

Beneath the crowns of the trees the percentages intercepted were generally higher than the averages for the entire stands. The difference was much the greatest in the mixed conifer cutover where the interception under the crowns was 34 per cent, as compared with 15 per cent for the stand as a whole. This is also the highest percentage under the crowns for any of the stands. Comparing the interception values under crowns and in openings with the corresponding figures for crown coverage in Table 5 , there is a slight positive correlation but not a useable relation.

If the mean water equivalent of the snow under the crowns for each type, as given in Table 15 (p. 45), is deducted from the water equivalent of the open area, the difference, expressed as a percentage of the open, would seem to give another measure of interception. The percentages thus determined, however, are almost twice as large as those in Table 5, and are certainly too high to be reliable. The discrepancies are doubtless caused by the differential changes in the water equivalents in the forested and open areas after the snow fell.

In the openings between the trees, the interception was generally less than the average or than that under the crowns. Again, the greatest difference was in the mixed conifer cutover stand where the interception in the openings was -3 per cent, indicating that more snow was caught in the openings than in the large clearing used as a basis for the percentages. This was also the stand which, as a result of the cutting, had the largest openings between trees. However, the mature ponderosa pine stand, which also had large openings, showed a difference of less than 1 per cent between stations in 
the openings and those under the crowns. Lodgepole pine stands in Colorado intercepted from 32 to 12.5 per cent of the snowfall as the basal area per acre decreased from 159 to 40 square feet in experimental cuttings studied by Wilm and Dunford (38).

The linear relation of the depth of interception to the amount of precipitation per storm was so well defined that all of the regression coefficients in Table 6 were significant notwithstanding the large variations within the same stands. Under the crowns, the coefficients, arranged in ascending order in the table, varied from 0.05 for the mature white fir to 0.28 for the sugar pine-ponderosa pine. The latter figure is the highest for any of the stands, and the former is much lower than would be expected considering the density of the stand. In the openings, the coefficients vary from -0.11 for the cutover mixed conifer to 0.19 for the sugar-ponderosa pine. The negative coefficient indicates that as the precipitation increases, the interception decreases and becomes negative, so that the cutting, by increasing the number and size of the openings, actually increased the accumulation of snow over what would have been found if the whole area had been deforested. Differences of more than 0.05 between coefficients are significant.

The only evidence of a relation between the magnitudes of the coefficients and the crown coverage is found in six of the stations in the cutover mixed conifer, where there is a tendency (shown by the following figures) for the regression coefficients to decrease as the percentages of crown coverage within 20 feet of stations decrease.

Crown coverage, per cent $\begin{array}{lll}76 & 57 & 45\end{array}$ $\begin{array}{lll}40 & 33 & 2\end{array}$

Regression coefficient, inches per inch $\begin{array}{llllll}0.40 & 0.27 & 0.15 & 0.19 & 0.10 & -0.08\end{array}$

The interception storage capacities for these stands (the $y$-intercepts of table 6) vary from 0.01 for the ponderosa pine reproduction to 0.30 for the red fir. Most of these figures are decidedly higher than have been reported for interception storage of rainfall by other species in other localities. This difference is to be expected because snowfall (especially wet snow) tends to accumulate more heavily on the branches of these evergreen species than rainfall ever would. Even in the openings between the trees the interception storage is between 0.10 and 0.21 for the three fir and the mixed conifer stands. On the other hand, it varies between 0.03 and 0.08 for the sugar pine-ponderosa pine and mature ponderosa pine stands. Some of these differences can only be attributed to unsuspected peculiarities of the trees and stands near the stations. The regression equation, $I=0.10 P+0.09$, obtained for mature ponderosa pine in this project, corresponds well with the $I L=0.06 P+0.09$ derived by Rowe and Hendrix (28) from the data for 70 -year ponderosa pine 60 miles to the south at 3,350 feet. Their interception loss $(I L)$ excludes stemflow, which may account for part of the difference in the regression coefficients.

If an estimate of the interception in another stand of one of these types were to be made with the help of the figures in Tables 5 and 6 , it would be possible to make such an estimate in three different ways: (1) The average percentage figures could be applied directly to the snowfall in the other stand-possibly with adjustment for difference in coverage. (2) It would 
be possible to apply the percentages under crowns and in the openings to the percentage of area estimated to belong in each of those two categories. (3) The appropriate regression coefficient and $Y$-intercept from the table, perhaps with suitable adjustments, could be used with records of the snowfall in individual storms to compute the interception per storm and, by summation, that for the season. As usual, in applying such figures to other areas, the more nearly the area for which an estimate was to be made corresponded in location, altitude, precipitation, and character of forest, the higher would be the reliability of the estimate.

TABLE 7

MAXIMUM DEPTHS OF SNOW ON GROUND AND DATES OF OCCURRENCE IN THE SEVEN YEARS, BY FOREST TYPES

\begin{tabular}{|c|c|c|c|}
\hline Forest type & Depth & $\begin{array}{l}\text { Date of } \\
\text { maximum }\end{array}$ & $\begin{array}{c}\text { Days earlier } \\
\text { than date of } \\
\text { maximum } \\
\text { water } \\
\text { equivalent }\end{array}$ \\
\hline Open meadow, 6,500 feet. & $\begin{array}{c}\text { inches } \\
130\end{array}$ & March 27, 1938 & 12 \\
\hline Red fir................. & 105 & April $\quad 8,1938$ & 0 \\
\hline Open logged $\ldots \ldots \ldots \ldots \ldots$ & 94 & Feb. 15,1938 & 36 \\
\hline Open screened $\ldots \ldots \ldots \ldots$ & 92 & Feb. 15,1938 & 50 \\
\hline Mixed conifer, cutover..... & 91 & March 5,1938 & 33 \\
\hline Open meadow, 5,550 feet. . . . . & 83 & Feb. 20,1938 & 44 \\
\hline Ponderosa pine, reproduction... & 83 & Feb. 16,1938 & 35 \\
\hline Sugar-ponderosa pine $\ldots \ldots \ldots \ldots$ & 73 & Feb. 20,1938 & 31 \\
\hline White fir, mature.......... & 65 & March 21, 1938 & 16 \\
\hline White fir, immature....... & 62 & March 5,1938 & 4 \\
\hline Ponderosa pine, mature $\ldots \ldots \ldots \ldots \ldots$ & 61 & Feb. 19,1938 & 34 \\
\hline
\end{tabular}

Total Snow on the Ground.-The snow on the ground at any time is the resultant of the previous falls of fresh snow, adjusted for interception, and the reductions caused by melting and evaporation. Drifting of the snow was not apparent at any of the stations with one possible exception. One station in the open logged area was located near the bottom of a draw some 3 feet below the general level. As the snow accumulated it tended to fill the draw by drifting, if it may be called that, and the resulting depths of snow were decidedly greater than those at the adjacent stations. The lack of drifting is doubtless associated with the low wind velocities in and near the forests.

The measurements of depth and water equivalent at frequent intervals throughout each season provide the basis for trends and comparisons of depths, densities, and water equivalents. All three are of some interest. The depth of the snow is the most obvious property although it is much less useful than the water equivalent in matters of water supply.

Depth of Snow.-The depths of the total snow on the ground tend to increase with the snowfall during the early part of the winter and to decrease as melting exceeds accumulation in the spring period. The maximum depths of snow recorded at any station in each of the forest types and the dates on which those maximums occurred are given in Table 7 . There is a wide variation among types, caused in part by the differences in character and density of the cover and in part by differences in exposure and elevation. Thus the 
two greatest depths of 130 and 105 inches, in the open meadow at 6,500 feet and in the red fir, respectively, are unquestionably attributable to the 800 to 1,000 feet greater elevation of those two areas as compared with the others. More specifically, the open meadow, 950 feet higher, showed 47 inches more snow than the lower one. Similarly, in the most nearly comparable forest areas, the red fir had 40 inches more snow, at an elevation 1,060 feet higher, than did the mature white fir at the lower elevation. In general, the open areas and the forests with large proportions of openings tend to have greater depths of snow than do the denser stands where interception is high. Although the areas were not selected and do not provide unequivocal comparisons of exposures, the minimum of 61 inches in the mature ponderosa pine probably reflects, in part, the south exposure and the consequently earlier and more rapid melting. The sequence of depths also represents the changing relation between interception and excess accumulation in the larger openings between trees. Thus in the white fir stands with only small openings and high interception, the depth is 62 and 65 inches. In the cutover mixed conifer, however, the interception is nearly balanced by the excess accumulation in the frequent large openings, so that the 91 inches for the whole area is almost as great as the 94 in the large clearing where there was no interception.

Marked differences among types and age classes, and in forest openings as compared with open and forested areas, were found in the Swiss streamflow experiment (2). The following depths of snow are 31-year averages from stations at about 3,500 feet. The excesses in the openings between crowns as compared with other conditions of cover are notable. The low values under young fir doubtless reflect the high interception by the dense stand.

\begin{tabular}{|c|c|c|}
\hline \multirow{2}{*}{ Cover } & \multicolumn{2}{|c|}{ Exposure } \\
\hline & North & South \\
\hline & $\begin{array}{l}\text { Depth in } \\
\text { inches }\end{array}$ & $\begin{array}{c}\text { Depth in } \\
\text { inches }\end{array}$ \\
\hline Open $\ldots \ldots \ldots \ldots \ldots \ldots \ldots \ldots \ldots \ldots \ldots$ & 5.8 & 2.4 \\
\hline In openings between crowns $\ldots \ldots \ldots \ldots \ldots \ldots \ldots \ldots \ldots \ldots$ & 10.5 & 5.0 \\
\hline Under groups of beech $\ldots \ldots \ldots \ldots \ldots \ldots \ldots \ldots \ldots \ldots \ldots$ & 6.8 & 3.7 \\
\hline 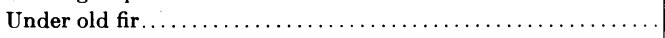 & 3.7 & 3.0 \\
\hline 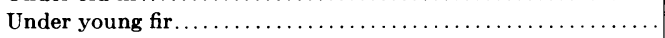 & 3.5 & 1.9 \\
\hline
\end{tabular}

The dates of occurrence of the maximum depths of snow are earlier (usually about the middle of February) in the open areas and on the south exposures, and later (from March 5 to March 21) under the dense stands and on the north exposures in the white fir and mixed conifer types. The dates of maximums are still later at the higher elevations-March 27 in the open meadow and April 8 in the red fir. All of these maximums were recorded in 1938, the season of heaviest snowfall in the seven years of record. The dates of maximum depths of snow are not the same as those of maximum water equivalents. To illustrate the magnitude of the differences, a column has been added in Table 7 to show the number of days by which the maximum depth in each type was earlier than the maximum water equivalent (from table 13, p. 33). The differences in time of the maximums range from 0 in the red fir to 50 
days - the largest-in the open screened area. The larger differences tend to be in the ponderosa pine and open types where the snow is more exposed to sun and wind.

Density of Total Snow.-The density of the snow on the ground, derived by dividing the water equivalent by the depth, is influenced by the recent addition of new snow or rain, by the thawing and freezing of the surface layer, which converts light, fleecy flakes into granular crystals of ice, by the action of wind, and by the loss of water in melting. If a snow layer of 35 per cent density is covered by a layer of new snow of 15 per cent density, obviously the density of the total layer after the fall of the new snow will be less than 35 per cent. On the other hand, if rain falls and is retained in the snow, the water equivalent is increased without a compensating decrease

\section{TABLE 8}

VARIATION IN DENSITY OF SNOW IN MATURE WHITE FIR FOREST AND IN OPEN AREA, ACCORDING TO INTENSITY OF SAMPLING

\begin{tabular}{|c|c|c|c|c|c|c|}
\hline \multirow{2}{*}{ Intensity of sampling } & \multicolumn{2}{|c|}{$\begin{array}{l}\text { Number of } \\
\text { samples }\end{array}$} & \multicolumn{2}{|c|}{$\begin{array}{c}\text { Mean } \\
\text { density }\end{array}$} & \multicolumn{2}{|c|}{$\begin{array}{l}\text { Coefficient } \\
\text { of variation }\end{array}$} \\
\hline & Forest & Open & Forest & Open & Forest & Open \\
\hline Samples within a 14 -inch square.. & 10 & 10 & $\begin{array}{c}\text { per cent } \\
38.4\end{array}$ & $\begin{array}{c}\text { per cent } \\
37.6\end{array}$ & $\begin{array}{c}\text { per cent } \\
4.4\end{array}$ & $\begin{array}{c}\text { per cent } \\
2.4\end{array}$ \\
\hline Lines of samples 3 feet apart $\ldots \ldots \ldots \ldots \ldots \ldots \ldots$ & 22 & 35 & 42.1 & 41.6 & 4.6 & 4.0 \\
\hline Lines of samples 66 feet apart $\ldots \ldots \ldots \ldots \ldots \ldots \ldots$ & 10 & 7 & 41.1 & 42.7 & 4.8 & 4.4 \\
\hline
\end{tabular}

in depth; hence the density is increased. The change in structure as the grains of ice build up by thawing and freezing involves an increase in density because the grains of ice are denser and pack more closely than do the freshly fallen snowflakes. Strong winds in exposed situations have been shown by Church (5) to be highly effective in increasing the density of the snow. However, no evidence of this effect was obtained with the prevailingly low wind velocities in the areas of study. Melting, in so far as it consists of drainage of water out of the snow layer, might cause a reduction in density. However, water only drains from the snow when the density is quite high, and apparently such loss is usually balanced or exceeded by additional water that results from melting at the surface and within the snow layer. Thus the densities actually remain the same or increase slightly as the snow melts. The densities of different layers of the snow are surprisingly uniform, and that of the lower layers is not affected by the weight of overlying snow, according to Work's study at Crater Lake, Oregon (42).

In sampling the snow at different stations within the same area on the same day, some variation in density was found. This was affected only slightly, if at all, by ice or by litter or soil in the tube. Ice was rarely noticed in the sampling, and occasional small amounts of litter or soil were removed before the tube was weighed. On a few days, however, usually when a moist layer of snow at the surface was underlain by dry snow that had a temperature well below freezing, it was difficult to obtain a satisfactory core of snow in the tube even by repeated samplings. If the cores included too little snow, both water equivalent and density records would be affected. 
Most of the sampling was done at stations from 50 to 100 feet apart. Between April 1 and 6, more intensive sampling provided additional information regarding the variation in density. The results of three intensities of sampling are given in Table 8, including the coefficents of variation for different intensities and for the white fir forest as compared with the open area. The variation increased slightly as the samples were more widely spaced,

TABLE 9

DATES ON WHICH SNOW DENSITY REACHED 40 PER CENT IN DIFFERENT SEASONS AND FOREST TYPES

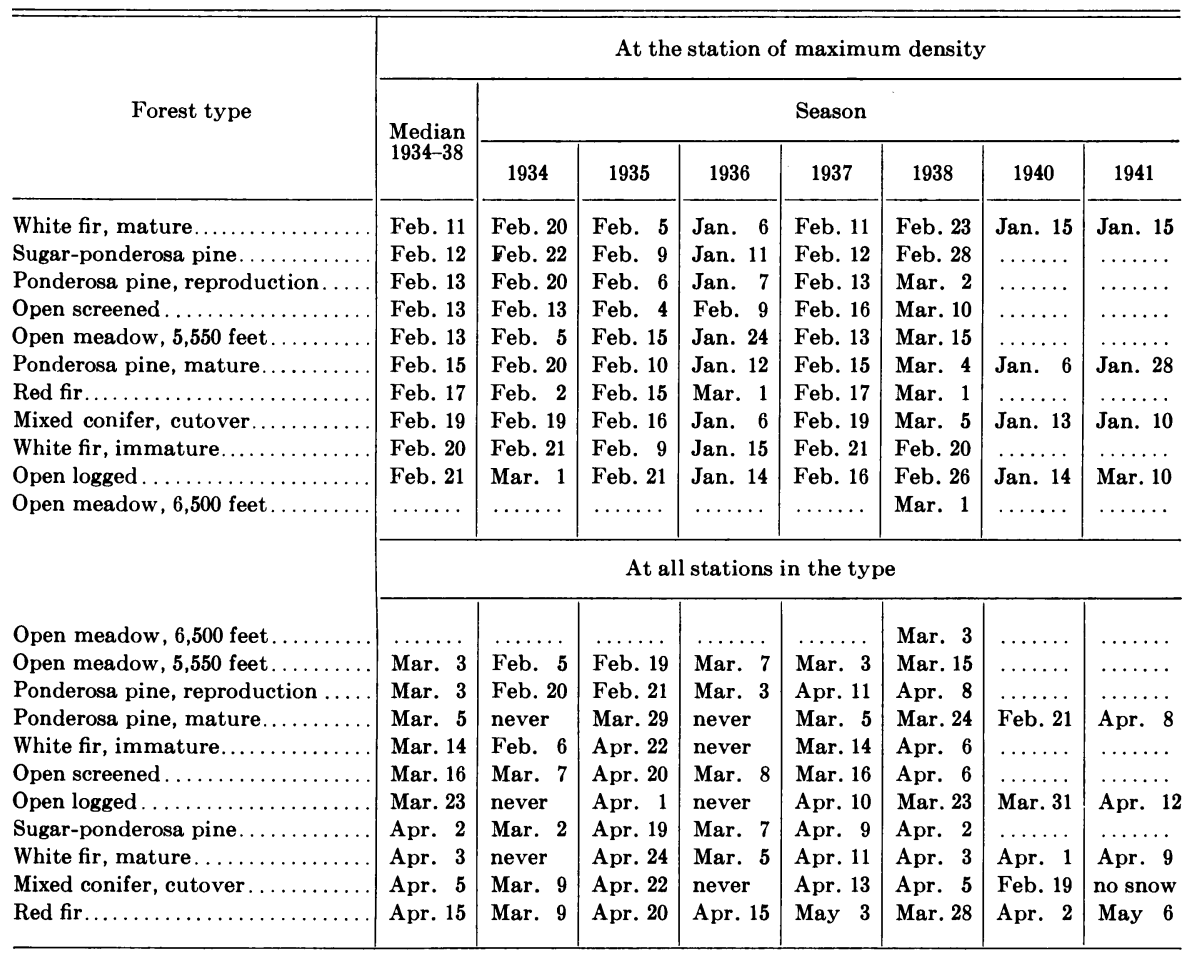

but in the white fir forest the increase was only from 4.4 to 4.8 per cent. In the open area, the coefficient of variation of ten samples only a few inches apart was 2.4 per cent, whereas for samples 66 feet apart, it was 4.4 per cent. As compared with other measurements of the snow, the density is surprisingly uniform within a forest type and even between different conditions of cover.

The density of the snowpack increases during the season, from a low value, when the snow falls, to 50 or 60 per cent at the end. Water begins to drain from the snow when the density of the total snow on the ground reaches about 40 per cent. The date at which the density of the snow reaches 40 per cent, therefore, may be used to indicate the initiation of melting. These dates are shown, for the different forest types and seasons, in Table 9. There may 
be striking differences between seasons. In some years, light snowfall reached 40 per cent density at some stations in January, whereas in 1938, the season of heaviest snowfall, the same density was not recorded at all stations until March or the first week in April. The dates vary from March 3, when all stations in the open meadow showed 40 per cent density, to April 5, in the mixed conifer cutover and April 15 in the red fir. However, the sequence of types in this respect does not have a wholly logical explanation in the records of the density of forest or other characteristics of the different areas. The 40 per cent density at all stations was reached first in the open areas and in the stands of ponderosa pine, whereas the later dates were associated with the denser stands of heavier-crowned species, notably white fir on the north exposures. The immature white fir should be with this latter group, but actually is close to the open screened area probably because of the low accumulation of snow resulting from the high interception. If there is any justification for attempting to generalize from these data, it might be said that drainage of water from the snow is likely to begin about the middle of February at 5,500 feet, to become general before the middle of March in the more exposed areas, and not to begin until the first week in April in the mixed conifer stands on north slopes.

The trend of increasing density of snow as the season advances is seriously interrupted and sometimes entirely obscured by heavy falls of snow or rain at irregular intervals. In the seven seasons of record, the trends were reasonably well defined only in 1937 and 1938, as shown in Figures 15-27. The seasonal changes and rates of increase based on those two years are given in Table 10. The minimum densities, usually less than 20 per cent, are of course found in December or January immediately after the first falls of snow. The maximums of 45 to 60 per cent usually come after the first of April and sometimes after the middle of May. The total seasonal increase of 30 to 50 per cent therefore occurs in periods of from 60 to 135 days. In the seasons of 1937 and 1938, the average daily rates of increase were between 0.28 to 0.44 per cent. At Crater Lake, at 6,450 feet in the open, the rate was also $0.28(42)$.

In contrast with these slow seasonal rates of increase, the high daily increases during short periods without precipitation are much greater, varying from 1.3 to 4.3 per cent when based on the medians of the 15 highest daily rates of increase in the two seasons. These rates of increase for short periods are from 5 to more than 10 times as rapid as the seasonal averages. If these maximum rates of increase should be maintained for a sufficient number of days, the maximum densities would be attained in from 9 to 27 days. In other words, it is possible that a heavy fall of new snow may reach maximum density in excess of the 40 per cent required for melting within two weeks if weather conditions remain favorable for that length of time.

The forest types are arranged in ascending order of the average daily increases in densities for the two seasons combined. On this basis, the denser types with heavy admixtures of fir and the open meadow at the higher elevation of 6,500 feet have the lower rates of increase, and the open areas and those with ponderosa pine have the higher rates. However, the differences between types and between forest and open, in the table and in the graphs, 


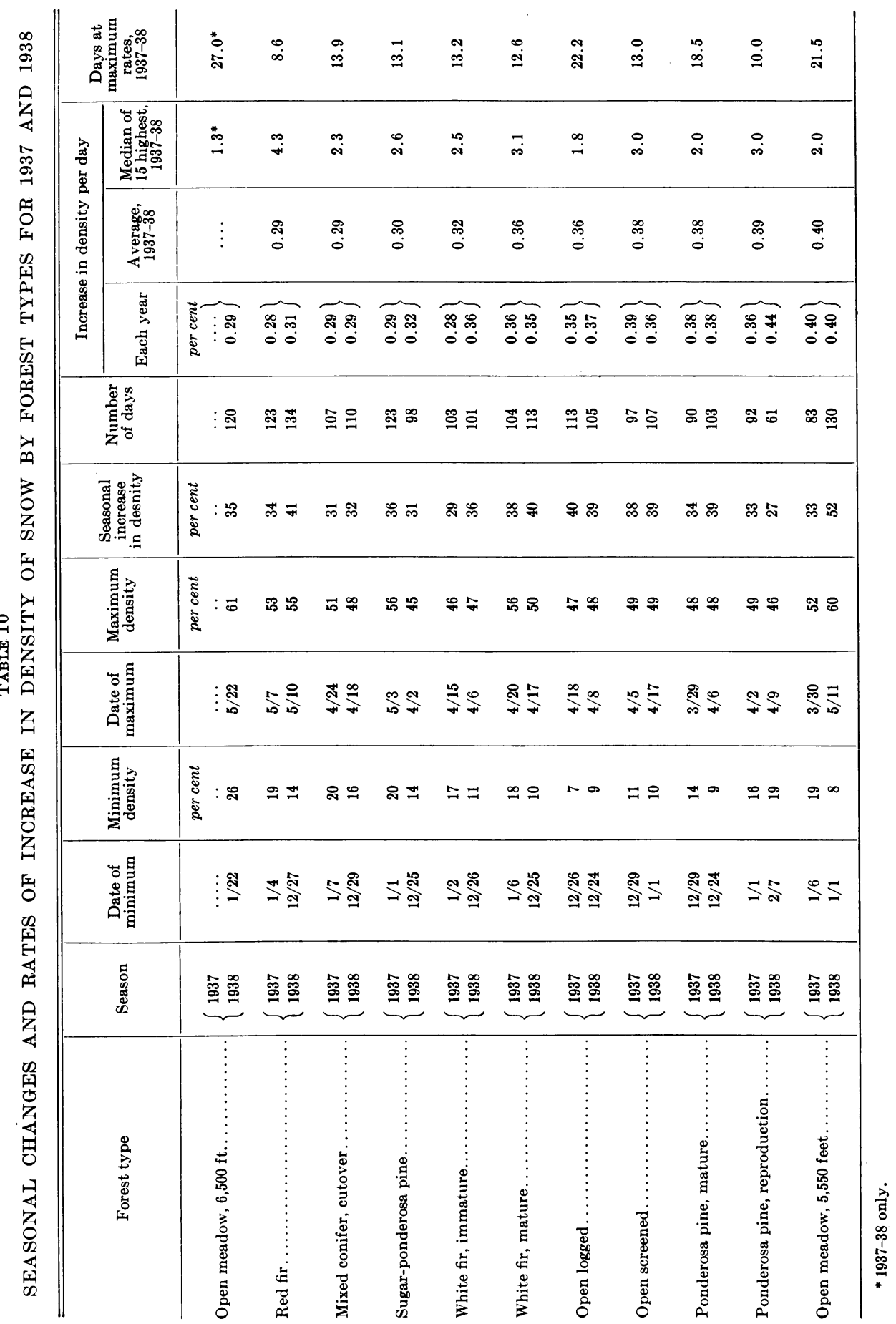



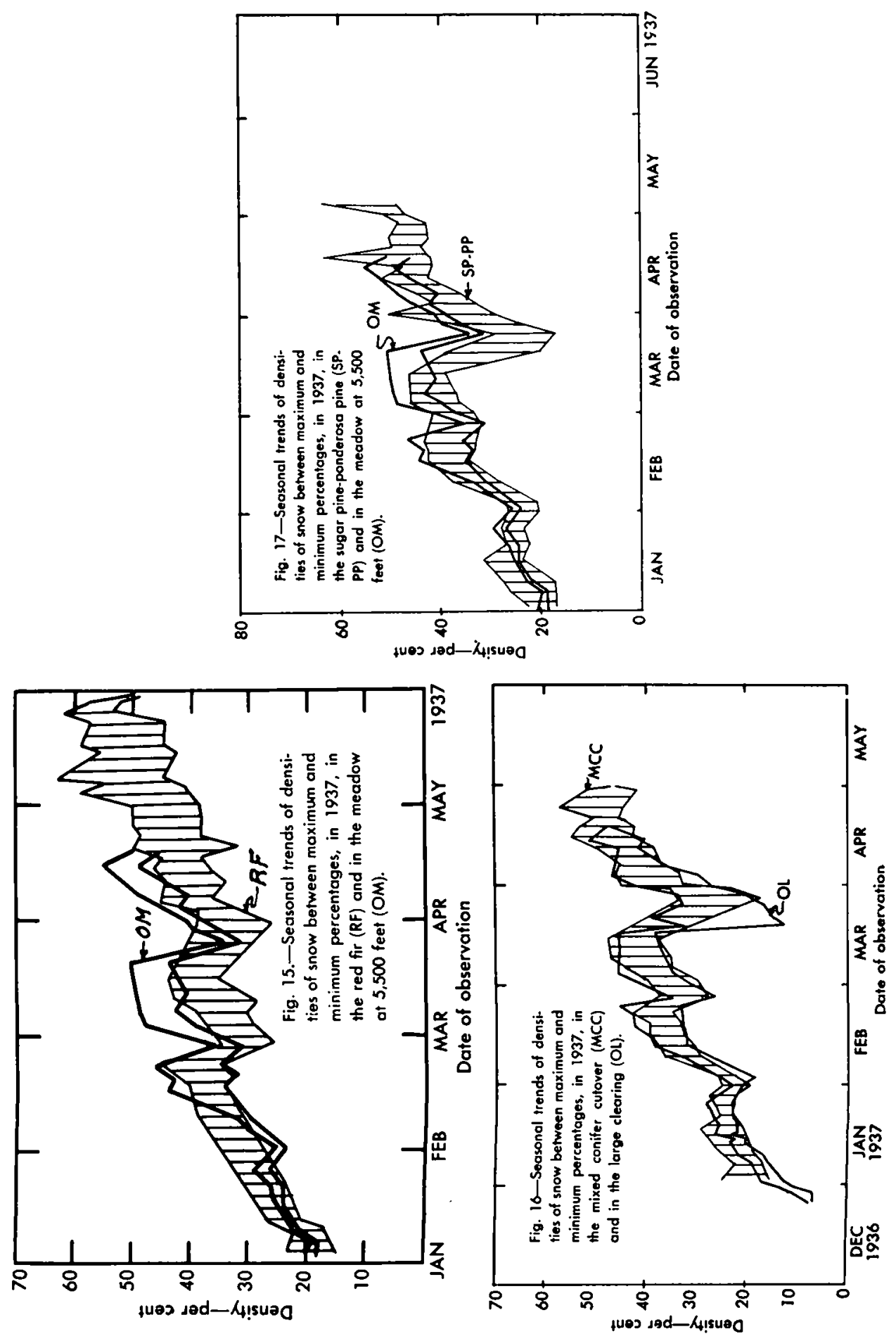

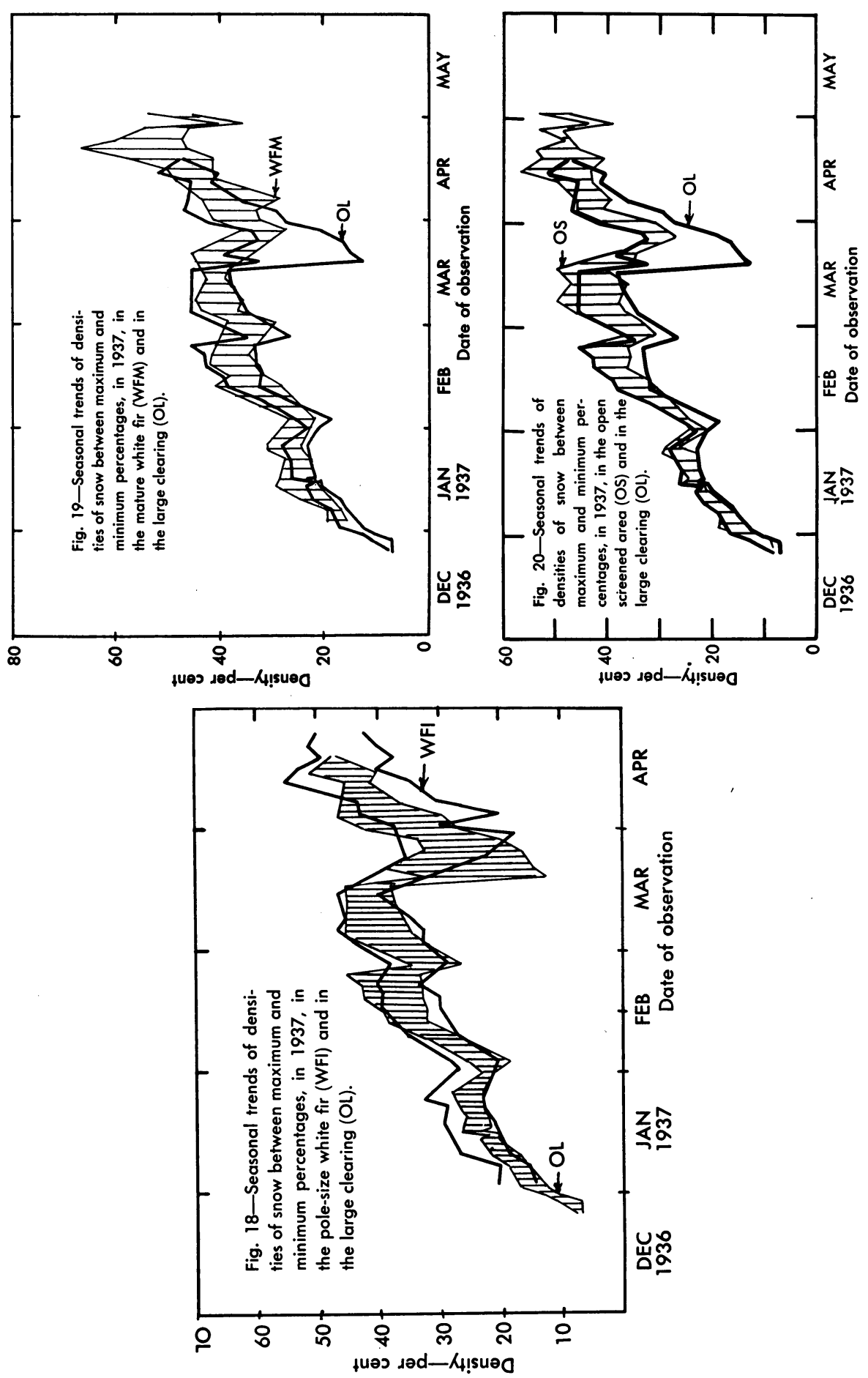

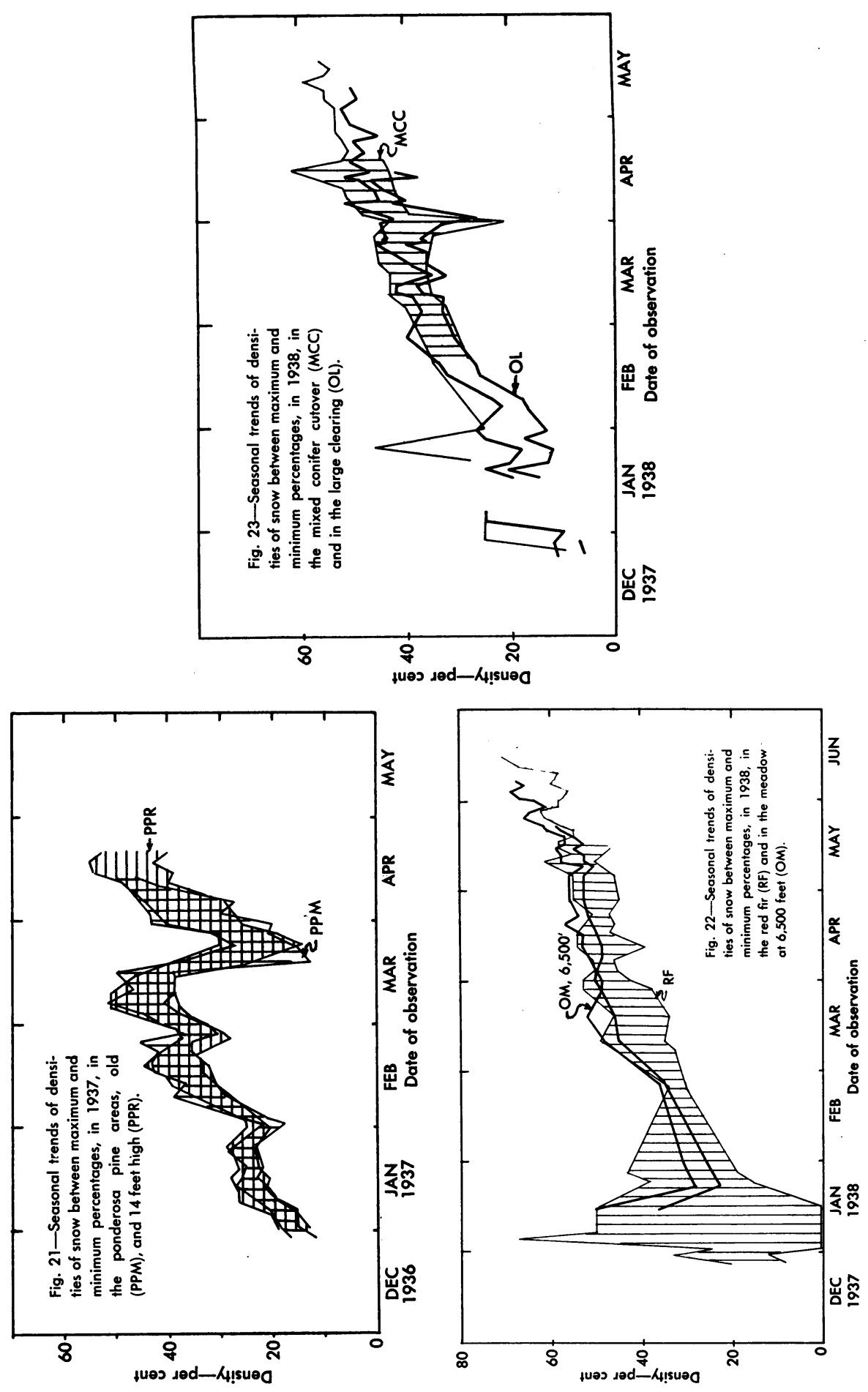

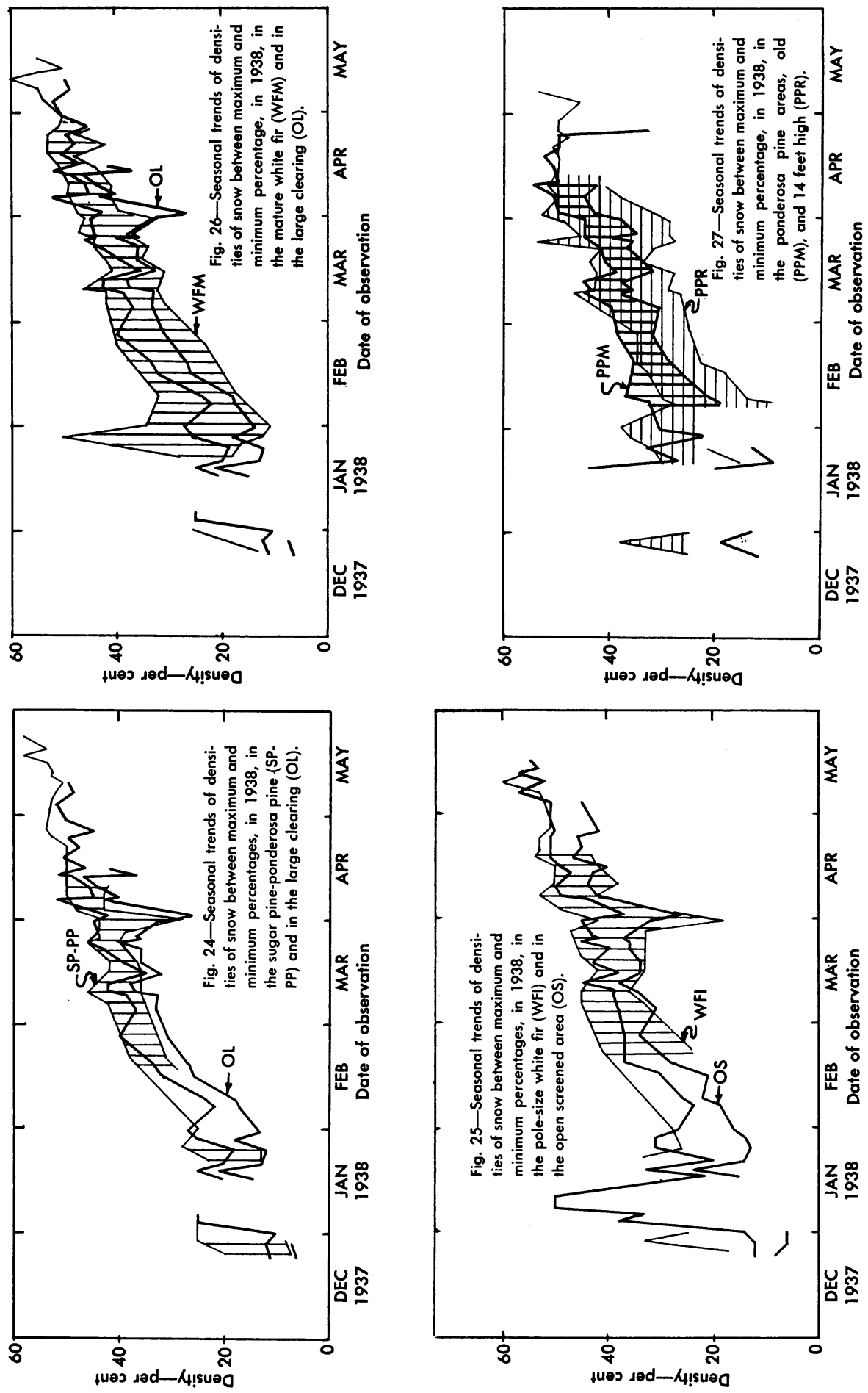


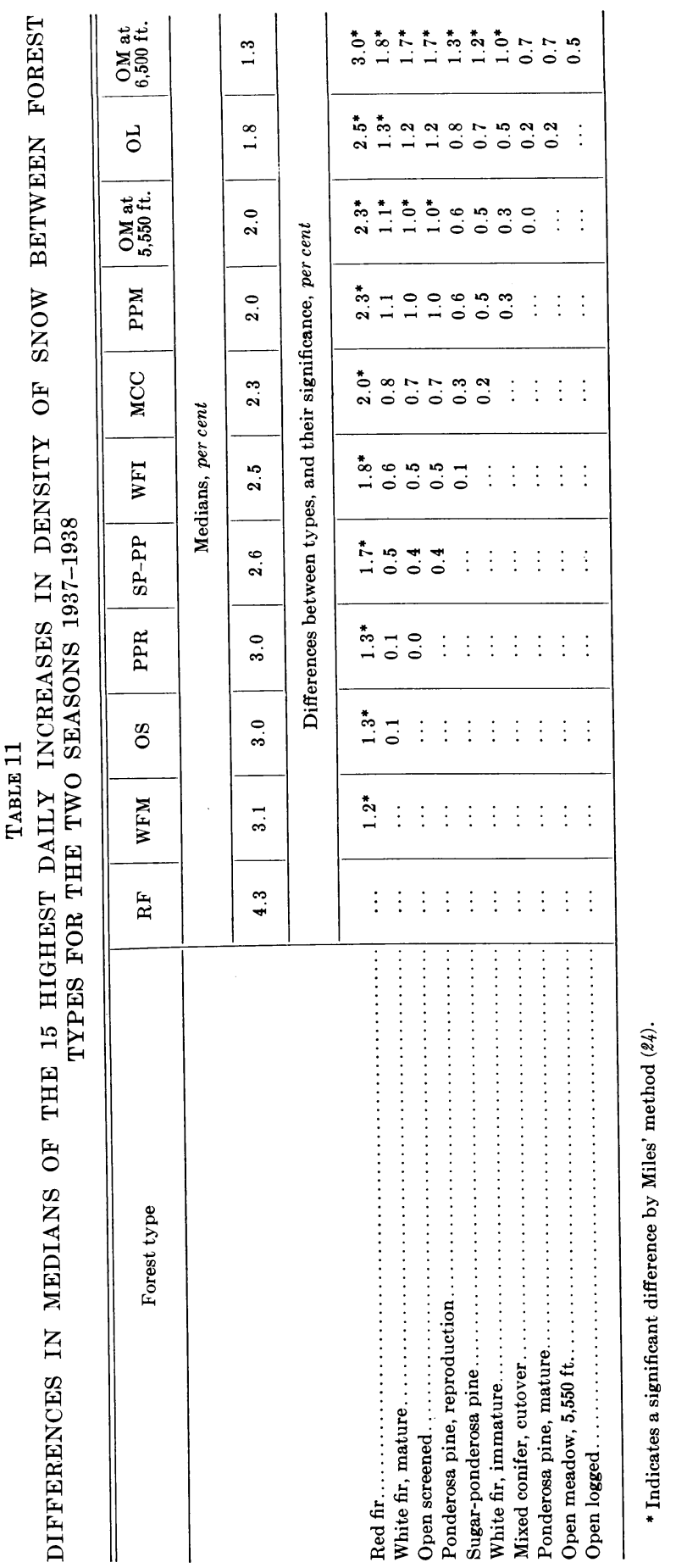


are small and certainly not significant. The maximum spread between the red fir and the open meadow at 5,550 feet is only from 0.29 to 0.40 per cent per day.

The medians of the 15 highest daily increases, arranged in descending order, govern the sequence of forest types in Table 11. The rates of increase in the red fir are significantly higher than in any of the other types. The open meadow at 6,500 feet-the other higher elevation area-shows seven out of ten significant differences. Otherwise, only three of the types are significantly different from one or two of the others. Although the explanation is not obvious, it is of some interest that the red fir and open meadow at 6,500 feet, the two areas at the highest elevation and with the largest accumulations of snow, should show the maximum and minimum rates of increase, respectively.

Table 12

VARIATION IN MEAN WATER EQUIVALENTS OF SNOW ON THE GROUND APRIL 1 TO 6, IN MATURE WHITE FIR FOREST AND IN OPEN AREA, ACCORDING TO INTENSITY OF SAMPLING

\begin{tabular}{|c|c|c|c|c|c|c|}
\hline \multirow{2}{*}{ Intensity of sampling } & \multicolumn{2}{|c|}{$\begin{array}{l}\text { Number of } \\
\text { samples }\end{array}$} & \multicolumn{2}{|c|}{$\begin{array}{l}\text { Mean water } \\
\text { equivalent }\end{array}$} & \multicolumn{2}{|c|}{$\begin{array}{c}\text { Coefficient } \\
\text { of variation }\end{array}$} \\
\hline & Forest & Open & Forest & Open & Forest & Open \\
\hline Samples within a 14 -inch square. & 10 & 10 & $\begin{array}{c}\text { inches } \\
9.1\end{array}$ & $\begin{array}{c}\text { inches } \\
12.5\end{array}$ & $\begin{array}{c}\text { per cent } \\
4.7\end{array}$ & $\begin{array}{l}\text { per cent } \\
\quad 3.2\end{array}$ \\
\hline Lines of samples 3 feet apart.... & 22 & 35 & 10.9 & 13.3 & 15.5 & 11.1 \\
\hline Lines of samples 66 feet apart. . & 10 & 7 & 11.5 & 12.9 & 25.4 & 18.5 \\
\hline
\end{tabular}

Water Equivalents of Total Snow on the Ground.-The water equivalent of the snow on the ground or the inches depth of water in the snow if it were melted is perhaps the most important characteristic of the snow from the point of view of water supply. It provides a direct measure of the amount of water in storage in the form of snow although not all of that water will necessarily appear in the channels as streamflow. The water equivalent, sometimes called water content of the snow, is reported regularly in the snow surveys carried out in many states.

Most of the samplings of the water equivalent of the snow were spaced at distances of 30 to 130 feet between sampling points. On several occasions, however, this was supplemented by more intensive sampling along lines at intervals of 3 feet and by taking 10 samples within an area 14 inches square. The mean water equivalents and the coefficients of variation for forest and open areas, by these three intensities of sampling, are given in Table 12 . The mean water equivalents in inches depth vary only a little according to the intensity of sampling either under the forest or in the open. The greater water equivalent in the open would be greater in about the same amount by any of the three methods. On the other hand, the variation within the series of samples, by each method, increases strongly as the distance between the samples is increased. Thus, in the open, the coefficient of variation for 10 samples within a 14-inch square was about 3 per cent; for samples 3 feet apart, 11 per cent; and for samples 66 feet apart, almost 19 per cent. The 
corresponding figures under the forest were in every case larger, and increased from a little less than 5 to more than 25 per cent as the spacing of the samples increased. Thus, the relative variation between samples becomes much greater if the samples are widely spaced. This would be a consideration in planning sampling where wide spacing might seem desirable in order to be representative of a large area. The figures also indicate that for any desired degree of reliability, it would be necessary to take more samples as the spacing between samples is increased. Using the figures in Table 12 as a basis, if it were desired to determine the mean water equivalent of the snow within 10 per cent of the true mean, with a probability of 95 per cent, it would be necessary, at the 66-foot spacing, to take 14 samples in the open or 26 in the forest. With 3-foot spacing, only 5 samples in the open and 10 in the forest would be needed for the same reliability. Apparently about twice as many samples would be necessary in a forested area as, for example, in an open meadow, for the same accuracy. If the intervals between sampling points were increased above 66 feet, the required number of samples probably would not increase rapidly.

There are wide differences in the water equivalents of the snow on the ground in different seasons and among the different conditions of forest cover. Figures 28 to 41 show the seasonal trends of maximums and minimums for 1938, the year of heaviest snow, and for 1936, a less than average year. The seasonal differences reflect the well-known variations in winter precipitation, while the differences between forest types indicate differences in interception and melting and, to a smaller extent, in density and evaporation. For each of the seven seasons of record, the maximums of the water equivalents of the snow at the station within the type where the maximum accumulation was recorded are shown in Table 13. The types are arranged in descending order of the mean water equivalents for the five seasons, 1934 through 1938. The means range from 32.9 inches in the red fir to 11.7 inches in the mature ponderosa pine. The low figures for the two ponderosa pine types doubtless reflect, in part, the influence of the southern aspects on which the snow was exposed. The high figure for the red fir represents, in part, the greater snowfall at an elevation 800 to 1,000 feet higher than those of the other types. At the time of maximum accumulation of snow, the difference of 950 feet elevation between the upper and lower meadows was associated with a difference of 34.5 inches water equivalent at the maximum stations and of 21.5 inches at the minimum. Similarly comparing the red fir and mature white fir areas, 1,060 feet difference in elevation resulted in differences of 18.4 and 8.7 inches water equivalent, respectively. Although both pairs of comparisons show marked increases of water equivalent with elevation, the increases in forested areas are smaller than those in the open meadows. A relation applicable to a large area, therefore, would require more data from different elevations.

The dense stands of white fir with 12.5 and 14.5 inches water equivalent indicate the effect of the high interception of snowfall by the dense crowns. The maximum accumulation in the sugar pine-ponderosa pine old growth stand is not very different from that in the open areas. The 20.9 inches in the mixed conifer cutover stand with large openings (the result of logging) is, on the average, a little larger accumulation of snow than that in the open areas. 

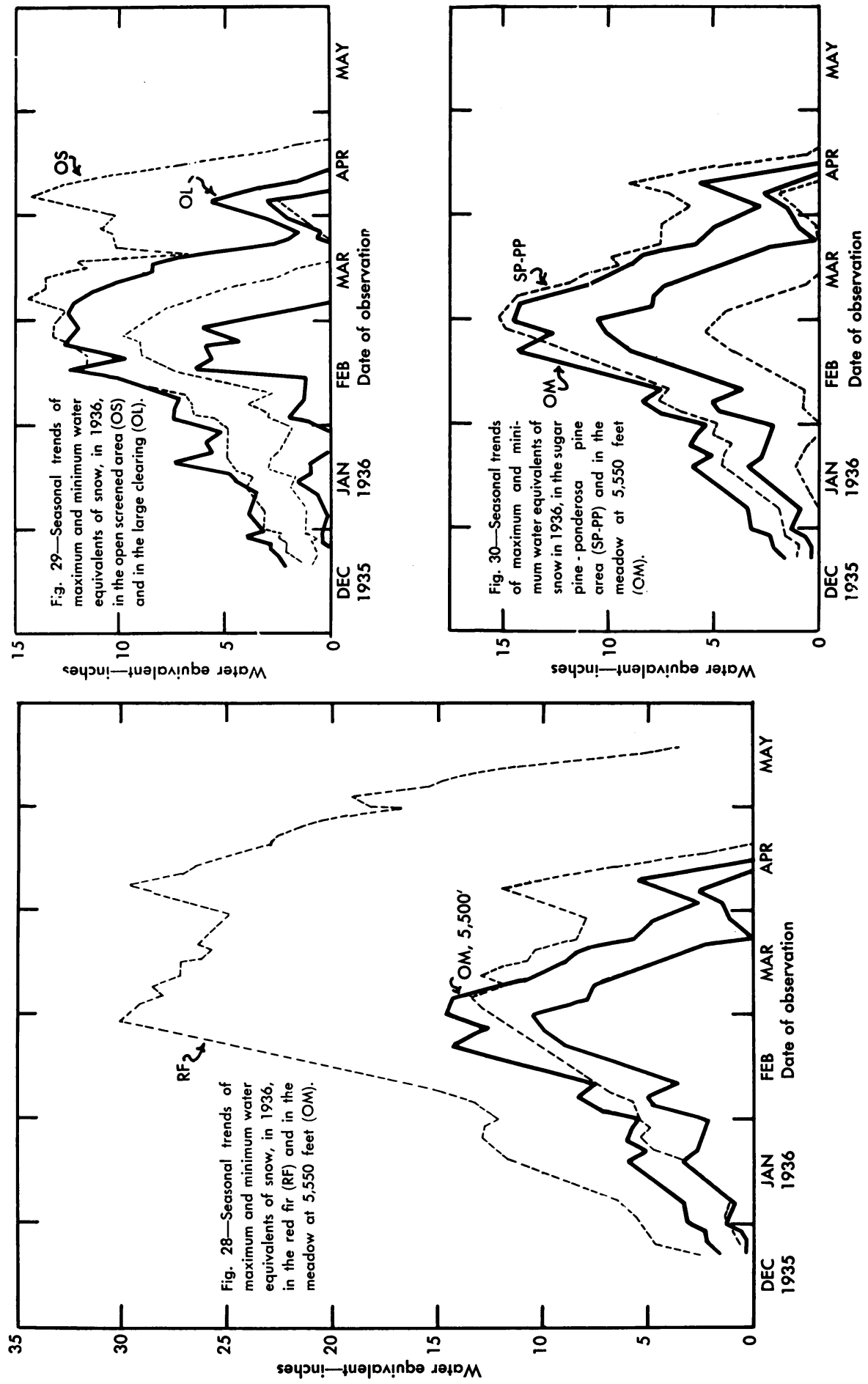

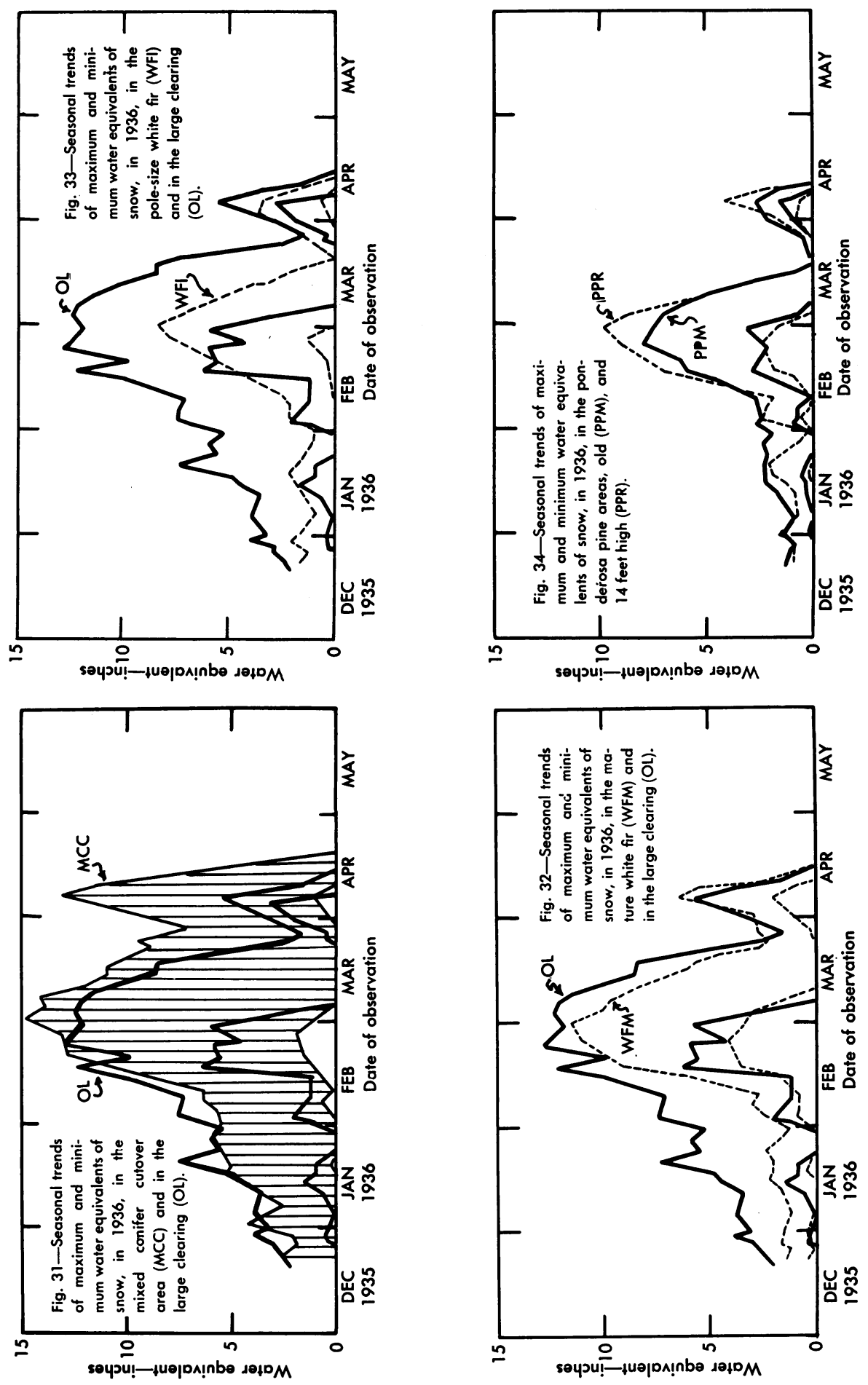

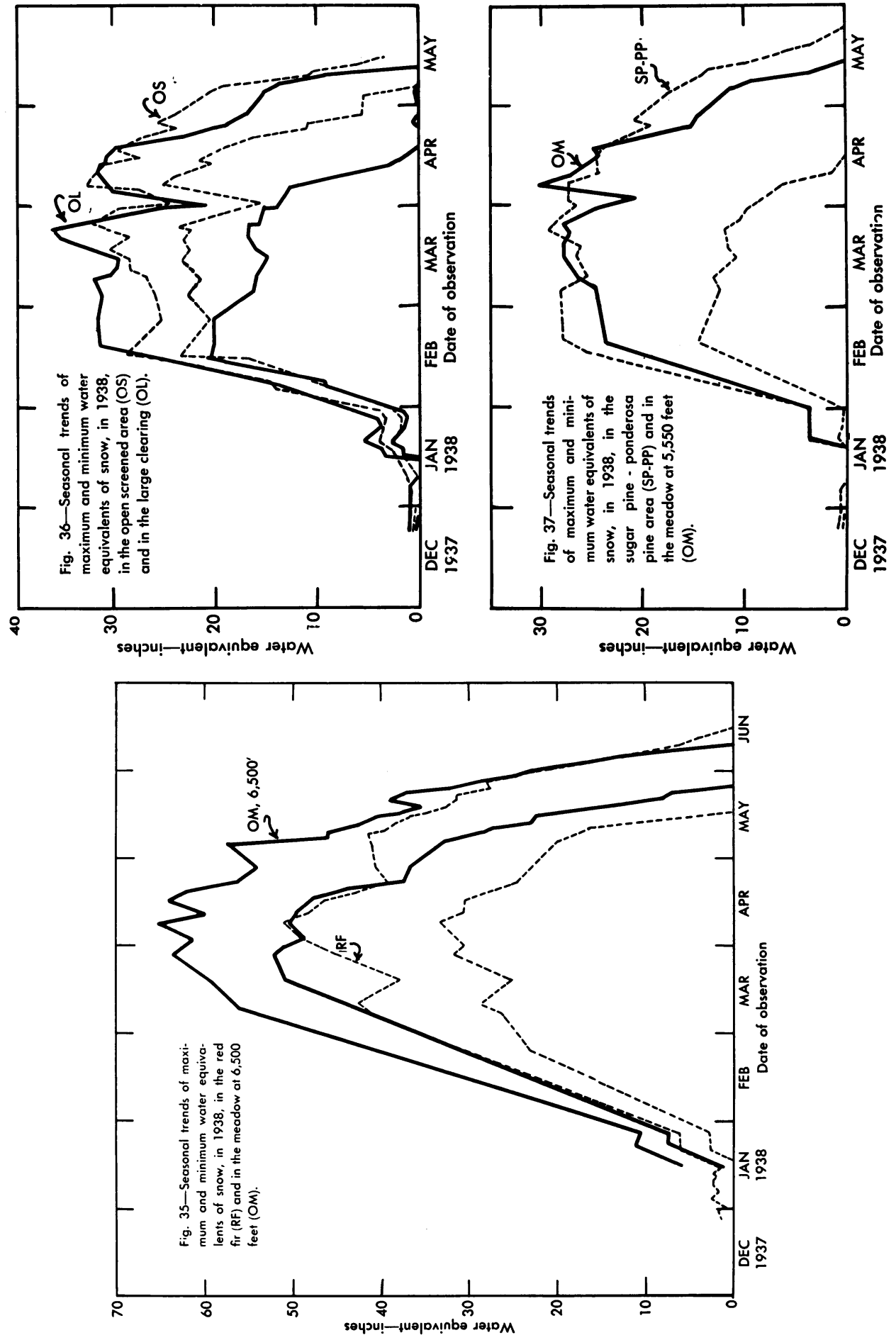

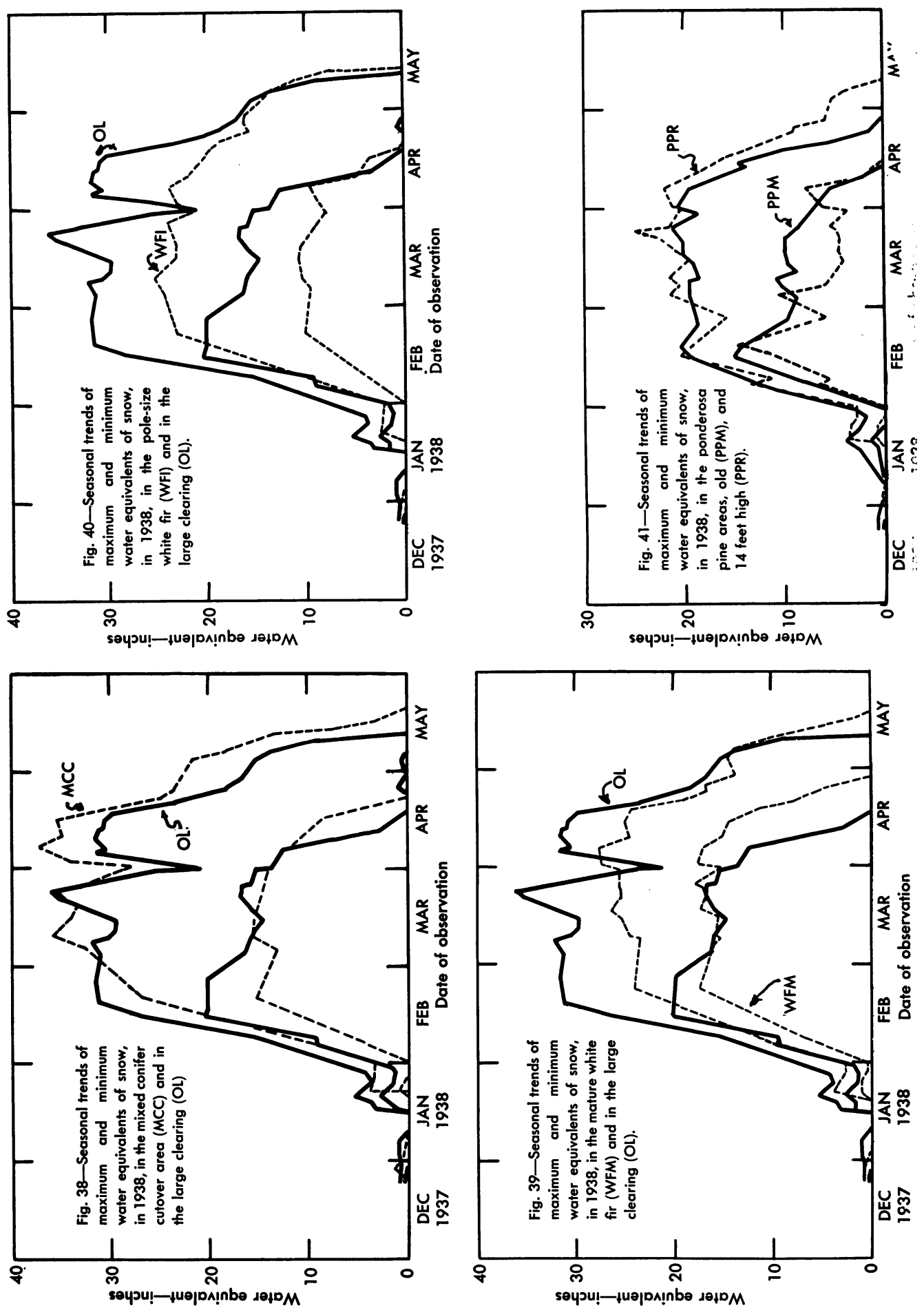
While the cutting in this mixed conifer stand was not planned for maximum accumulation of snow, it is undoubtedly true that larger openings, more uniformly distributed, would have increased the accumulation. This suggests the probable advantage of creating openings in the forest, by cutting and logging, to trap the maximum amounts of snow for storage and subsequent water

TABLE 13

SEASONAL MAXIMUMS OF TOTAL SNOW AT STATIONS OF MAXIMUM ACCUMULATION, BY FOREST TYPES AND SEASONS

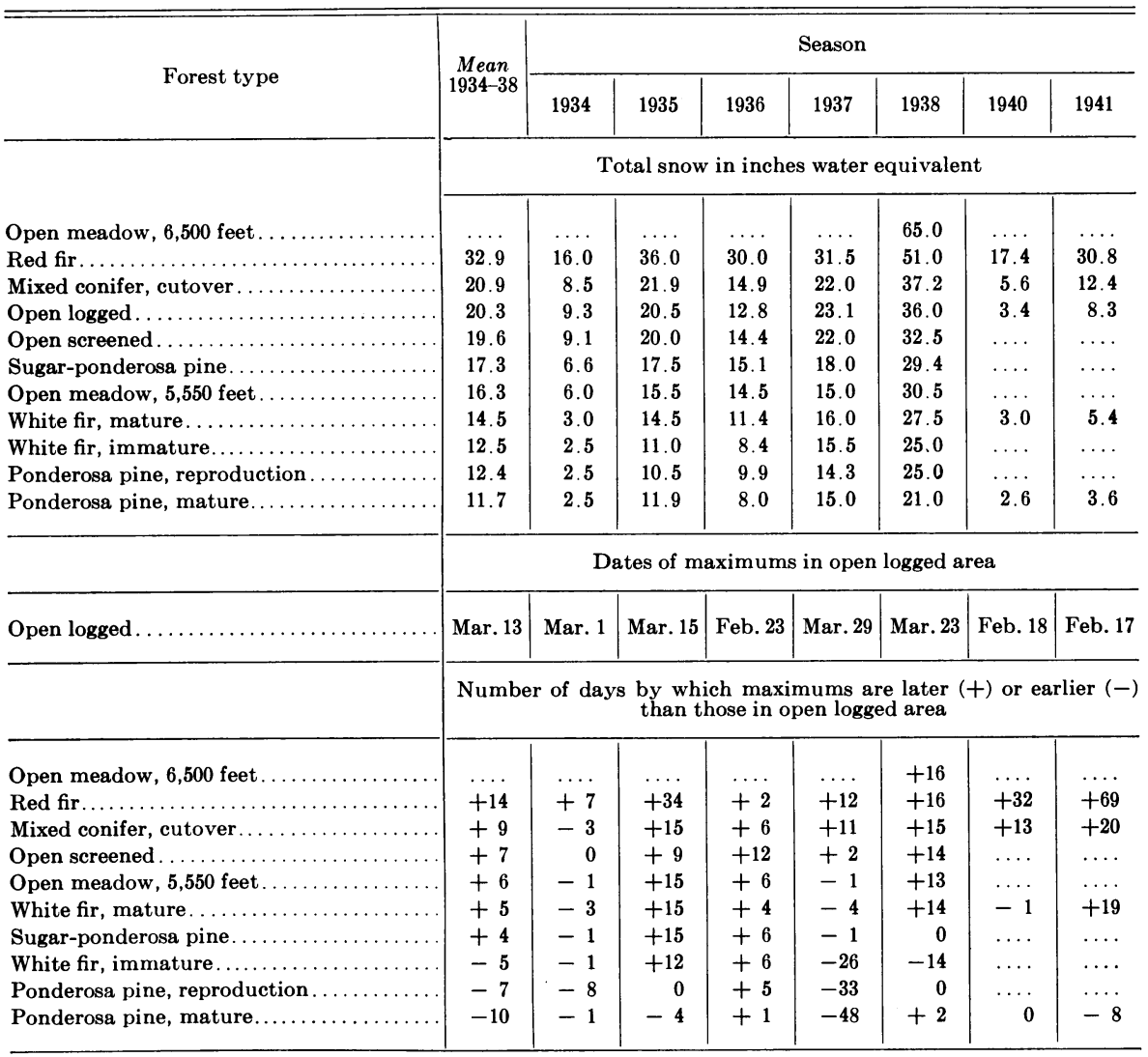

supply. The mixed conifer cutover stand resembled, roughly, the result of cutting in the old growth sugar pine-ponderosa pine stand. If such a comparison is justified, the cutting increased the storage of snow in openings by 3.6 inches water equivalent. It is significant that the gain by increased accumulation in the openings in a partially cut forest may more than compensate for the loss by interception of snowfall by the crowns of the trees. The greater density of the immature white fir forest doubtless accounts for the 2 inches less water equivalent of the snow as compared with that of the mature white fir. The excesses of accumulation in openings and the deficits under crowns, as compared with the large clearing (OL), are striking (figs. 42 and 43). 


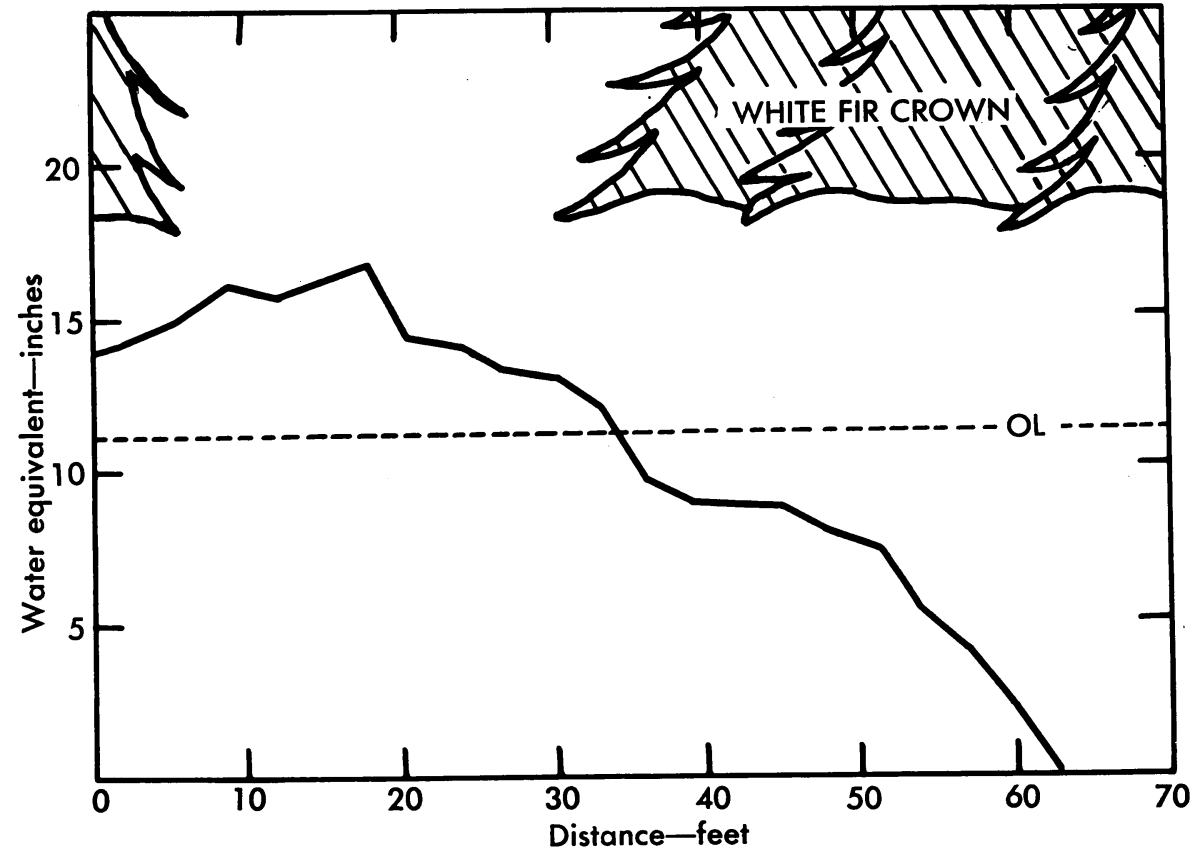

Fig. 42.-Profile of the water equivalents of the snow between stations 79 and 80 in the sugar pine-ponderosa pine area on April 4, 1937, compared with large clearing (OL).

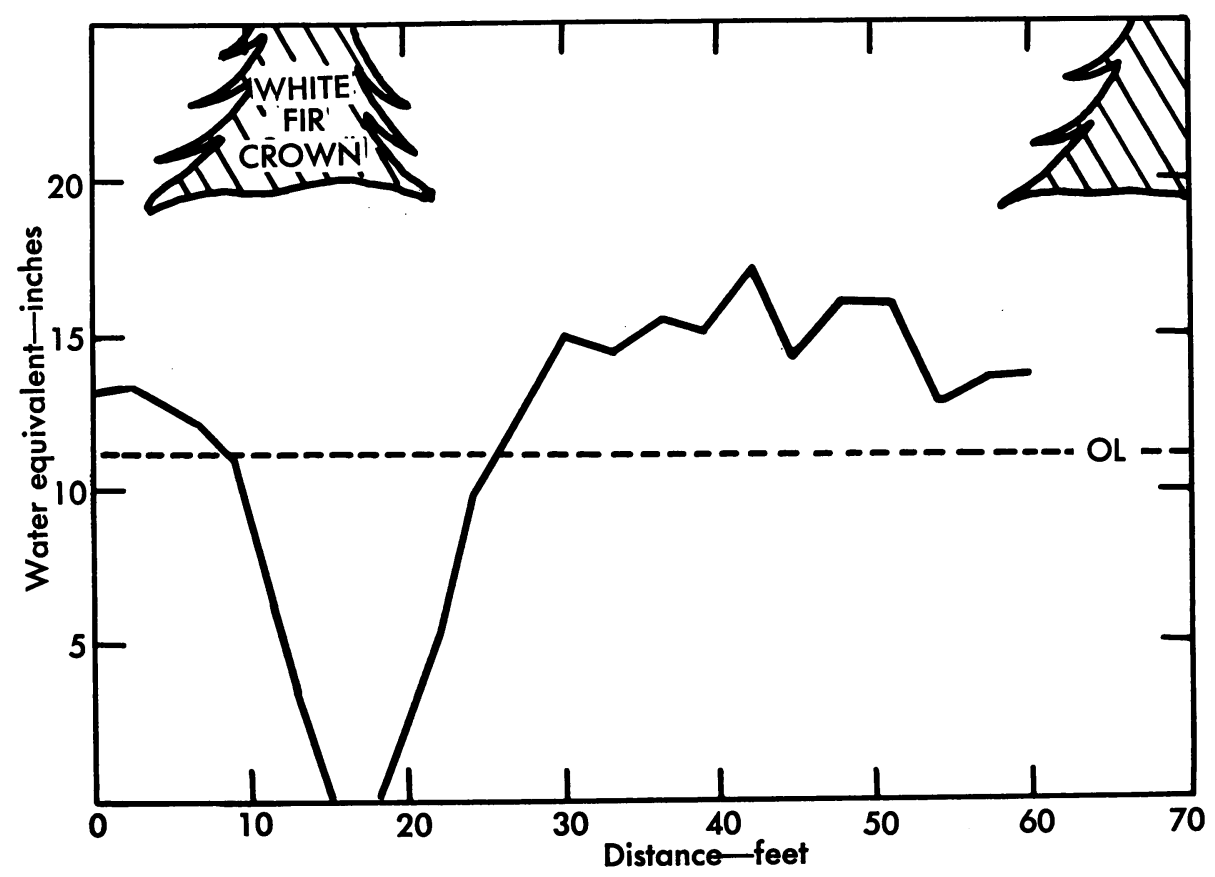

Fig. 43.-Profile of the water equivalents of the snow between stations 75 and 76 in the sugar pine-ponderosa pine area on April 4, 1937, compared with large clearing (OL). 
The seven seasons included both heavy and light snowfalls. There is a sharp contrast between about 30 inches water equivalent in the unusually heavy snowfall of 1938 and the 3 to 6 inches in the light years of 1934 and 1940. The differences between seasons are noticeable and, with minor exceptions, consistent in all of the forest types.

TABLE 14

SEASONAL MAXIMUMS OF TOTAL SNOW AT STATIONS OF MINIMUM ACCUMULATION, BY FOREST TYPES AND SEASONS

\begin{tabular}{|c|c|c|c|c|c|c|c|c|}
\hline \multirow{2}{*}{ Forest type } & \multirow{2}{*}{$\begin{array}{c}\text { Mean } \\
1934-38\end{array}$} & \multicolumn{7}{|c|}{ Season } \\
\hline & & 1934 & 1935 & 1936 & 1937 & 1938 & 1940 & 1941 \\
\hline & \multicolumn{8}{|c|}{ Total snow in inches water equivalent } \\
\hline Open meadow, 6,500 feet. & $\ldots$ & $\ldots$ & $\ldots$ & $\ldots$ & $\ldots$ & 52.0 & $\ldots$ & \\
\hline Red fir................ & 16.6 & 4.1 & 14.5 & 13.9 & 17.8 & 33.5 & 4.0 & 10.8 \\
\hline Open meadow, 5,550 feet. & 13.7 & 2.0 & 12.5 & 10.5 & 13.0 & 30.5 & $\ldots$ & $\ldots$ \\
\hline Open screened .......... & 12.8 & 3.6 & 11.0 & 9.9 & 14.0 & 25.4 & $\ldots$ & $\ldots$ \\
\hline Open logged ............. & 10.0 & 3.4 & 8.1 & 6.4 & 11.5 & .20 .5 & 2.8 & 4.3 \\
\hline White fir, mature........... & 7.9 & 0.9 & 6.5 & 4.0 & 10.0 & 17.9 & 1.5 & 0.7 \\
\hline Sugar-ponderosa pine $\ldots \ldots \ldots \ldots \ldots$ & 7.1 & 0.8 & 6.5 & 5.4 & 8.1 & 14.5 & $\ldots$ & $\ldots$ \\
\hline Ponderosa pine, reproduction....... & 7.1 & 1.1 & 6.5 & 2.3 & 10.5 & 15.0 & $\ldots$ & $\ldots$ \\
\hline Ponderosa pine, mature ........ & 7.0 & 1.0 & 5.5 & 3.1 & 10.5 & 15.0 & 1.1 & 1.1 \\
\hline Mixed conifer, cutover $\ldots \ldots \ldots \ldots \ldots \ldots$ & 6.8 & 2.3 & 5.0 & 1.8 & 9.5 & 15.5 & 1.4 & 0 \\
\hline \multirow[t]{2}{*}{ White fir, immature $\ldots \ldots \ldots \ldots \ldots \ldots \ldots$} & 4.8 & 1.0 & 4.0 & 1.3 & 7.0 & 10.8 & $\ldots$ & $\cdots$ \\
\hline & \multicolumn{8}{|c|}{ Dates of maximums in open logged area } \\
\hline \multirow[t]{2}{*}{ Open logged $\ldots \ldots \ldots \ldots \ldots \ldots \ldots \ldots \ldots$} & Feb. 10 & Mar. 1 & Jan. 18 & Feb. 17 & Feb. 4 & Feb. 15 & Feb. 18 & Jan. 31 \\
\hline & \multicolumn{8}{|c|}{$\begin{array}{c}\text { Number of days by which maximums are later }(+) \text { or earlier }(-) \\
\text { than those in open logged area }\end{array}$} \\
\hline Red fir............... & +49 & +24 & +90 & +17 & +59 & +53 & +30 & +73 \\
\hline Open meadow, 6,500 feet. . & $\ldots$ & $\ldots$ & $\ldots$ & $\ldots$ & $\ldots$ & +41 & $\ldots$ & $\ldots$ \\
\hline Open meadow, 5,550 feet. . & +26 & -2 & +69 & +12 & -1 & +52 & $\ldots$ & $\ldots$ \\
\hline Open screened .......... & +22 & +13 & +63 & +7 & -1 & +30 & $\ldots$ & $\cdots$ \\
\hline White fir, mature .......... & +9 & -4 & +3 & +8 & -1 & +39 & +2 & +1 \\
\hline White fir, immature $\ldots \ldots \ldots \ldots \ldots$ & +6 & -8 & +3 & +7 & -1 & +29 & $\ldots$ & $\ldots$ \\
\hline Mixed conifer, cutover................. & +4 & -10 & 0 & +8 & -3 & +23 & +1 & +37 \\
\hline Ponderosa pine, mature........ & +4 & +1 & +9 & +11 & -1 & +1 & 0 & +34 \\
\hline Ponderosa pine, reproduction.... & +3 & -9 & +6 & +7 & +9 & +4 & $\cdots$ & $\cdots$ \\
\hline Sugar-ponderosa pine $\ldots \ldots \ldots \ldots$ & +3 & -4 & +10 & +8 & -3 & +5 & $\ldots$ & $\ldots$ \\
\hline
\end{tabular}

The maximums of water equivalents at the stations of maximum accumulation in Table 13 were usually in openings between the crowns. The maximums of water equivalents at stations of minimum accumulation given in Table 14 are those recorded in most cases at stations under dense crowns. There are marked differences in the magnitudes for corresponding forest types and years. Usually, at the stations of minimum accumulation, the water equivalents are not more than half those at the stations of maximum accumulation. The differences between the values in the two tables represent, of course, the range of water equivalents for the different forest types at the dates when there was the most snow in storage. The types are arranged in descending 
order of mean water equivalent and, in general, the open areas had the most snow in storage and the immature white fir with the densest crown cover, the least. Low values in the ponderosa pine types probably reflect the more rapid melting on the southwest exposure under or between trees of less dense crowns.

The dates of maximum storage of snow water in each year are shown also in Tables 13 and 14 for the open logged area. In every season the maximums at the stations of minimum accumulation occur earlier than those at the stations of maximum accumulation. For the different forest types, the number of days by which the maximums are later or earlier than the dates in the open logged area are also shown. In most cases the maximums in the forest are found decidedly later than those in the open. The red fir shows the greatest retardation which reflects, in part, the higher elevation of that type. Among the forest types, the maximum at the station of minimum accumulation in the mature white fir came as much as 39 days later than that in the open logged. There are also noticeable seasonal differences associated with the amount and distribution of the snowfall. In 1938, with the heaviest snowfall, there was the greatest difference between maximum accumulation in the open. logged and in the forested areas. On the other hand, in 1934 and 1937, in most types, the maximums came a little earlier than in the open logged. Although there are too many exceptions to permit a general statement, the retardation of the maximums tends to be less at the stations of minimum accumulation than at those of maximum accumulation.

The influence of the forest on the accumulation and storage of snow has been suggested previously as an effect of the distribution of crowns and openings in any given area of a forest. As a quantitative expression of this effect, the crown densities or coverage, in per cent, for circular areas 20 feet in radius around each station were found to give usable linear relations for estimating the maximum water equivalents of the snow in the partially cut, mixed conifer stand and in three other types in certain years. The plotted trends shown in Figures 44 and 45 were different in different years except for 1935 and 1936 which were so close that the data were combined from the start. The equations by years are in the first column (below) where $d$ is depth water equivalent of the snow in inches and $c$ is percentage crown coverage.

All the regression coefficients were significant. When the differences between coefficients were tested, that between 1940 and 1934 was not significant

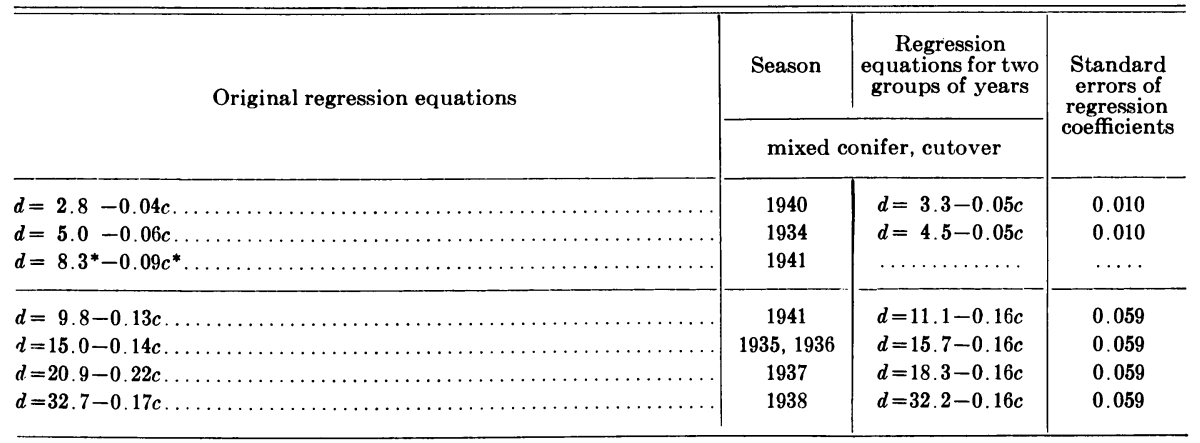

\footnotetext{
* Derived from 31 stations including 19 randomly located.
} 


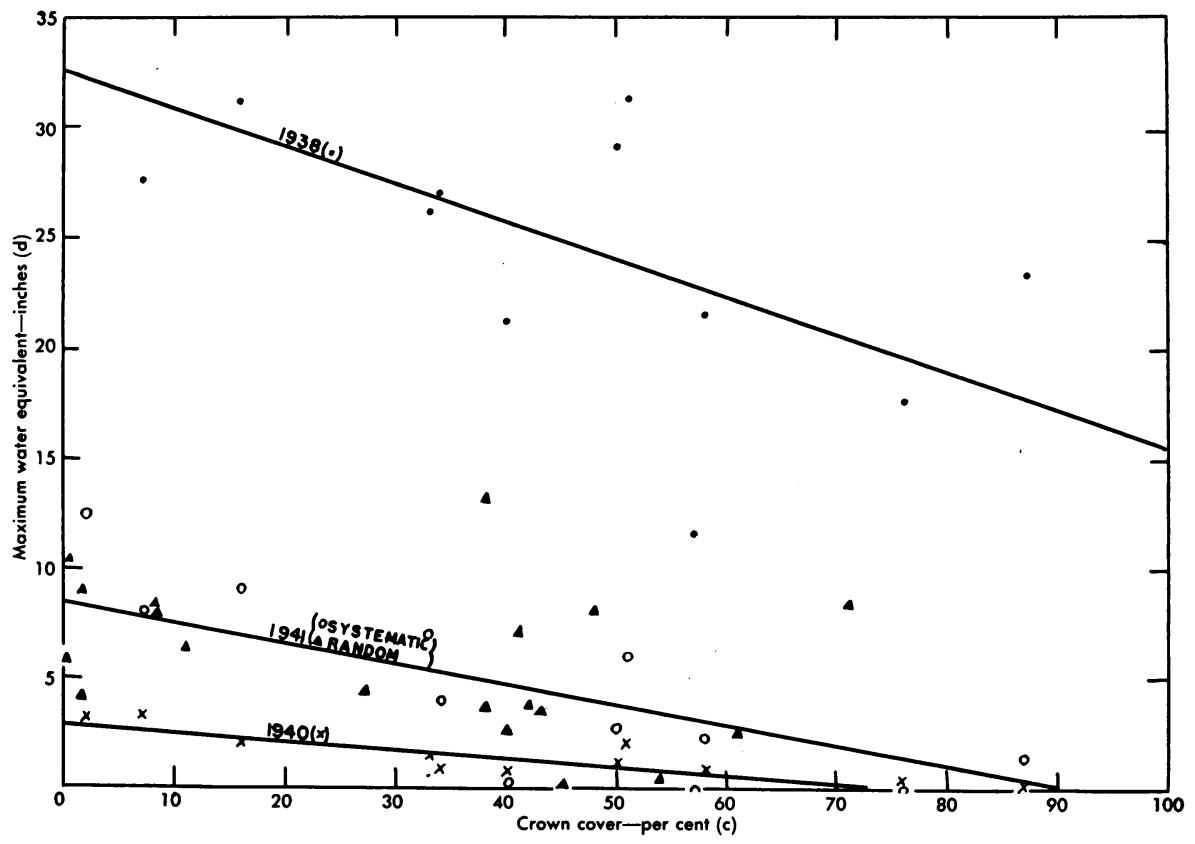

Fig. 44.-Relations of maximum water equivalents of snow (d) to percentage crown coverage $(c)$ in the mixed conifer cutover area in $1938(d=32.7-0.17 c), 1940(d=2.8-0.04 c)$, and $1941(d=8.3-0.09 c)$.

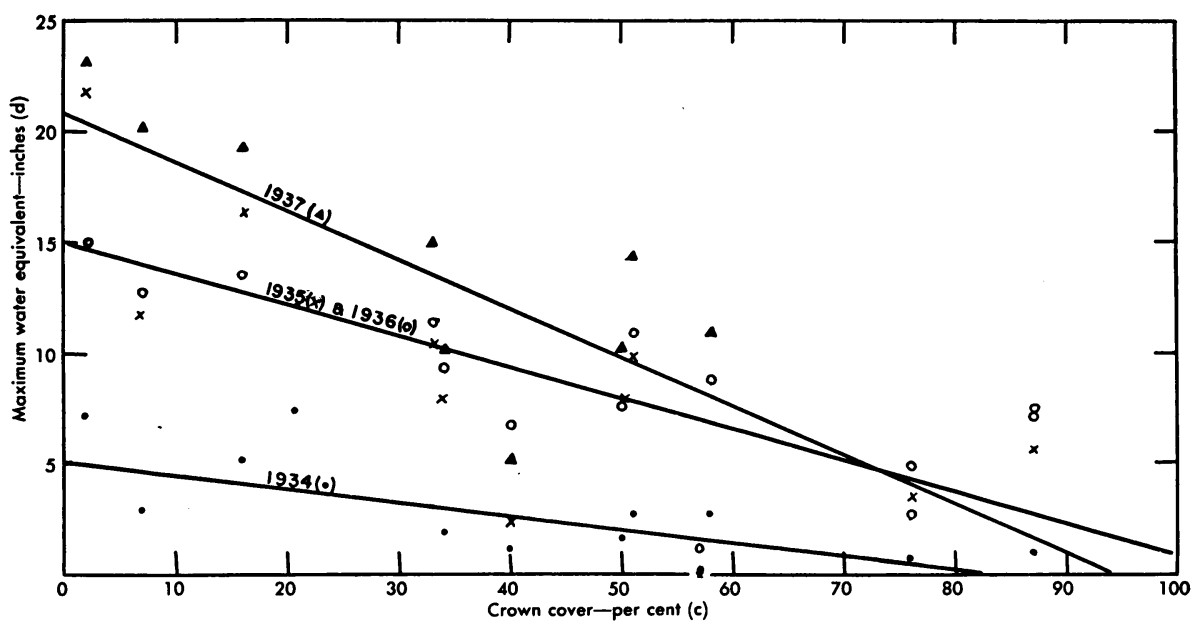

Fig. 45.-Relations of maximum water equivalents of snow (d) to percentage crown coverage $(c)$ in the mixed conifer cutover area in $1934(d=5.0-0.06 c), 1935-1936(d=15.0-$ $0.14 c)$, and $1937(d=20.9-0.22 c)$. 
nor were those between the other years, but between groups, the difference was significant. Hence the coefficients were combined into two groups, one for the years 1934 and 1940, with maximum water equivalents of less than 3 inches, and the other for the remaining years, with maximum water equivalents of more than 3 inches. When the equation for 1941 was computed from the 31 stations (including the 19 randomly located), the regression coefficient became 0.09 and was not significantly different from that of either group. The equations are given in the third column above. The $Y$-intercepts reflect the amount of snow in the different years. The regression coefficients may be interpreted, first, for the seasons of less than 3 inches water equivalent, by the statement that, for each increase of 10 per cent in crown coverage, the water equivalent would decrease by 0.5 inch. Similarly, for the seasons of heavy snow, the decrease in water equivalent would be 1.6 inches for each 10 per cent increase in crown coverage within a 20 -foot radius. For example, in a season of heavy snow, if the crown coverage were reduced from 80 to 30 per cent by silvicultural treatment, the maximum water equivalent would be increased by 8 inches. In a year of light snow, the increase would be 2.5 inches.

The data and trend lines are shown in Figures 46 to 48 , and the equations for different types, and comparisons between types for the same years, are given below in the few instances in which the coefficients were significant in types other than the cutover mixed conifer. Figures from the latter are repeated and a line for Douglas fir at the Wind River Experimental Forest in Washington (15) is added for comparison.

\begin{tabular}{|c|c|c|c|}
\hline Type & Year & $\begin{array}{l}\text { Regression } \\
\text { equations }\end{array}$ & $\begin{array}{l}\text { Standard } \\
\text { errors of } \\
\text { regression } \\
\text { coefficients }\end{array}$ \\
\hline Ponderosa pine, mature.... & 1934 & $d=1.6-0.05 c$ & 0.015 \\
\hline Mixed conifer, cutover.... & 1934 & $d=5.0-0.06 c$ & 0.016 \\
\hline Red fir $\ldots \ldots \ldots \ldots \ldots \ldots$ & 1934 & $d=14.5-0.11 c$ & 0.034 \\
\hline Ponderosa pine, mature.. & 1935 and 1936 & $d=7.2-0.10 c$ & 0.035 \\
\hline Mixed conifer, cutover... & 1935 and 1936 & $d=15.0-0.14 c$ & 0.029 \\
\hline Mixed conifer, cutover... & 1937 & $d=20.9-0.22 c$ & 0.052 \\
\hline White fir, mature ............. & 1937 & $d=20.0-0.14 c$ & 0.049 \\
\hline Douglas fir, Washington............. & March 22, 1950 & $d=27.0-0.10 c$ & $\ldots \ldots$ \\
\hline
\end{tabular}

None of the differences between coefficients of different types in the same years is significant, but it is suggestive that the cutover stand with relatively large openings between the trees tends to have larger regression coefficients than the uncut stands. This would mean that the openings created by cutting trap more snow, as the crown coverage is reduced by any desired percentage, than do the smaller openings of the uncut forest. On the other hand, for the same percentage coverage, the partially cut stand would have less snow in storage than the uncut white fir. Actually, however, the coverage is lower as a result of cutting, so that the cutover stand would usually have more snow. As examples, using the two equations for 1937, a cutting which reduced the crown cover from 70 to 40 per cent would result in increases of snow of 6.6 inches water equivalent in the cutover and of 4.2 inches in the uncut white fir. If both stands had 50 per cent coverage, the predicted water equivalent would 


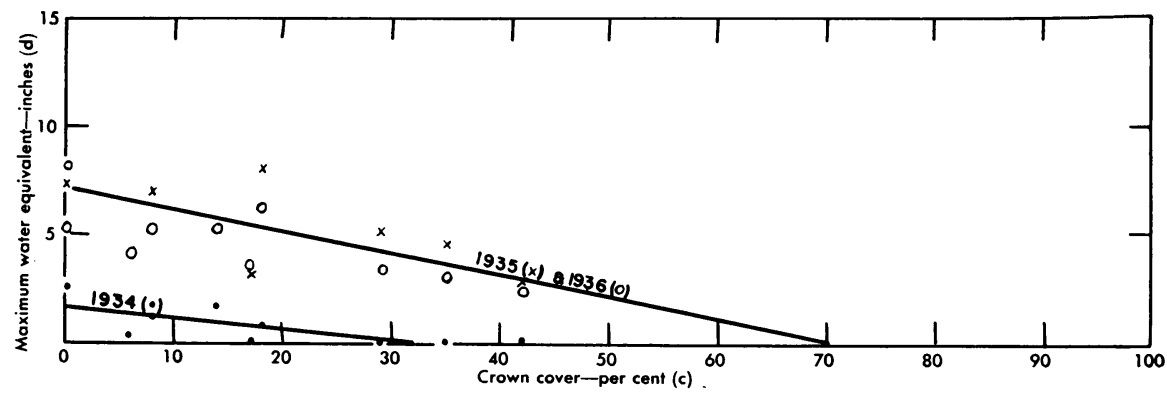

Fig. 46.-Relation of maximum water equivalents of snow (d) to percentage crown coverage (c) in old ponderosa pine in $1934(d=1.6-0.05 c)$, and 1935-1936 $(d=7.2-0.10 c)$.

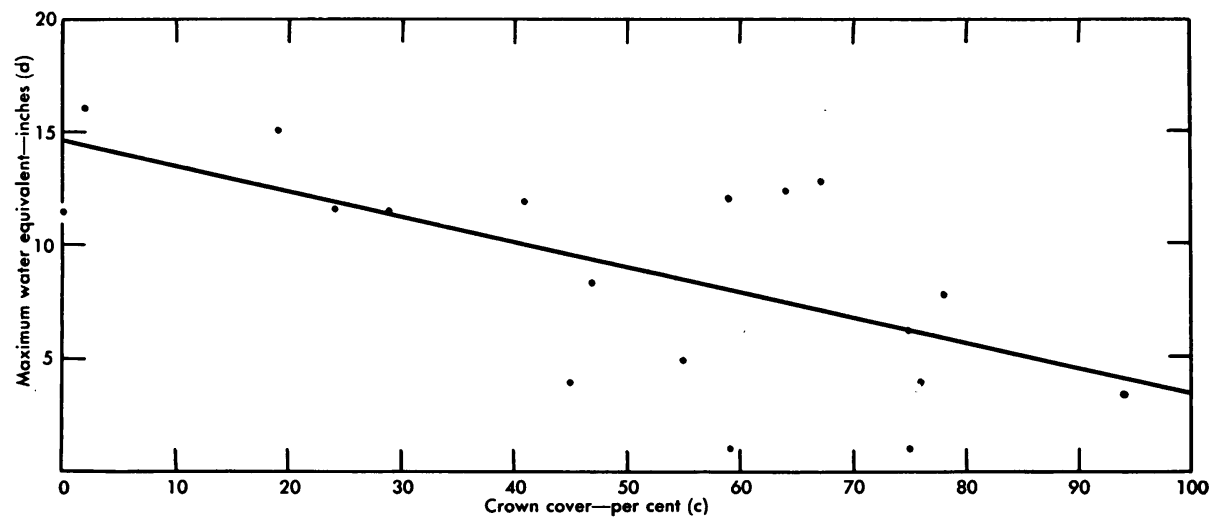

Fig. 47.-Relation of maximum water equivalent of snow (d) to percentage crown coverage (c) in the red fir in $1934(d=14.5-0.11 \mathrm{c})$.

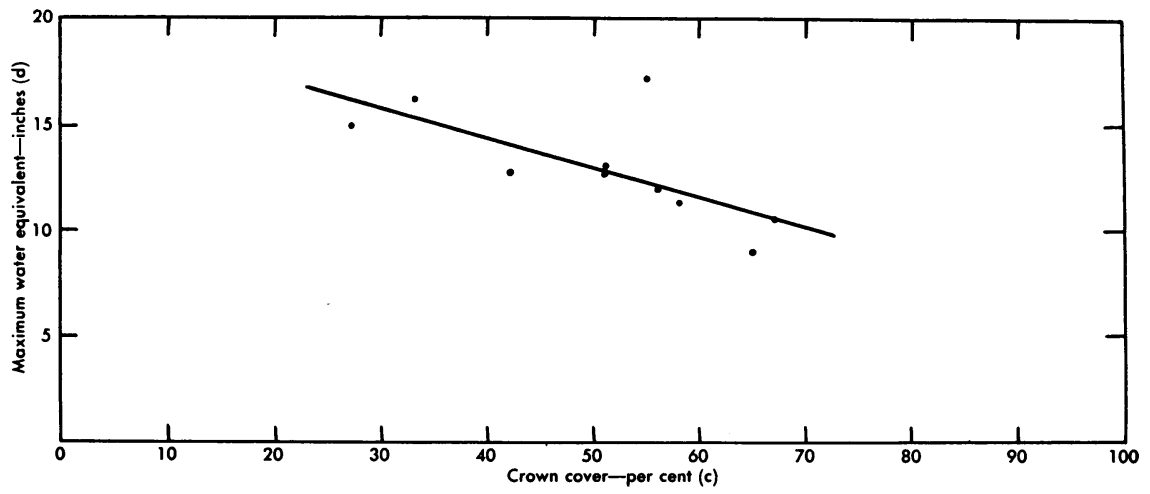

Fig. 48.-Relation of maximum water equivalent of snow (d) to percentage crown coverage (c) in the mature white fir in $1937(d=20.0-0.14 c)$. 
be 9.9 inches in the cutover and 13 inches in the uncut. If, however, the cutover had 40 per cent coverage and the uncut 70 per cent, then the predicted snow in storage would be 12.1 and 10.2 inches, respectively. The use of the equation for the white fir is perhaps questionable since it was the only one out of the seven seasons, in that type, that yielded a significant coefficient. The equation for Douglas fir also is based on too meager data for general use although the regression coefficient is close to those for the California types. The interesting point is that reducing the coverage by cutting tends to increase the storage of snow by important amounts.

The distribution of the snow in the forest in relation to crowns and openings, as shown by the profiles and by the records at different stations, is highly complex. The forest cover can be simply classified, from the maps of the crowns, as (1) under crowns and (2) in openings, and these classes are used in this study in several connections. However, this does not mean that snow areas of different characteristics necessarily correspond to these two classes. Not only is the area of excess snow usually greater than that of the openings, as indicated, but the areas of excess or deficit are commonly displaced in the direction of the snow-bearing winds, so that maximum water equivalents may be found well under the crowns, or minimums in the openings (figs. 49 and 50). Consequently, the comparisons and contrasts between crowns and openings, indicated at various points, are conservative as measures of the differences in the distribution of the snow.

As a supplement to the records of snow in the forested and open areas, one series of 10 stations was placed at the south side of the large clearing so that measurements of the snow were obtained close to the edge of the trees to the south and at distances up to 112 feet northward from the trees. Two profiles at 3-foot intervals, shown in Figures 51 and 52, add details of the distribution of the snow on specific dates. Incidentally, Figure 51 shows that "holes" in the snow occur around snags and stumps as well as around the stems under the crowns of living trees, and are, therefore, the result of some cause other than interception by the crowns. The stations can be combined into three groups according to distance from trees to the south. Three stations are 5 to 10 feet from trees, four are from 40 to 46 feet, and three are from 66 to 110 feet. The seasonal snowfall was almost the same at all three groups of stations, which means, incidentally, that drifts did not form to leeward of the trees, and there was no evidence of the excess accumulation found in the larger forest openings. Similarly, in January and February, when the snow had fallen recently, the differences between groups, in water equivalents of the total snow on the ground, were negligible. In the following tabulation, the mean water equivalents are shown for the three groups at different distances north of the trees in 1936, 1937, and 1938, and on three dates, the earliest shortly after snowfall, the second, at maximum accumulation of snow, and the third, the last time that there was snow at all stations.

At the two later dates in each year, the water equivalents are from 2 to 12 inches less at the 42 - and 85-foot distance than at the 8-foot. This is obviously the result of more rapid melting where the snow is not protected from sun and wind. There is little or no difference between the water equivalents at 42 and 85 feet. This indicates that the effect of these white firs, 20 to 50 feet high, does 
not extend as far as 42 feet although it is striking within 10 feet of the edges of the crowns. The profile of Figure 51 shows that the influence of the crowns extends at least to 20 feet and perhaps to 40 feet although it becomes progressively less with increasing distance from the trees.

\begin{tabular}{|c|c|c|c|}
\hline \multirow{3}{*}{ Date } & \multicolumn{3}{|c|}{ Average distance north of trees in feet } \\
\hline & 8 & 42 & 85 \\
\hline & \multicolumn{3}{|c|}{ Mean water equivalents in inches } \\
\hline 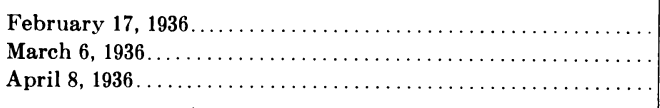 & $\begin{array}{r}10.5 \\
11.3 \\
6.6\end{array}$ & $\begin{array}{l}9.8 \\
9.4 \\
3.0\end{array}$ & $\begin{array}{r}10.2 \\
9.3 \\
2.2\end{array}$ \\
\hline 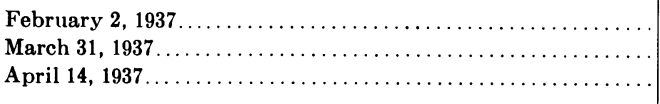 & $\begin{array}{l}15.6 \\
20.8 \\
18.2\end{array}$ & $\begin{array}{r}14.9 \\
12.5 \\
7.5\end{array}$ & $\begin{array}{r}14.3 \\
11.8 \\
7.0\end{array}$ \\
\hline 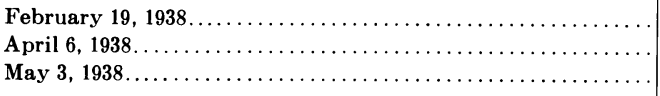 & $\begin{array}{l}24.8 \\
30.8 \\
20.0\end{array}$ & $\begin{array}{r}24.9 \\
26.2 \\
8.0\end{array}$ & $\begin{array}{l}25.6 \\
26.2 \\
10.4\end{array}$ \\
\hline
\end{tabular}

Figures based on crown coverage within 20 feet of points of sampling may or may not be representative of the water equivalents under stands of corresponding densities over larger areas. However, in the cutover mixed conifer stand the discrepancy was not large. Planimetered areas from crown maps gave the mean crown coverage of the 12 sampling circles as 42 per cent, and for the stand as a whole, a coverage of 37 per cent.

The complement of crown coverage-the sizes of openings between crownsis, however, conservative as a measure of the part of the forest area which may be expected to have an excess of stored snow. Measurements of the water equivalents of the snow at intervals of 3 feet along several profiles between stations indicated that the distances over which the snow storage exceeded that in the large clearing were from 1.0 to 1.7 times those of the openings between crowns in the white fir and sugar-ponderosa pine types (fig. 42). If the linear distances were converted to areas, the ratios would be larger. Using the one profile sample in the cutover mixed conifer, the ratio of distances was 1.20, while that for areas was 1.24 ; or, expressed in another way, the openings occupied 58 per cent of the area, while the area of excess snow covered 71 per cent. The generalization of these relations between openings and excess snow, for quantitative use, is not justified by the small number of samples that were taken.

However, in lodgepole pine 70 feet high, in Colorado, Wilm and Collet (37) reported a linear increase in water equivalent from a point 30 feet inward from the edge of the crowns to a point 30 feet outward from the edge which was the radius of the maximum openings between crowns. In this 60 feet, the water equivalents increased from 5 to 9 inches. The relation can be expressed as $d=7+1 / 15 l$, where $d$ is inches depth water equivalent and $l$ is the distance in feet, outward (+) or inward (-) from the edge of the crown as $O$. 


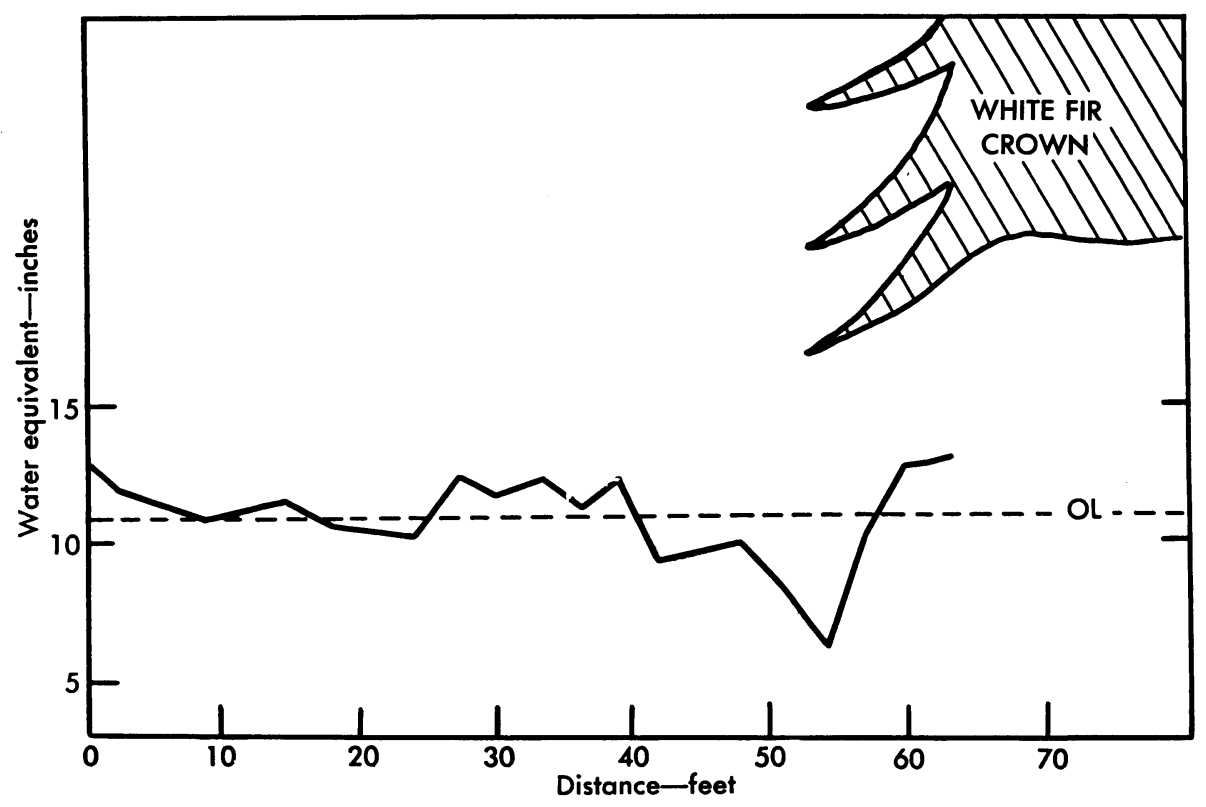

Fig. 49.-Profile of the water equivalents of the snow from northeast to southwest in the mature white fir compared with the large clearing (OL) on April 6, 1937.

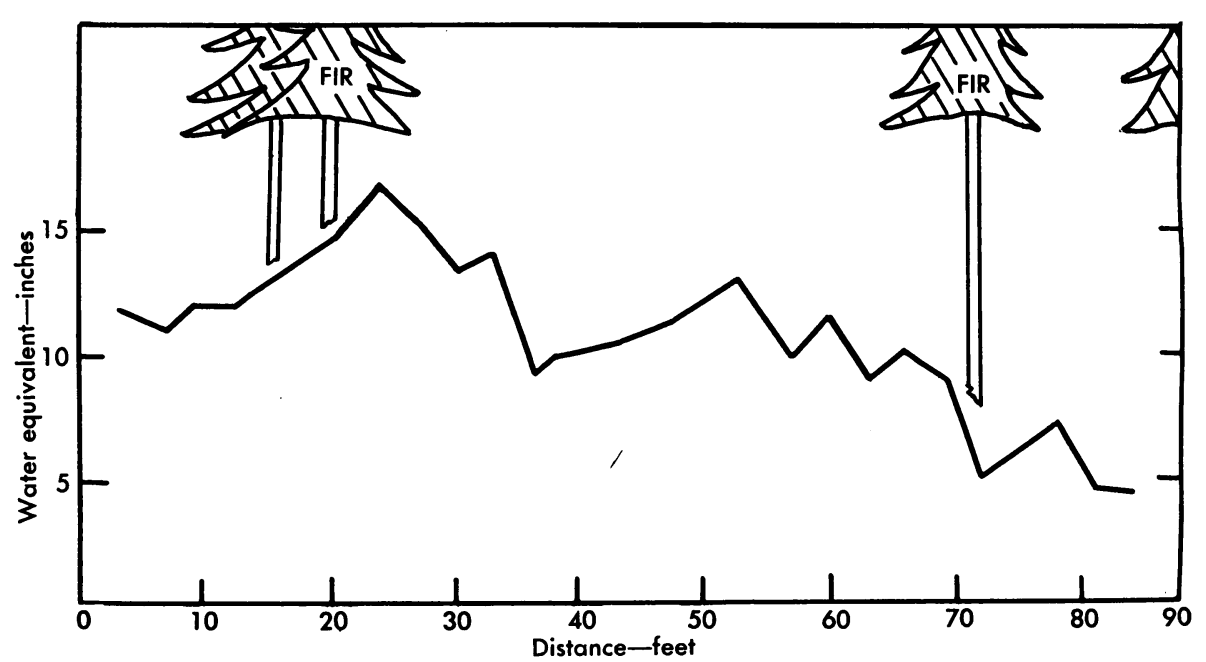

Fig. 50.-Profile of the water equivalents of the snow from southeast to northwest in the red fir on March 19, 1940. 


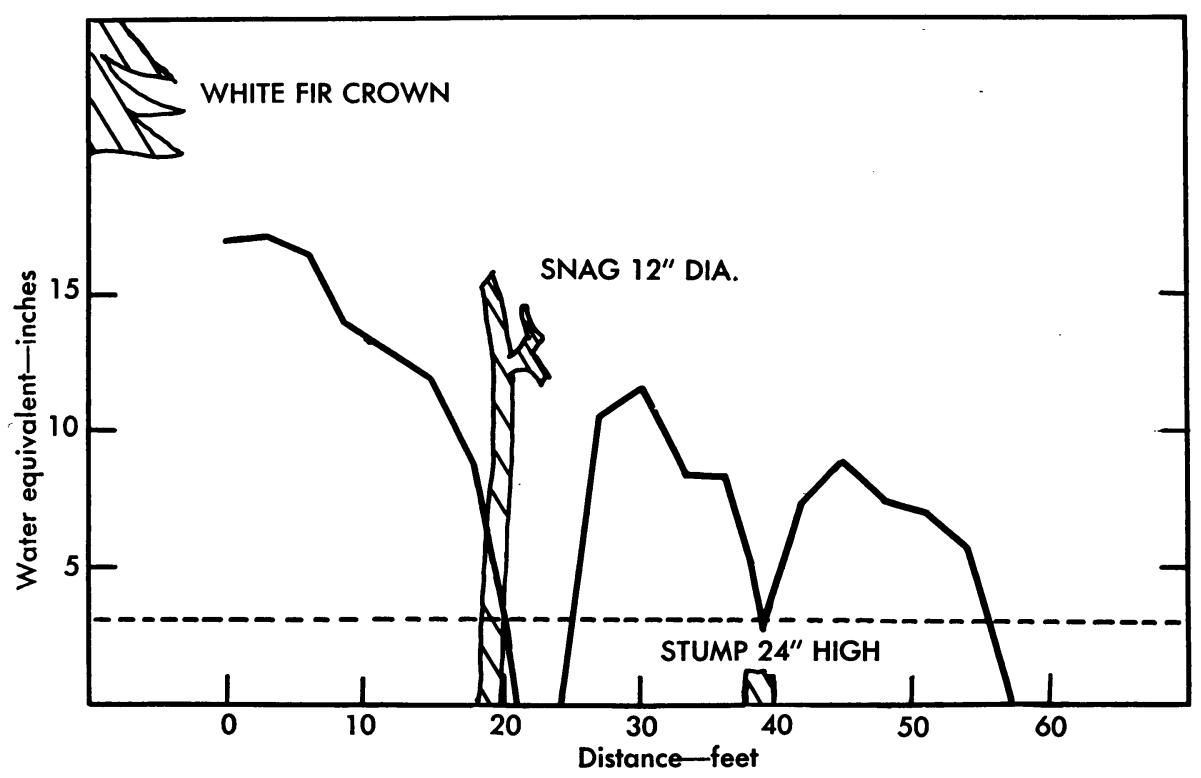

Fig. 51.-Profile of the water equivalents of the snow from south to north in the open screened area compared with the large clearing (OL) on April 18, 1937.

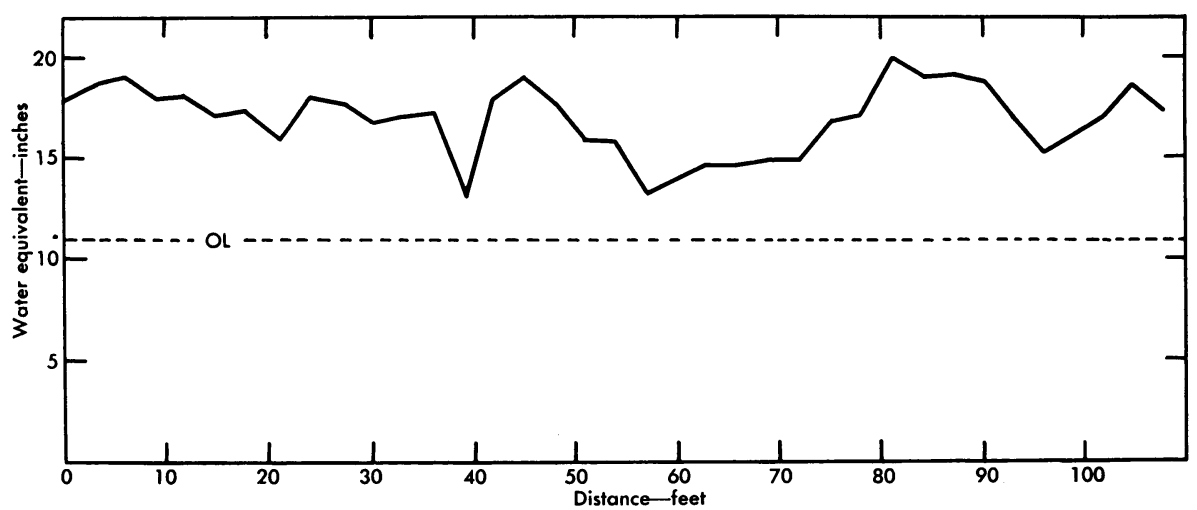

Fig. 52.-Profile of the water equivalents of the snow from south to north in the open screened area compared with the large clearing (OL) on April 4, 1937. 
In the same locality, thinnings in sapling stands of lodgepole pine resulted in increases of 0.95 and 1.33 inches water equivalent. Larger increases were obtained by cuttings in mature stands of Engelmann spruce and alpine fir. Sixty per cent of the merchantable volume of timber was removed under each of three systems of cutting, with the following increases in water equivalent as compared with the uncut area (29).

\begin{tabular}{|c|c|}
\hline System of cutting & $\begin{array}{c}\text { Increased } \\
\text { water } \\
\text { equivalent }\end{array}$ \\
\hline Alternate clear-cut strips 66 feet wide.... & $\begin{array}{c}\text { inches } \\
2.46\end{array}$ \\
\hline Single-tree selection of mature trees................. & 2.63 \\
\hline Clear-cut groups 66 feet in diameter $\ldots \ldots \ldots \ldots \ldots \ldots \ldots \ldots$ & 3.14 \\
\hline
\end{tabular}

The width of strips or groups was about equal to the height of the trees-the size indicated as most favorable for trapping snow, in an earlier study by Niederhof and Dunford (25).

The influence of the forest is also expressed in Table 15, which shows the differences between mean water equivalents of the snow, at stations under the crowns and at those in the openings, on the dates of maximum accumulation, by forest types and seasons. With minor exceptions, the water equivalents in the openings are noticeably greater than those under the crowns. The maximum difference is 8.2 inches in the immature white fir in 1938. Many of the differences are statistically significant, particularly in the mixed conifer cutover, sugar pine-ponderosa pine, and red fir, where some of the openings between the trees were quite large. The mean differences for all seasons are from 1 to 5 inches. Again the evidence is quite clear that creating openings in the forest by cutting may be expected to increase the storage of snow.

Evaporation from Snow.-Evaporation is generally considered one of the main causes of water loss from snow on the ground. The term evaporation, as used here, means the net result of the exchange of molecules of water between snow and air. Studies of evaporation from snow by Church (6), on the east slope of the Sierra Nevada, by Croft (10), in the Wasatch Mountains in Utah, by Wilm, Garstka, Goodell, and others $(38,26)$, near the headwaters of the Colorado River and in the East, have shown losses by evaporation from 0.016 to 0.085 inches of water per day. According to Rowe (27), at North Fork, California, however, loss by evaporation was very small because it was nearly balanced by gains from condensation. The outstanding characteristic of the evaporation studies in the present work on the west slope of the Sierra Nevada is the small magnitude of the measured losses. The explanation is probably to be found in the geographic and physiographic location on the west-facing slopes of the mountains which are exposed to the moisture-bearing winds from the Pacific Ocean. Thus the humidity of the atmosphere is high, and the vapor pressure difference between snow surface and air above tends to be low or negative; consequently the evaporation is also low.

The question has been raised as to whether it is possible to obtain a reliable measure of evaporation from snow by the use of any container in view of 
TABLE 15

MEAN WATER EQUIVALENTS OF SNOW UNDER CROWNS (U) AND IN OPENINGS (O), AT DATES OF MAXIMUM ACCUMULATION, BY FOREST TYPES AND YEARS

\begin{tabular}{|c|c|c|c|c|c|c|c|c|c|c|c|}
\hline Season & $\begin{array}{l}\text { Crown } \\
\text { cover }\end{array}$ & RF & MCC & OL & $\underset{5,550 \text { ft. }}{O M}$ at & OS & SP-PP & WFM & WFI & PPR & PPM \\
\hline & & & & & Wate & equival & lent in in & ches & & & \\
\hline \multirow[t]{3}{*}{1934} & $\mathrm{U}$ & 6.5 & $1.1 \ddagger$ & $\ldots$ & $\ldots$ & $7.9 \|$ & 0.7 & 1.4 & 0.3 & 1.2 & 0.2 \\
\hline & 0 & 11.1 & 4.0 & 3.1 & 3.2 & 4.79 & 2.9 & 1.9 & 1.3 & 2.3 & 1.3 \\
\hline & $\mathrm{O}-\mathrm{U}$ & $4.6^{*}$ & $2.9^{*}$ & $\ldots$ & $\ldots$ & $\ldots$ & $2.2^{*}$ & 0.5 & $1.0^{*}$ & $1.1^{*}$ & $1.1^{*}$ \\
\hline \multirow[t]{3}{*}{1935.} & $\mathbf{U}$ & $20.9 \S$ & 6.7 & $\ldots$ & $\ldots$ & $17.6 \|$ & 6.1 & 9.7 & 6.3 & $4.6 \ddagger$ & $3.4 \ddagger$ \\
\hline & 0 & 24.4 & 12.7 & 12.0 & 13.2 & 13.89 & 10.2 & 9.9 & 8.9 & 8.3 & 6.4 \\
\hline & $\mathrm{O}-\mathrm{U}$ & $3.5^{*}$ & $6.0^{*}$ & $\ldots$ & $\ldots$ & $\ldots$ & $4.1^{*}$ & 0.2 & $2.6^{*}$ & $3.7^{*}$ & $3.0^{*}$ \\
\hline \multirow[t]{3}{*}{$1936 \ldots$} & $\mathrm{U}$ & $19.1 \ddagger$ & 6.8 & $\ldots$ & $\ldots$ & $11.4 \|$ & 6.2 & 6.1 & 3.2 & 4.3 & 3.3 \\
\hline & 0 & 23.4 & 11.3 & 8.8 & 12.4 & 10.89 & 10.4 & 6.0 & 5.1 & 7.4 & 5.4 \\
\hline & $\mathrm{O}-\mathrm{U}$ & $4.3^{*}$ & 4. $5^{*}$ & $\ldots$ & $\ldots$ & $\ldots$ & $4.2^{*}$ & -0.1 & 1.9 & $3.1^{*}$ & $2.1^{*}$ \\
\hline \multirow[t]{3}{*}{$1937 \ldots \ldots \ldots \ldots$} & $\mathrm{U}$ & $23.5 \ddagger$ & 7.4 & $\ldots$ & $\ldots$ & $21.4 \|$ & $6.7 \ddagger$ & 12.2 & 8.5 & 11.6 & 12.1 \\
\hline & 0 & 25.1 & 15.6 & 14.7 & 14.0 & 14.39 & 11.5 & 14.3 & 12.8 & 11.6 & 11.4 \\
\hline & $\mathrm{O}-\mathrm{U}$ & 1.6 & $8.2^{*}$ & $\ldots$ & $\ldots$ & $\ldots$ & $4.8^{*}$ & 2.1 & $4.3^{*}$ & 0 & -0.7 \\
\hline \multirow[t]{3}{*}{1938.} & $\mathrm{U}$ & $39.7 \S$ & $23.3 \$$ & $\ldots$ & $\ldots$ & $30.8 \|$ & $18.6 \ddagger$ & 21.5 & 15.7 & $14.2 \ddagger$ & $13.4 \S$ \\
\hline & O & 41.7 & 27.3 & 25.7 & $30.4 \dagger$ & 25.79 & 23.0 & 23.0 & 23.9 & 18.5 & 16.5 \\
\hline & $\mathrm{O}-\mathrm{U}$ & $2.0^{*}$ & $4.0^{*}$ & $\ldots$ & $\ldots$ & $\ldots$ & $4.4^{*}$ & 1.5 & $8.2^{*}$ & $4.3^{*}$ & $3.1^{*}$ \\
\hline \multirow[t]{3}{*}{$1940 .}$. & $\mathrm{U}$ & 8.2 & $1.4 \ddagger$ & $\ldots$ & $\ldots$ & $\ldots$ & $\ldots$ & 2.2 & $\ldots$ & $\ldots$ & 1.9 \\
\hline & $\mathrm{O}$ & 11.0 & 2.1 & 3.1 & $\ldots$ & $\ldots$ & $\ldots$ & 2.1 & $\ldots$ & $\ldots$ & 2.0 \\
\hline & $\mathrm{O}-\mathrm{U}$ & $2.8^{*}$ & $0.7^{*}$ & $\ldots$ & $\ldots$ & $\ldots$ & $\ldots$ & -0.1 & $\ldots$ & $\ldots$ & 0.1 \\
\hline \multirow[t]{3}{*}{1941.} & $\mathbf{U}$ & $15.6 \ddagger$ & 3.6 & $\ldots$ & $\ldots$ & $\ldots$ & $\ldots$ & 2.8 & $\ldots$ & $\ldots$ & 2.3 \\
\hline & 0 & 19.5 & 6.7 & 5.9 & $\ldots$ & $\ldots$ & $\ldots$ & 2.7 & $\ldots$ & $\ldots$ & 2.7 \\
\hline & $\mathrm{O}-\mathrm{U}$ & $3.9^{*}$ & $3.1^{*}$ & $\ldots$ & $\ldots$ & $\ldots$ & $\ldots$ & -0.1 & $\ldots$ & $\ldots$ & 0.4 \\
\hline \multirow[t]{2}{*}{ Mean 1934-38. } & $\mathbf{U}$ & 21.9 & 9.1 & $\ldots$ & $\ldots$ & $17.8 \|$ & 7.7 & 10.2 & 6.8 & 7.2 & 6.5 \\
\hline & 0 & 25.1 & 14.2 & 12.9 & 14.6 & 13.99 & 11.6 & 11.0 & 10.4 & 9.6 & 8.2 \\
\hline \multirow[t]{2}{*}{$1934-41 \ldots \ldots \ldots$} & $\mathbf{U}$ & 19.1 & 7.2 & $\ldots$ & $\ldots$ & $\ldots$ & $\ldots$ & 8.0 & $\ldots$ & $\ldots$ & 5.2 \\
\hline & $\mathrm{O}$ & 22.3 & 11.4 & 10.5 & & $\ldots$ & $\ldots$ & 8.6 & $\ldots$ & $\ldots$ & 6.5 \\
\hline
\end{tabular}

* Difference is significant.

t Only one station.

+ Two highest days used as basis.

Three highest days used as basis.

Three stations within 8 feet of crowns to south.

Four stations, 40 feet or more from any crown.

the fact that solar radiation penetrates 5 inches or more through the snow and thus tends to heat the walls of the container. This heat would be transmitted to the snow in the container and would obviously accelerate melting. However, the temperature of the snow will not go above $32^{\circ} \mathrm{F}$ so long as the snow remains in the form of snow. If the temperature of the snow is the same inside and outside of the container, the vapor pressure will also be the same. If the humidity or temperature of the air above the snow in the container changes, a change in vapor pressure results. It seems unlikely that the narrow edge of a pan coated with aluminum paint and exposed above the snow only part of the time would cause more than a small change. 
Temperature of the snow, recorded between 8:00 A.M. and 5:00 P.M., at 3 inches below the surface, was $32^{\circ} \mathrm{F}$ during periods of melting, which included the hours when the sun was high on many days in the winter. When air temperature fell below freezing, snow temperature tended to follow, but the relationship is not sufficiently close to be useful in estimating snow temperature on the basis of air temperature. The relation in the range below $32^{\circ} \mathrm{F}$ was roughly one of equality with the mean daily air temperature, as reported also in Switzerland (1). Dispersion of the points was a little less wide when the air temperature was plotted the day before that of the snow. With few exceptions, the snow temperatures were higher than the daily minimum and lower than the daily maximum air temperatures although, again, useful correlations were not found. The minimum snow temperature recorded was $0^{\circ} \mathrm{F}$, once when the air temperatures of the two preceding nights were $-15^{\circ}$ and $-8^{\circ}$ and again when they were $3^{\circ}$ and $0^{\circ}$ following 4 nights of subzero air temperatures. In New York, when air temperatures were below $32^{\circ}$, the snow surface temperatures averaged 3 to 4 degrees higher than the air temperatures. Snow temperature may increase from the surface downward by as much as 10 degrees per foot of depth (20).

No useable relations were found between evaporation or condensation and either snow temperatures or the differences between snow and air temperatures.

TABLE 16

MEAN MONTHLY CLIMATIC DATA* AND COMPUTED EVAPORATION $\dagger$ FOR SEASON OF 1935, IN OPENING IN MATURE PONDEROSA PINE

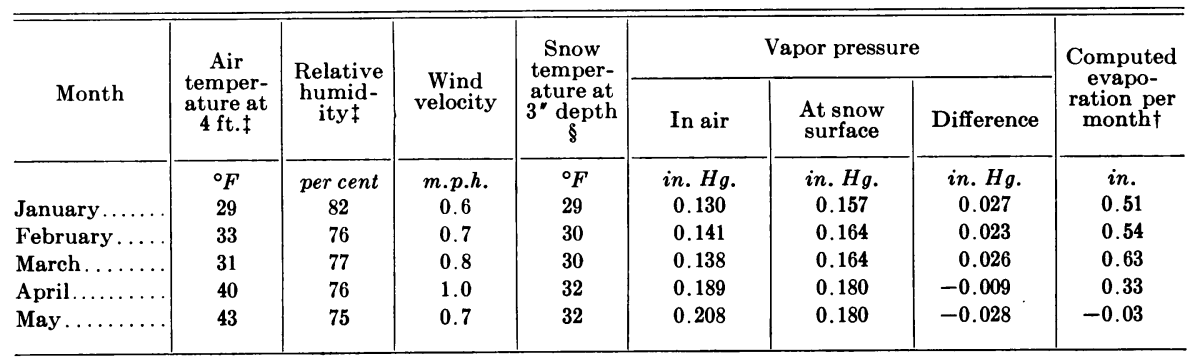

* Made available through the courtesy of the California Forest and Range Experiment Station, U. S. Forest Service.

t Using Horton's formula for a free water surface in a Weather Bureau pan.

Means of hourly readings from hygrothermograph charts.

Temperature at surface would be less than 1 degree lower.

As the season advances in the spring, air temperatures become warmer, but the surface temperature of the snow does not go above $32^{\circ} \mathrm{F}$. Thus the vapor pressure difference becomes smaller later in the spring and may be reversed so that the gradient is toward, rather than away from, the snow surface. The climatic data and the evaporation computed by Horton's formula (18), as shown in Table 16, confirm this for March, April, and May. The computed evaporation in inches per month is 0.6 for March, 0.3 for April, and -0.03 for May when condensation exceeded evaporation. The trends for the measured evaporation in inches of water per month, for individual forest types, given in Table 17, are not consistent, but when the 
medians for all types are used, the evaporation from March to June shows a similar decrease-from 0.20 in March to 0.15 in April to 0.04 in Maywith condensation of 0.17 in June. If this trend during the spring is correct, it means that losses from the snow by evaporation become smaller and may even become gains as condensation increases toward the end of the snow season. This possibility may contradict the frequent suggestion that evaporation losses increase as the snow lasts longer into the spring or summer. The steeper downward trend of monthly evaporation from 2.8 inches in

TABLE 17

MEDIAN RATES OF MONTHLY EVAPORATION FROM SNOW, BY MONTHS AND FOREST TYPES, BASED ON SEVEN YEARS OF RECORDS

\begin{tabular}{|c|c|c|c|c|c|c|c|c|}
\hline \multirow[b]{2}{*}{ Forest type } & \multicolumn{8}{|c|}{ Evaporation, depth of water in inches } \\
\hline & Dec. & Jan. & Feb. & Mar. & April & May & June & $\begin{array}{c}\text { Seasonal } \\
\text { total }\end{array}$ \\
\hline Large opening near river. . & 0.005 & 0.002 & 0.001 & 0.002 & 0.002 & $-0.001^{*}$ & $\ldots$ & 0.01 \\
\hline Sugar-ponderosa pine..... & 0.09 & 0.30 & -0.28 & 0.05 & 0.31 & 0.25 & $\ldots$ & 0.72 \\
\hline White fir, immature...... & $\ldots$ & 0.13 & 0.18 & 0.33 & 0.07 & 0.09 & $\ldots$ & 0.80 \\
\hline Ponderosa pine, $14 \mathrm{ft}$. high & $\ldots$ & 0.16 & 0.15 & 0.20 & 0.14 & 0.21 & & 0.86 \\
\hline Open screened $\ldots \ldots \ldots \ldots$ & -0.02 & 0.02 & 0.21 & 0.22 & 0.39 & 0.05 & & 0.87 \\
\hline White fir, mature........ & $\ldots$ & 0.15 & 0.18 & 0.30 & 0.20 & 0.24 & $\ldots$ & 1.07 \\
\hline Medians, all types........ & 0.01 & 0.07 & 0.12 & 0.20 & 0.15 & 0.04 & $-0.17 \rightarrow$ & $0.42 \dagger$ \\
\hline
\end{tabular}

* Minus signs indicate excess of condensation over evaporation.

+ If the -0.17 for June is omitted, the total for the other months becomes 0.59 . The median of the seasonal totals of the different types is 0.86 .

January to 0 in June, from the uniformly cold water of Lake Superior, is an example of a similar phenomenon (41, p. 147).

The comparisons between different types and densities of cover for any one month (table 17) are not consistent. When the values for the individual months are totaled for the season, they show a wide range. The types are arranged in ascending order of magnitude of these seasonal totals. The red fir and the large opening on a terrace only a few feet above the river have the lowest values. Presumably these two types had the highest atmospheric humidities and, consequently, the lowest vapor pressure differences. At the high end of the series, the mixed conifer cutover with the largest proportion of sizable openings between the trees had the highest value-1.46 inches for the season. The open logged area was almost as high, and the open meadow, third. The dense stand of immature white fir and the young thicket of ponderosa pine had nearly the same evaporation notwithstanding their different characteristics. The most important conclusion from these figures is that evaporation losses from the snow, under any conditions of cover, are surprisingly low-less than $1 \frac{1}{2}$ inches for the season and less than $1 / 2$ inch in any one month. 
To the extent that solar radiation penetrated the snow, thus heating the sides and bottoms of the pans, evaporation would presumably be increased. If that were the case, the figures for evaporation would be too large. But it seems unlikely that there can be any large error in this direction in figures that are consistently lower than those reported elsewhere. What effect the pans containing the snow might have on the outgoing radiation and conden-

TABLE 18

MEDIAN EVAPORATION FROM SNOW IN LARGE OPENINGS DURING 10-HOUR DAYS AND 14-HOUR NIGHTS, BY SEASONS

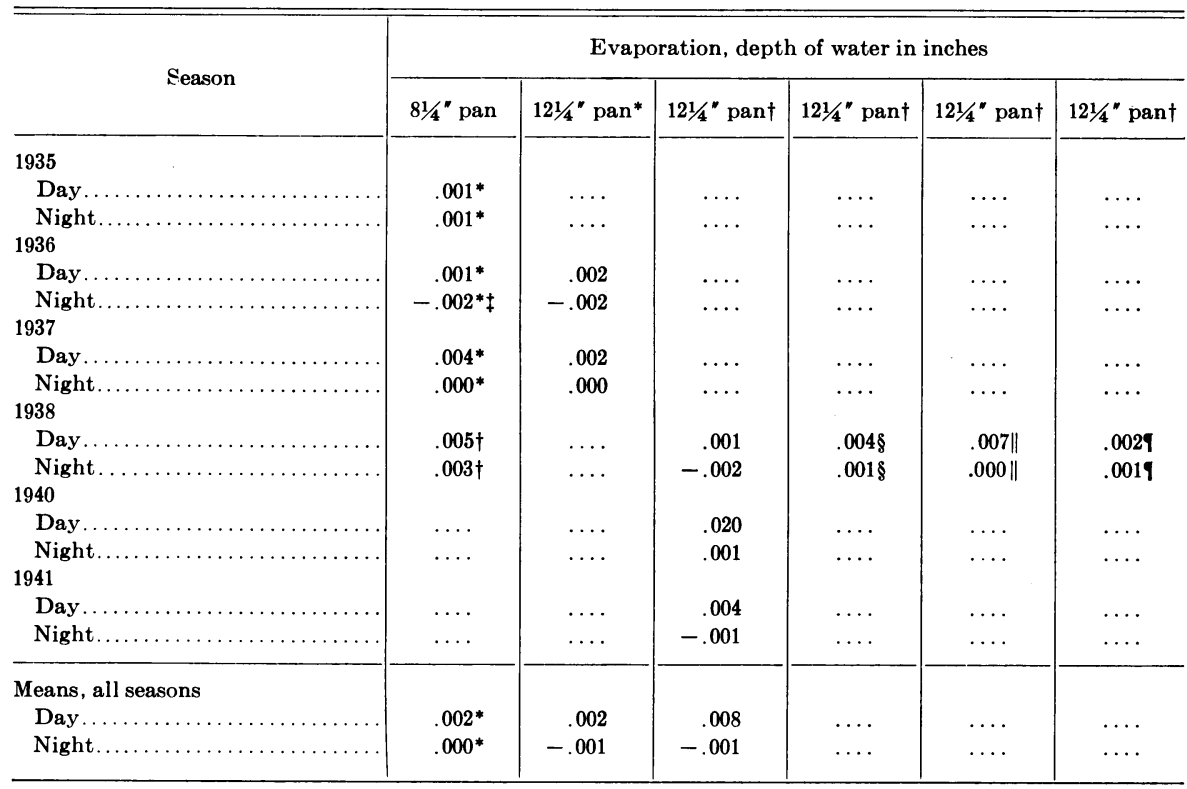

* On low terrace close to river on south side.

+ On bench 30 feet above river on north side.

$\ddagger$ Minus signs indicate condensation in excess of evaporation.

Pan without roof; periods without precipitation.

Pan under roof; periods without precipitation.

I Pan under roof; periods with precipitation.

sation or evaporation during the night is not obvious. Condensation tends to exceed evaporation at night, but the amounts are usually small, and again it seems unlikely that the containers cause any large errors in the totals for net evaporation.

The records of evaporation at the stations in the large opening near the river were made both morning and night each day so that the nocturnal and diurnal amounts could be separately compiled as in Table 18. In all but one of the comparisons the evaporation during the night is less than that during the day. In several seasons, condensation exceeded evaporation during the night periods although the medians for any one season were not greater than 0.002 inch of condensation for a 14-hour night period.

During the early years of the study, pans $81 / 4$ inches in diameter were used, and later, 121/4-inch ones. In 1936, 1937, and 1938, both sizes were used 
at the same stations to learn whether the size of pan caused any important difference in evaporation. Although there are small differences (table 18) associated with the sizes of the pans, they are neither consistent nor significant. Presumably the larger pans with the false bottoms gave the more reliable measures of evaporation and, although not significant, the difference tended to be in the direction of lower evaporation and greater condensation with the larger pans.

Pans from which depth of evaporation was derived were weighed only when there was no record of precipitation. Thus during periods of rain or snowfall, evaporation records were not obtained except at one station in 1938. In that year a peaked roof was constructed about 2 feet above one of

TABLE 19

COMPARATIVE EVAPORATION FROM SNOW, ICE, AND WATER

\begin{tabular}{|c|c|c|c|c|c|c|c|c|c|}
\hline \multirow{3}{*}{ Forest type } & \multicolumn{3}{|c|}{1938} & \multicolumn{3}{|c|}{1940} & \multicolumn{3}{|c|}{1941} \\
\hline & Snow & Ice & Water & Snow & Ice & Water & Snow & Ice & Water \\
\hline & \multicolumn{9}{|c|}{ Evaporation, depth of water in inches per month } \\
\hline Large opening near river........ & 0.03 & 0.39 & 0.39 & $\ldots$ & $\ldots$ & $\ldots$ & $\ldots$ & $\ldots$ & $\ldots$ \\
\hline Ponderosa pine, mature......... & $\ldots$ & $\ldots$ & $\ldots$ & 0.21 & 0.33 & 2.40 & 0.03 & 0.45 & 3.60 \\
\hline Mixed conifer, cutover............ & $\ldots$ & $\ldots$ & $\ldots$ & 0.45 & 0.33 & 2.16 & 0.18 & $\ldots$ & 2.85 \\
\hline White fir, mature............. & $\ldots$ & & $\ldots$ & 0.21 & 0.24 & 0.63 & 0.03 & $\ldots$ & $\ldots$ \\
\hline 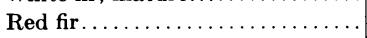 & $\ldots$ & & $\ldots$ & -0.03 & $\ldots$ & -0.27 & -0.06 & & $\ldots$ \\
\hline
\end{tabular}

the pans, and another pan was located close to the one under the shelter. Comparisons were made of evaporation in periods of precipitation, and the effect of the shelter on evaporation was studied. The results are shown in Table 18. The pan under the roof, as compared with the one outside, showed slightly higher evaporation during the days and slightly lower evaporation during the nights in periods without precipitation. When the pan under the shelter was weighed at periods with and without precipitation, the same comparison was evident. Again, the differences are small and not significant, and it is unlikely that any serious error resulted from the fact that the pans at other stations yielded records only for periods without precipitation. As in the other records of evaporation, the amounts are very small and almost negligible as a factor in the total loss of water from the snow.

In 1938,1940 , and 1941, late in the spring or at other times when it was difficult to find sufficient snow, some of the pans were operated with water which frequently froze and formed an ice layer. In this way, evaporation from snow, from ice, and from water was compared in several of the forest types (table 19). The magnitudes of evaporation from the snow in these comparisons are quite similar to those obtained for the whole snow seasons in these and other years. The evaporation from ice is, in most cases, decidedly higher than that from snow. This may be attributable, in part, to the melting of the ice during part of the time between weighings. If this happened so that only water was in the pan during a sunny day, the water tempera- 
ture might be strongly increased, with a resulting increase in evaporation. This is indicated clearly by the large depths of evaporation from the pans which contained only water. The evaporation from the water is many times as large as that from snow. It is interesting that the average evaporation from a floating pan in Lake Eleanor, 15 miles south at an elevation of 4,650 feet, averaged 2.43 inches per month from December to May, over an eightyear period (43). This is approximately the average evaporation from the pans containing water. The sequence of evaporation from water in the open logged, ponderosa pine, and mixed conifer areas is a descending one, and doubtless reflects the increase in shading of the pans in the progressively denser forest.

TABle 20

RATE OF SEASONAL EVAPORATION PER MONTH FROM SNOW, BY FOREST TYPES AND SEASONS

\begin{tabular}{|c|c|c|c|c|c|c|c|c|}
\hline \multirow{2}{*}{ Forest type } & \multicolumn{7}{|c|}{ Median evaporation per month, depth of water in inches } & \multirow{2}{*}{$\begin{array}{c}\text { Means } \\
\text { of all } \\
\text { seasons }\end{array}$} \\
\hline & 1934 & 1935 & 1936 & 1937 & 1938 & 1940 & 1941 & \\
\hline Large opening near river. & $-0.18^{*}$ & 0.00 & 0.06 & 0.03 & 0.03 & $\ldots$ & $\ldots$ & -0.01 \\
\hline Ponderosa pine, mature $\ldots \ldots \ldots \ldots$ & 0.03 & 0.09 & 0.06 & 0.27 & -0.06 & 0.15 & 0.03 & 0.08 \\
\hline 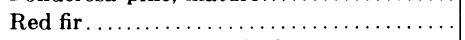 & 0.03 & 0.12 & 0.36 & 0.33 & -0.06 & -0.03 & -0.06 & 0.10 \\
\hline Ponderosa pine, $14 \mathrm{ft}$. high . . . . . . . . . & -0.06 & 0.12 & 0.39 & 0.30 & -0.06 & $\ldots$ & $\ldots$ & 0.14 \\
\hline Sugar-ponderosa pine...... & -0.27 & 0.06 & 0.24 & 0.51 & 0.18 & $\ldots$ & $\ldots$ & 0.14 \\
\hline White fir, immature...... & 0.24 & 0.15 & 0.24 & 0.15 & -0.06 & $\ldots$ & $\ldots$ & 0.14 \\
\hline Open screened .......... & 0.36 & 0.09 & 0.09 & 0.33 & -0.03 & $\ldots$ & $\ldots$ & 0.17 \\
\hline Open logged ......... & 0.03 & 0.12 & 0.12 & 0.51 & 0.12 & 0.18 & 0.12 & 0.17 \\
\hline White fir, mature..... & 0.24 & 0.06 & 0.45 & 0.27 & -0.03 & 0.21 & 0.03 & 0.18 \\
\hline Mixed conifer, cutover... & -0.33 & 0.03 & 0.54 & 0.93 & 0.03 & 0.45 & 0.18 & 0.26 \\
\hline Open meadow, $5,550 \mathrm{ft} . \ldots \ldots \ldots$ & 0.36 & 0.09 & 0.27 & $\ldots$ & 0.48 & $\cdots$ & $\cdots$ & 0.30 \\
\hline
\end{tabular}

* Minus signs indicate condensation in excess of evaporation.

In Table 19 and elsewhere the influences of types of different densities on evaporation from snow either are not evident or may be conflicting. In any case the magnitudes and differences are so small that they are not significant, and the inconsistencies are of little importance.

Evaporation data, by seasons, for the various cover areas are given in Table 20. The highest, 0.3 inch per month, was in the open meadow, and the lowest, a slightly negative value, in the large opening near the river. The latter probably reflects the high condensation associated with the high humidities and low temperatures in the valley bottom. The sequence of types of cover is not a logical one and is difficult to explain on the basis of cover conditions. The red fir at the higher elevation on a north exposure shows 0.1 of an inch of water evaporated per month, whereas the mature white fir, a similar stand in a corresponding location except for altitude, shows 0.18 inch.

There are also marked differences in evaporation in different seasons. Those of 1934 and 1938 showed generally low evaporation with negative values in several types indicating that gains by condensation exceeded losses by evaporation. Comparatively high evaporation characterized 1936 and 1937. As a whole, the conclusion from these figures is that evaporation from the snow is only a minor source of loss of water in any of the cover conditions in the locality under observation. 
Differences in daily evaporation between stations within any of the types were rarely significant. However, when the figures for monthly evaporation are classified into two groups, one for the stations under the crowns and the other for those in openings between the crowns, interesting comparisons appear as shown by types and seasons (table 21). Five out of seven of the cover types showed less monthly evaporation at the stations in the openings than at those under the crowns. The other two-immature white fir

TABLE 21

MEDIAN RATES OF SEASONAL EVAPORATION FROM SNOW UNDER CROWNS (U) AND IN OPENINGS (O), BY FOREST TYPES AND SEASONS

\begin{tabular}{|c|c|c|c|c|c|c|c|c|c|}
\hline Forest type & $\begin{array}{l}\text { Crown } \\
\text { cover }\end{array}$ & \multicolumn{7}{|c|}{ Season } & $\begin{array}{c}\text { Means } \\
\text { of all } \\
\text { seasons }\end{array}$ \\
\hline & & \multicolumn{7}{|c|}{ Evaporation depth of water in inches per month } & \\
\hline \multirow[t]{2}{*}{ Sugar-ponderosa pine .......... } & $\mathbf{U}$ & -0.30 & $\ldots$ & $\ldots$ & 0.72 & 0.30 & $\ldots$ & $\ldots$ & 0.24 \\
\hline & $\mathrm{O}$ & -0.24 & 0.06 & 0.24 & 0.06 & $-0.27 \ddagger$ & $\ldots$ & $\cdots$ & -0.03 \\
\hline \multirow[t]{2}{*}{ Ponderosa pine, mature ........ } & $\mathbf{U}$ & $\ldots$ & $\ldots$ & $\ldots$ & 0.18 & 0.03 & $\ldots$ & 0.27 & 0.16 \\
\hline & $\mathbf{O}$ & 0.03 & 0.09 & 0.06 & 0.24 & $-0.06 \ddagger$ & 0.21 & $0.03 \ddagger$ & 0.09 \\
\hline \multirow[t]{2}{*}{ Ponderosa pine, $14 \mathrm{ft}$. high...... } & $\mathbf{U}$ & -0.06 & 0.12 & 0.39 & 0.18 & -0.06 & $\ldots$ & & 0.11 \\
\hline & $\mathrm{O}$ & $\cdots$ & $\cdots$ & $\cdots$ & 0.06 & $\cdots$ & $\cdots$ & $\cdots$ & 0.06 \\
\hline \multirow[t]{2}{*}{ White fir, immature .......... } & $\mathbf{U}$ & $\ldots$ & 0.12 & -0.03 & $0.03^{*}$ & -0.06 & $\ldots$ & $\ldots$ & 0.03 \\
\hline & $\mathbf{O}$ & 0.09 & 0.30 & 0.24 & 0.15 & 0.00 & $\cdots$ & $\cdots$ & $0.16 \ddagger$ \\
\hline Red fir................ & $\mathbf{U}$ & 0.03 & $\ldots$ & $\ldots$ & 0.30 & -0.42 & -0.03 & -0.06 & -0.04 \\
\hline
\end{tabular}

* Based on a single record.

$\dagger$ Minus signs indicate condensation in excess of evaporation.

$\ddagger$ Difference is significant.

and red fir-indicated larger evaporation in the openings. In openings of sufficient size, the air temperatures and vapor pressures during the day are higher than those of the snow surface, and by amounts in excess of those under the crowns. Thus the negative vapor pressure differences are larger, resulting in greater condensation and, consequently, less net evaporation in the openings. It may be that the reversal of this relation in the two fir types is associated with the fact that the openings in these rather dense stands were small and therefore less effective in promoting condensation. However, the attempt to explain the results is perhaps superfluous when the difference between the means was significant only for the immature white fir, and when only four of the differences in medians for individual years, as shown by asterisks in Table 21, were significant.

\footnotetext{
${ }^{6}$ Differences were tested for significance by Miles' method (g4).
} 
If any general conclusion is justified from these data, it would be that the presence of openings between the crowns in a stand of trees tends to reduce the net evaporation. Even more generally, it might be concluded that, whatever the condition of cover, the loss of water by evaporation from the snow, from 0 to 0.3 inch per month, is a minor factor in the disposition of the water from the snow in this locality and probably also on most of the west slope of the Sierra Nevada and Cascade mountains.

Duration and Disappearance of Snow Cover.-The end point of evaporation and melting, in time, is the date of disappearance of the snow. The depth and water equivalent also become zero on the same date. Duration of the snow involves also an initial date, which varied from December 12 to

TABLE 22

DATE OF FIRST SPRING RECORD OF BARE GROUND AT ANY STATION IN EACH FOREST TYPE, BY SEASONS

\begin{tabular}{|c|c|c|c|c|c|c|c|c|}
\hline \multirow{2}{*}{ Forest type } & \multirow{2}{*}{$\begin{array}{l}\text { Medians } \\
\text { of all } \\
\text { seasons }\end{array}$} & \multicolumn{7}{|c|}{ Season } \\
\hline & & 1934 & 1935 & 1936 & 1937 & 1938 & 1940 & 1941 \\
\hline Large clearing $\ldots \ldots \ldots \ldots \ldots \ldots \ldots \ldots$ & $3 / 28$ & $3 / 1$ & $3 / 28$ & $4 / 9$ & $4 / 11$ & $4 / 17$ & $3 / 4$ & $3 / 10$ \\
\hline Ponderosa pine, mature ............ & $3 / 28$ & $2 / 27$ & $3 / 28$ & $4 / 8$ & $4 / 3$ & $4 / 13$ & $3 / 1$ & $3 / 8$ \\
\hline Mixed conifer, cutover..... & $3 / 29$ & $2 / 25$ & $3 / 29$ & $4 / 9$ & $4 / 7$ & $4 / 18$ & $3 / 2$ & $2 / 19$ \\
\hline Ponderosa pine, $14 \mathrm{ft}$. high.... & $3 / 31$ & $2 / 28$ & $3 / 28$ & $4 / 8$ & $3 / 31$ & $4 / 14$ & $\ldots$ & $\ldots$ \\
\hline White fir poles............... & $4 / 7$ & $2 / 18$ & $3 / 31$ & $4 / 9$ & $4 / 7$ & $4 / 20$ & $\ldots$ & $\ldots$ \\
\hline Sugar-ponderosa pine.......... & $4 / 9$ & $2 / 29$ & $4 / 19$ & $4 / 9$ & $3 / 14$ & $4 / 15$ & $\ldots$ & $\ldots$ \\
\hline White fir, mature............ & $4 / 10$ & $2 / 28$ & $4 / 17$ & $4 / 10$ & $4 / 17$ & $4 / 28$ & $3 / 3$ & $1 / 30$ \\
\hline Open meadow, 5,550 feet. . . . . . . . . & $4 / 15$ & $3 / 6$ & $4 / 21$ & $4 / 12$ & $4 / 15$ & $5 / 11$ & $\ldots$ & $\ldots$ \\
\hline Open screened . .................... & $4 / 16$ & $3 / 8$ & $4 / 16$ & $4 / 11$ & $4 / 18$ & $5 / 6$ & $\ldots$ & $\ldots$ \\
\hline 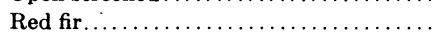 & $5 / 3$ & $3 / 14$ & $5 / 6+$ & $4 / 20$ & $5 / 3$ & $5 / 16$ & $4 / 9$ & $5 / 5$ \\
\hline Open meadow, 6,500 feet. . . . . . . . . . & $5 / 25$ & $\ldots$ & $\ldots$ & $\ldots$ & $\ldots$ & $5 / 25$ & $\ldots$ & $\ldots$ \\
\hline
\end{tabular}

January 4 in different years. The same storm provides the first lasting snow each year so that the initial date of snow cover is the same in all types and usually at all stations. Snow sometimes falls earlier in November or December, but does not persist. In years of light snowfall, patches of bare ground may be exposed at any time during the winter, but this did not happen continuously during any of the seven seasons of record.

The disappearance of the snow begins with the exposure of bare ground. Dates of the first spring records of bare ground at any station, for each type and season, are given in Table 22. There are large differences among seasons because of variations in amount and distribution of the snowfall. The latest dates of exposure of bare ground were in the 1938 season of heaviest snow, and the earliest, in 1934 when there was little snowfall. The difference in dates between seasons for the same cover may be more than 60 days, as in the white and red fir types between 1934 and 1938.

Differences are also marked among different conditions of cover although some of them are not what would be expected from consideration of exposure to agencies of melting. Doubtless this is another instance of the opposing influences of different kinds of cover on interception, accumulation, and melting of the snow. Bare ground appeared first in the large clearing and mature ponderosa pine types. As compared with the clearing, bare ground 
showed a few days later in the young dense ponderosa pine and in the open stand of cutover mixed conifer, 10 to 19 days later in the white fir areas, the open screened area, and the lower meadow, and 36 days later in the red fir.

From the first exposure the area of bare ground increased, with exceptions when fresh snow fell, until the last of the snow disappeared. The dates of final disappearance are given in Table 23. Again there is wide variation among seasons. The snow lasted longest in the 1938 season of maximum snowfall, and disappeared earliest in the 1934 season of minimum snowfall, with differences of more than two months between these two seasons in some types.

The last snow disappeared earliest in the ponderosa pine and in the open exposed areas-about April 20 as a five-year average. The date was only a

TABLE 23

DATE AT LAST DISAPPEARANCE OF SNOW AT ANY STATION WITHIN EACH FOREST TYPE, BY SEASONS

\begin{tabular}{|c|c|c|c|c|c|c|c|c|}
\hline \multirow{2}{*}{ Forest type } & \multirow{2}{*}{$\underset{1934-38}{\text { Medians }}$} & \multicolumn{7}{|c|}{ Season } \\
\hline & & 1934 & 1935 & 1936 & 1937 & 1938 & 1940 & 1941 \\
\hline Ponderosa pine, mature..... & $4 / 17$ & $3 / 4$ & $4 / 17$ & $4 / 10$ & $4 / 17$ & $4 / 28$ & $3 / 7$ & $3 / 16$ \\
\hline Ponderosa pine, $14 \mathrm{ft}$. high... & $4 / 20$ & $3 / 4$ & $4 / 20$ & $4 / 10$ & $4 / 20$ & $5 / 9$ & $\ldots$ & $\ldots$ \\
\hline Open meadow, 5,550 feet. . . & $4 / 21$ & $3 / 10$ & $4 / 23$ & $4 / 16$ & $4 / 21$ & $5 / 7$ & $\ldots$ & $\ldots$ \\
\hline Open logged $\ldots \ldots \ldots \ldots$ & $4 / 23$ & $3 / 7$ & $4 / 23$ & $4 / 14$ & $4 / 26$ & $5 / 9$ & $3 / 6$ & $3 / 24$ \\
\hline White fir poles...... & $4 / 24$ & $3 / 4$ & $4 / 24$ & $4 / 12$ & $4 / 24$ & $5 / 11$ & $\ldots$ & $\ldots$ \\
\hline White fir, mature........ & $5 / 2$ & $3 / 6$ & $5 / 2$ & $4 / 15$ & $5 / 6$ & $5 / 17$ & $3 / 15$ & $3 / 26$ \\
\hline Sugar-ponderosa pine..... & $5 / 4$ & $3 / 15$ & $5 / 8$ & $4 / 20$ & $5 / 4$ & $5 / 22$ & $\ldots$ & $\ldots$ \\
\hline Open screened ............ & $5 / 6$ & $3 / 26$ & $5 / 6$ & $4 / 23$ & $5 / 6$ & $5 / 15$ & $\ldots$ & $\ldots$ \\
\hline Mixed conifer, cutover $\ldots \ldots \ldots \ldots \ldots \ldots$ & $5 / 7$ & $3 / 15$ & $5 / 7$ & $4 / 19$ & $5 / 7$ & $5 / 19$ & $3 / 25$ & $5 / 2$ \\
\hline Open meadow, 6,500 feet $\ldots \ldots \ldots \ldots \ldots$ & $\ldots$ & $\ldots$ & $\ldots$ & $\ldots$ & $\ldots$ & $6 / 9$ & $\ldots$ & $\ldots$ \\
\hline 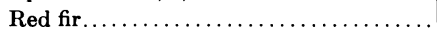 & $6 / 1$ & $4 / 12$ & $\ldots$ & $5 / 19$ & $6 / 1$ & $6 / 14$ & $5 / 10$ & $6 / 1$ \\
\hline
\end{tabular}

few days later in the white fir poles. In the mature fir, mixed conifer, and open screened areas, it was 9 to 14 days later, and in the red fir, 41 days later than in the meadow at 5,550 feet.

The date of disappearance of the snow varied also at different locations within the same stand in relation to crowns and openings. The crown coverage of circular areas 20 feet in radius around the stations was the only measure of density that showed well-defined relations to the date of disappearance. The resulting linear trends shown in figures 53, 54, and 55 had significant regression coefficients for each year in the cutover mixed conifer stand and for some years in the mature ponderosa pine and mature white fir. They are expressed in the equations tabulated below, where $Y$ is date of disappearance expressed as the number of days after the end of February, and $c$ is coverage in per cent. The differences between regression coefficients were significant only between the 0.68 of the cutover mixed conifer, in 1941, and the others. The reason for the steep slope of the trend in this type in 1941 is not evident. For the other seasons, the data were combined to give a single coefficient of 0.20 , but it was not significant when tested and is therefore probably less reliable than the appropriate one for an individual year and type. The differences between years, and particularly the $Y$-intercepts, reflect in part the differences in amounts of snow which, in turn, have been 

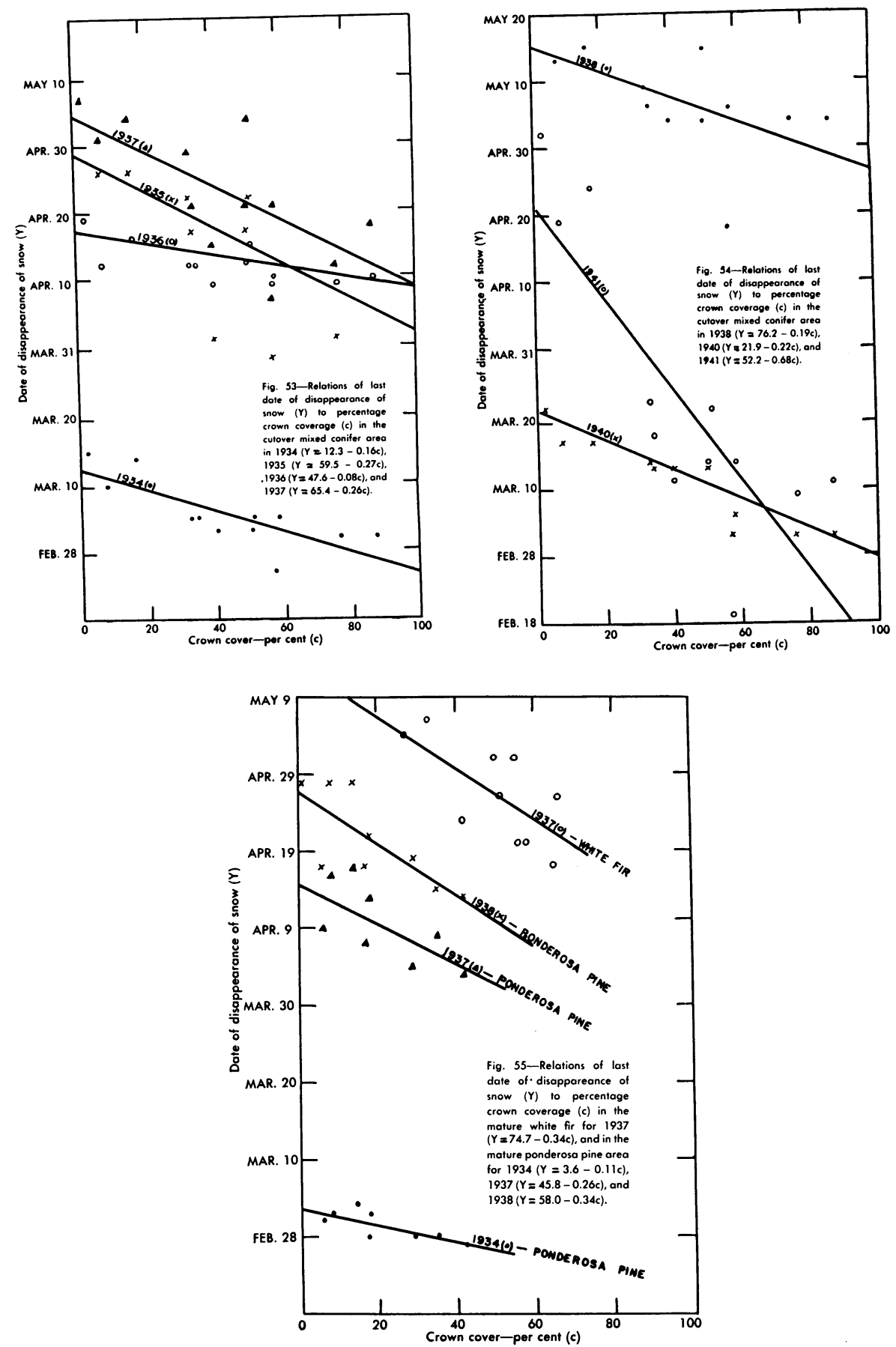
shown to be related to the dates of disappearance. The regression coefficients indicate the rates of change in dates of disappearance associated with unit change in percentage of cover. For example, the coefficient of 0.22 for the cutover mixed conifer in 1940 may be interpreted by the statement that the date of disappearance of the snow would be 2.2 days later if the crown coverage were reduced by 10 per cent. The corresponding figures for other types and years indicate dates of disappearance of from 0.8 to 6.8 days later, associated with 10 per cent reductions in coverage.

The equations may be used to estimate the date of disappearance for any given coverage or the change in dates if the cover is reduced by cutting. Thus, in a season of light snowfall like 1934, in a mature stand of ponderosa

\begin{tabular}{|c|c|c|c|}
\hline Type & Season & $\begin{array}{l}\text { Regression } \\
\text { equations }\end{array}$ & $\begin{array}{l}\text { Standard } \\
\text { errors of } \\
\text { regression } \\
\text { coefficients }\end{array}$ \\
\hline Mature ponderosa pine....... & 1934 & $Y=3.6-0.11 c$ & 0.026 \\
\hline Mixed conifer, cutover $\ldots \ldots \ldots \ldots \ldots \ldots \ldots$ & 1934 & $Y=12.3-0.16 c$ & .038 \\
\hline Mixed conifer, cutover........ & 1941 & $Y=52.2-0.68 c$ & .148 \\
\hline Mixed conifer, cutover........ & 1936 & $Y=47.6-0.08 c$ & .028 \\
\hline Mixed conifer, cutover $\ldots \ldots \ldots \ldots \ldots \ldots \ldots$ & 1935 & $Y=59.5-0.27 c$ & .110 \\
\hline Mature ponderosa pine........ & 1937 & $Y=45.8-0.26 c$ & .082 \\
\hline Mixed conifer, cutover..... & 1937 & $Y=65.4-0.26 c$ & .083 \\
\hline
\end{tabular}

pine with 30 per cent crown coverage, the snow would disappear, on the average, on February 28. In a year of heavy snow like 1938, in cutover mixed conifer of 50 per cent coverage, the snow would disappear 67 days after February 28-or on May 6. Using the equations for 1937, another year of heavy snow, in the mature white fir with 70 per cent coverage, the snow would disappear on April 20. If the stand were cut, leaving 40 per cent coverage, the date of disappearance would be April 30. If it were assumed that the mixed conifer cutover of 40 per cent coverage represented a condition similar to that of the white fir cut to that density, the date of disappearance would be April 24. It might be expected that greater exposure of the snow in openings would accelerate melting and make the dates of disappearance earlier, but apparently the openings in these stands were not large enough to reflect that influence in opposition to the greater accumulations in the openings. In every case, a reduction in crown density results in a later date of disappearance.

The duration of the snow cover shown in Table 24 varies in different years and among different types of cover. The maximum range between years is 78 days in the large clearing. The shortest average duration is 117 days in the old ponderosa pine, and the longest, 160 days in the red fir area. In general, the open areas, those of southern aspect with ponderosa pine and the dense white fir, have the shorter durations of snow cover.

When the median date of first appearance of bare ground is subtracted from that of final disappearance of the snow in each type, a series of figures 
is obtained giving the average numbers of days for the snow to disappear after bare ground is first exposed. These figures vary from 6 days, in the meadow at 5,550 feet, to 30 days in the mixed conifer cutover. For most of the types they are between 14 and 20 days.

Just before the first bare ground appears, the snow covers 100 per cent of the area, and the percentages decrease to 0 in the foregoing numbers of days. The percentages of area covered by snow on intervening dates were computed as the ratios of the number of stations with snow to the total number of stations in each type. When these percentages were plotted over a time scale of dates, most of the seasons in most of the types showed well-defined linear rates of decrease. Deviations, in the form of less steep trends, occurred

TABLE 24

DURATION OF SNOW COVER IN DIFFERENT FOREST TYPES AND SEASONS

\begin{tabular}{|c|c|c|c|c|c|c|c|c|}
\hline \multirow{3}{*}{ Forest type } & \multirow{3}{*}{$\begin{array}{l}\text { Medians } \\
\text { of all } \\
\text { seasons }\end{array}$} & \multicolumn{7}{|c|}{ Season } \\
\hline & & 1934 & 1935 & 1936 & 1937 & 1938 & 1940 & 1941 \\
\hline & & \multicolumn{7}{|c|}{ Number of days } \\
\hline Ponderosa pine, mature.... & 115 & 23 & 123 & 119 & 115 & 128 & 62 & 94 \\
\hline Ponderosa pine, $14 \mathrm{ft}$. high. & 119 & 23 & 126 & 119 & 118 & 139 & $\ldots$ & $\ldots$ \\
\hline Large clearing. . . . . . . . . & 123 & 26 & 129 & 123 & 124 & 139 & 61 & 102 \\
\hline White fir poles........... & 122 & 23 & 130 & 121 & 122 & 141 & $\ldots$ & $\ldots$ \\
\hline White fir, mature....... & 124 & 25 & 138 & 124 & 134 & 147 & 70 & 104 \\
\hline Open meadow, 5,550 feet. & 125 & 68 & 129 & 125 & 119 & 137 & $\ldots$ & $\ldots$ \\
\hline Sugar-ponderosa pine.... & 132 & 73 & 144 & 129 & 132 & 152 & $\ldots$ & $\ldots$ \\
\hline Open screened .......... & 134 & 36 & 142 & 132 & 134 & 145 & $\ldots$ & $\ldots$ \\
\hline Mixed conifer, cutover... & 135 & 34 & 143 & 128 & 135 & 149 & 80 & 141 \\
\hline Red fir................ & 159 & 101 & $\ldots$ & 158 & 160 & 175 & 126 & 171 \\
\hline
\end{tabular}

in some instances during the first few days after bare ground appeared. These were disregarded, and the slopes of the well-defined portions were read to give rates of decrease in percentage of area covered by snow per day (table 25). These are the rates during the last part of the spring season when the snow is melting rapidly. Wide variations between years are evident, and they are wider in the types of rapid rates of decrease than in those of slower rates. The types are arranged in descending order of the five-year averages. The highest rate (17.2 per cent) for the lower meadow was doubtless caused in part by the accumulation of water on the ground surface as well as by exposure to sun and wind. The lowest rate ( 4.4 per cent) was in the red fir where lower temperatures were noticeable. The ponderosa pine types. on southern exposures and the white fir types of high density and interception had high rates of decrease, while the less dense, mixed conifer types had low rates of decrease. These rates are somewhat higher than those obtained by dividing 100 per cent by the number of days between first exposure of bare ground and final disappearance, because the latter represent the whole period of emergence of bare ground while the former are for the later part of the period when melting proceeds most rapidly. At 9,500 feet, in Colorado, from May 19 to July 12, the decrease in percentage of area covered 
by snow averaged 1.6 per cent per day. The trend clearly corresponded with that of the remaining percentage of total stream flow plotted over time (30). At the Upper Columbia Snow Laboratory the rates of decrease were 1.4 and 2.4 per cent per day in 1946 and 1948 , respectively $(33,34)$. These percentages should be useful in determining the rate of melting for an area as a whole when the rate of decrease in water equivalent of the snow has to be modified by a factor for the part of the area covered by snow.

Melting of Snow.-By definition, melting is the change from the solid to the liquid state. However, in this project the data used to indicate rates of melting are the changes in the water equivalents of the snow during periods of 1 to 3 days without precipitation. Thus evaporation and conden-

TABLE 25

MEAN DAILY DECREASE IN PERCENTAGE OF AREA COVERED BY SNOW IN SPRING, BY FOREST TYPES AND SEASONS

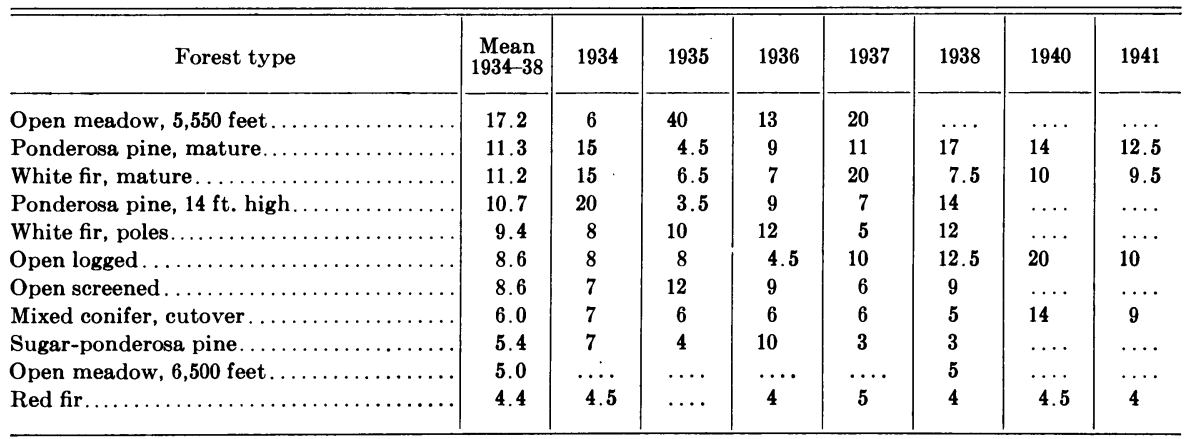

sation are included. Corrections for net evaporation could be applied, but they would be so small that conclusions would not be changed and the changes in amounts of water that drained from the snow would be insignificant. A reduction in water equivalent of the snow, if net evaporation is negligible, necessarily indicates drainage of water from the snow, whether this water is liquid from current melting or liquid from earlier melting stored in the slushy layer above the snow-soil interface, or a mixture of the two.

The effect of rain on the melting of snow is quite small because the temperature of the rain during the snow season is not much above freezing. In fact, precipitation that begins as rain usually becomes snow toward the end of the storm. A rain of 1 inch, if its temperature were $40^{\circ} \mathrm{F}$, would melt only 0.06 inch water equivalent of snow. When rain falls on snow which has not reached the density or degree of saturation at which drainage of water begins, it is retained in the snow layer, thus increasing its density and water equivalent without causing appreciable melting or drainage of water. If the snow is already at a density such that water is passing into the soil, rain adds to the amount of drainage only slightly more than the amount of the rain. In this case, rain adds to the depth of the water draining from the snow pack, but only a small part of the additional water comes from melting of the snow. On the other hand, the snow may retain part of the water, as in the following example from the Central Sierra Snow Labora- 
tory. The addition of 2 inches of water to a 2-foot column of coarse snow of 40 per cent density resulted, after 3 hours drainage by gravity, in the retention of about 5 per cent of liquid water in the snow (35).

Part of the heat of solar radiation is absorbed by the snow, and causes melting. To melt 1 inch water equivalent of dry snow requires 203.2 calories per square centimeter. Average daily radiation received on a horizontal surface at latitude 39 degrees varies from over 700 calories in June to 100 calories in January. Clean, dry snow reflects 80 or 90 per cent of the radiation, and dirty, moist snow, less than 50 per cent, so that the radiation absorbed is from 10 to 50 per cent of the incident. In January, therefore, only 10 calories per day may be effective in melting snow to 0.05 inch water equivalent. In June, however, 300 calories would melt 1.5 inches water equivalent. These figures would be decreased on a northern and increased on a southern exposure. Incoming radiation is also intercepted by the crowns of the trees to the south. Under dense crowns, less than 5 per cent of the insolation may penetrate (21). An uncut stand of red and white fir in Plumas County intercepted 85 per cent of the insolation. ${ }^{7}$ On December 21, a tree's shadow at noon, on level ground, will extend 1.8 times its height. On March 21, the shadow will be 0.78 times, on April 21, 0.49 times, and on June 21, 0.27 times the height. In openings in the forest less than one half the height of the trees to the south, direct insolation will have little effect except in May and June, or on southern exposures. Most of the openings in the stands where measurements were made in this study were less than one half the height of the trees, and only in 1938 (or in the red fir type in other years), did the snow remain after the first week in May.

In a multiple regression analysis of snow melt at the Fraser Experimental Forest in Colorado (9,500 feet), the partial regression coefficients for solar radiation (one of the eight independent variables used) were negative $(26)$. The inverse relation is not easily explained, but at least it suggests that direct insolation may not be so large a factor in melting snow as has usually been supposed.

Snow may also be melted by transmission of heat from the soil below or near the snow when the soil temperatures are above $32^{\circ} \mathrm{F}$. Soil temperatures at a depth of $11 / 2$ inches were recorded for short periods before and after the disappearance of the snow in 1934, 1940, and 1941. The soil beneath the snow was not frozen except when a shallow layer froze in the open before the snow came, and thawed shortly thereafter. For the few days before the snow disappeared, the soil temperatures varied from $30^{\circ}$ to $38^{\circ} \mathrm{F}$ and most frequently between $33^{\circ}$ and $35^{\circ} \mathrm{F}$. Soil temperatures above freezing, beneath a shallow snow layer, are to be expected in view of the evidence by Gerdel and others (14) that large amounts of solar radiation penetrate the snow to depths of 5 inches or more. As a result, the soil temperatures usually increased in the last few days of melting as the snow layer became shallower. Except for these last days before disappearance, the effect of heat transmission from the soil on the melting of the snow seemed to be of minor importance, as concluded by Wilson (40) and others (35) who give a maximum of 0.01 inch per day for snow melt water. However, at the Arnot Forest in

\footnotetext{
` From a manuseript by E. A. Colman, with his kind consent.
} 
New York, between March 9 and 19, above unfrozen ground in the forest, the snow decreased in depth by 7 inches; above unfrozen ground, in the open, by 16 inches, and above frozen ground, in the open, by 13 inches-a difference which is not minor (23).

After the snow disappeared, the soil temperatures increased to $40^{\circ} \mathrm{F}$ within a few days. In the meadow, the temperature increased from $33^{\circ}$ to $57^{\circ} \mathrm{F}$ in five days. In the sugar-ponderosa pine type, it rose from $35^{\circ}$ to $47^{\circ} \mathrm{F}$ in seven days. In the ponderosa pine, it increased from $40^{\circ}$ to $65^{\circ} \mathrm{F}$ in six days. These rates of increase, sometimes over 4 degrees per day, are extreme examples. The usual changes were more gradual, and increases were interspersed with decreases diurnally and as the weather changed. In general, soil temperatures of $40^{\circ}$ to $50^{\circ} \mathrm{F}$ prevailed shortly after the snow disappeared. Thus, as the area of bare ground increases, its heat accelerates the melting of the remaining snow.

Some snow is also melted by the heat released in the process of condensation. The records obtained in this study give the combined effects of condensation and evaporation in periods of one half to three days, so that condensation cannot be segregated. The maximum monthly depth of water condensed in excess of evaporation in any forest type in Table 20 is 0.33 inch. The depth of water melted is 7.5 times the depth condensed (the ratio of latent heat of vaporization to latent heat of fusion ). Thus the depth melted per month by condensation might sometimes be as much as 2.5 inches water equivalent, or 0.08 inch per 24 hours. This depth of melting is small compared with total daily rates of 0.5 to 1.0 inch. Moreover, the 0.08 inch is a maximum figure, and the actual depths melted by condensation would usually be much smaller and probably negligible.

The melting of snow has frequently been expressed as a function of the air temperature in degree-days above $32^{\circ} \mathrm{F}$. In this way, melting may be estimated from records of daily temperatures. Actually, the air temperatures in this relation serve as approximate indexes of the combined effects of incoming radiation and turbulent mass exchange. Daily records of air temperatures, in a standard shelter within 140 feet of two of the snow stations in the old ponderosa pine type, for the four seasons of heavy snow, were furnished through the courtesy of the California Forest and Range Experiment Station. Thus, the degree-days above $32^{\circ} \mathrm{F}$ were compiled for each of the 36 periods of 1 to 7 days without precipitation, between December 23 and April 28, for which the decreases in water equivalent of the snow were available.

When these decreases in water equivalent were plotted over degree-days for each short period, the wide dispersion of the points precluded the possibility of a usable relation. When the periods were combined and the cumulated data plotted by months, the dispersion was reduced, but not enough for the satisfactory definition of a trend. Finally, each set was cumulated progressively for each year, and points were plotted for each date (fig. 56). The points for 1935, 1937, and 1938 formed a single, narrow, linear band with a regression equation, $d=0.096 t-0.97$, where $d$ is depth of decrease in water equivalent of the snow and $t$ is degree-days above $32^{\circ} \mathrm{F}$. The rate of melting, per degree-day, of about 0.10 corresponds with values reported 


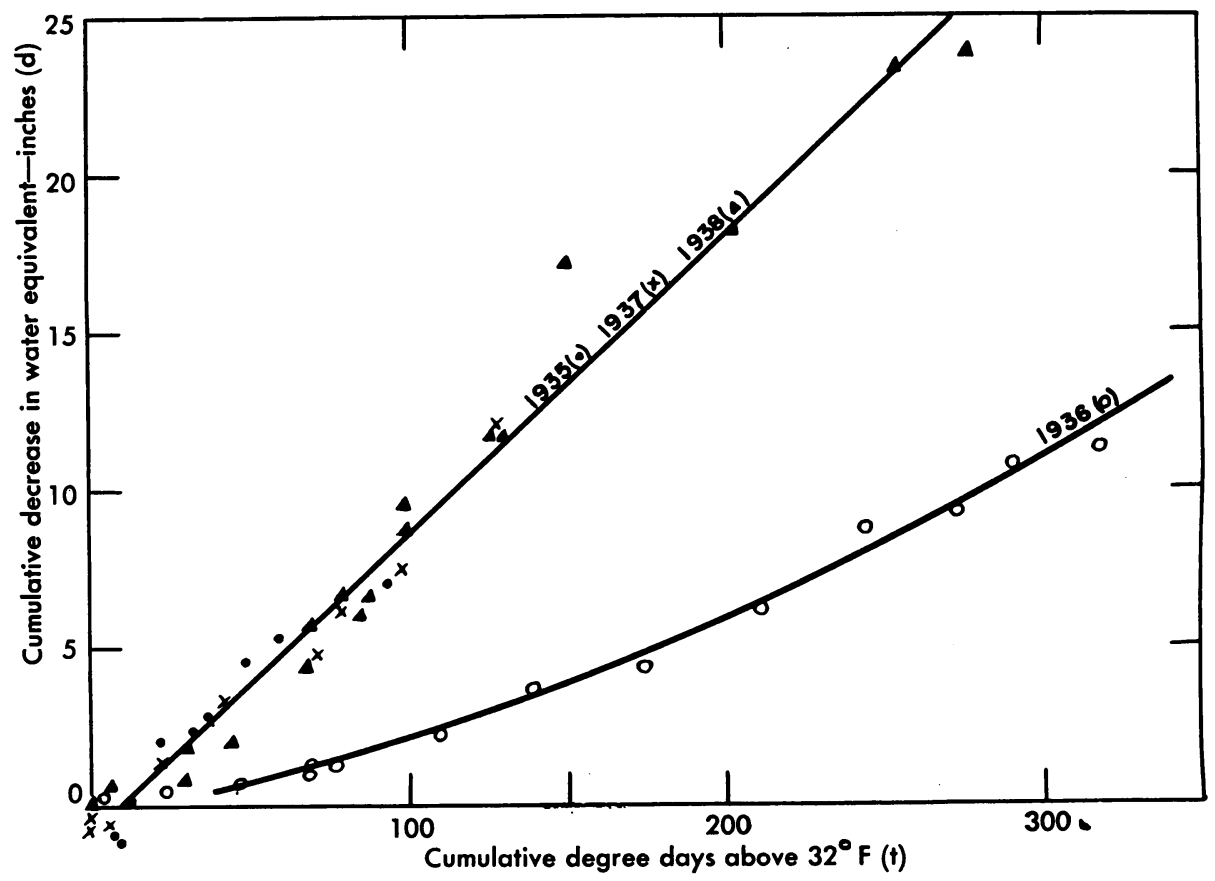

Fig. 56.-Relations of cumulative decrease in water equivalent of snow to cumulative degreedays above $32^{\circ} \mathrm{F}$ for periods without precipitation, in the old ponderosa pine area, $d=0.10 t-$ 0.97 and $d=0.0022 t^{1.5}$.

from California, Montana, Utah, and Pennsylvania (32, 35, 8, 19). In Pennsylvania, however, the rate of 0.09 in cut and burned areas was reduced to 0.06 for moderately dense stands of hardwood and hemlock 40 to 50 years old. For 1936, in the ponderosa pine, the slope of the trend was about 0.04 when a slightly accelerating curvature was disregarded. This also is close to the lower values found by others. At 9,500 feet, in Colorado in May and June, 1948, the slope was a little less than $0.02(26)$. If the first two points, for less than 25 degree-days, are ignored, the rest of the points conform closely to a linear trend on log-log paper with an equation, $\log d=1.50 \mathrm{log}$ $t-2.66$, or $d=0.0022 t^{1.5}$. This trend would indicate that the rate of melting increases as the $3 / 2$ power of the degree-days. Why this trend for 1936 is different from those for 1935, 1937, and 1938 is not evident, but it affords a good example of the possibility that this relation may vary from year to year presumably with climatic differences, and that estimates made by the use of such equations for other years may sometimes be unreliable.

The data for 1941, from an open area near Crater Lake (6,450 feet) in southern Oregon (42), illustrate a similar relation. The correlation between water losses and degree-days for the short periods, as units, is low, and the ratios of melt loss per degree-day vary widely-from 0.03 to 0.66 -with an average of 0.15 . When the values are cumulated and plotted on log-log paper, 
however, the trend is strictly linear with little dispersion, and can be represented as $\log d=1.88 \log t-3.01$, or $d=0.001 t^{1.88}$. The constants in this equation are not widely different from those for the California data of 1936, but the differences are not negligible. Thus, while there are well-defined relations between cumulative melting and cumulative degree-days, further study will be required to know in advance what form of equation and what constants should be used to estimate the melting from temperature data.

The foregoing relations were derived from air temperatures 3 or 4 feet above the surface of the snow, but the air temperatures will certainly decrease. (and at an accelerating rate) with decreasing distance from the surface. Differences of $6^{\circ}$ and $7^{\circ} \mathrm{F}$ between 50- and 4-foot levels were recorded at the Central Sierra Snow Laboratory (32). Nearby, at 9:30 A.M. on May 6, the temperature at 1 inch above the snow was $38^{\circ}$, and "on snow," $32.5^{\circ} \mathrm{F}$. At 2:15 P.M. on April 16, at Truckee, at 9 feet, 18 inches, and "on snow," the temperatures were $68.5^{\circ}, 67^{\circ}$, and $41^{\circ} \mathrm{F}(7)$. It seems likely that the correlation between degree-days and melting would be higher if air temperatures were measured close to the surface of the snow. Furthermore, it may be that this effect of the snow on the temperature of the air just above it explains why differences in melting and evaporation between shaded and open areas are so much smaller than would be expected, considering the large differences in incident solar radiation.

The date of disappearance of the snow considered in preceding sections can be used as a factor in deriving the rate of melting. If both date of disappearance and the water equivalent at some earlier date are known, the actual average rate of decrease can be determined, because the dates of disappearance, when plotted over water equivalents on March 1 for individual stations in each forest type, give well-defined linear trends as shown in figures 57-70. The regression coefficients were highly significant, and dates of disappearance could be estimated from the water equivalents on March 1. Maximum water equivalents could also be used in the same way, but it seemed more useful to develop the relations on the basis of a fixed date near the usual start of the melting season. March 1 is also a date on which snow surveys are made, and the regressions might be used to estimate dates of disappearance from the March 1 water equivalents of the surveys.

Regression equations were derived for each cover type. They were segregated for two groups of years when it became evident that the slopes of the trends for the four years 1935-1938, which had more than 7 inches average water equivalent of snow, were distinctly less steep than those for the three years, 1934, 1940, and 1941, which averaged less than 3.5 inches on March 1. The differences in the regression coefficients between the two groups were highly significant except in the large clearing. On the contrary, the differences among types were not significant in the 1935-1938 years, and the data for all types were combined to give a single coefficient of 1.68. The $Y$-intercepts were then recomputed for each type. The resulting equations are given in Table 26, arranged in ascending order of the $Y$-intercepts for 1935-1938. Where the regression coefficient is the same, this order is also the sequence of increasing numbers of days to disappearance of the snow. Assuming 10 inches water equivalent of snow on March 1, the snow would 
[ Vol. 22, No. 1
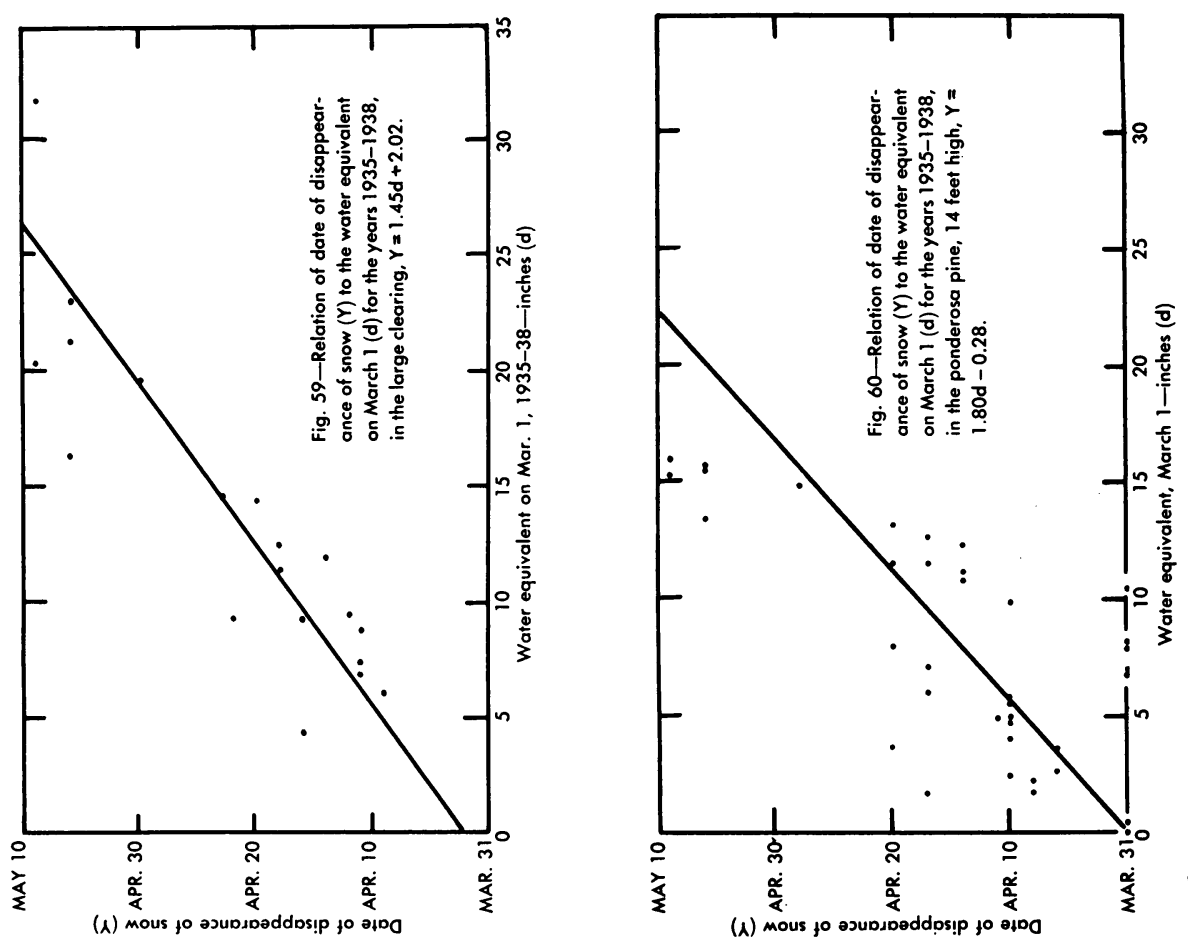

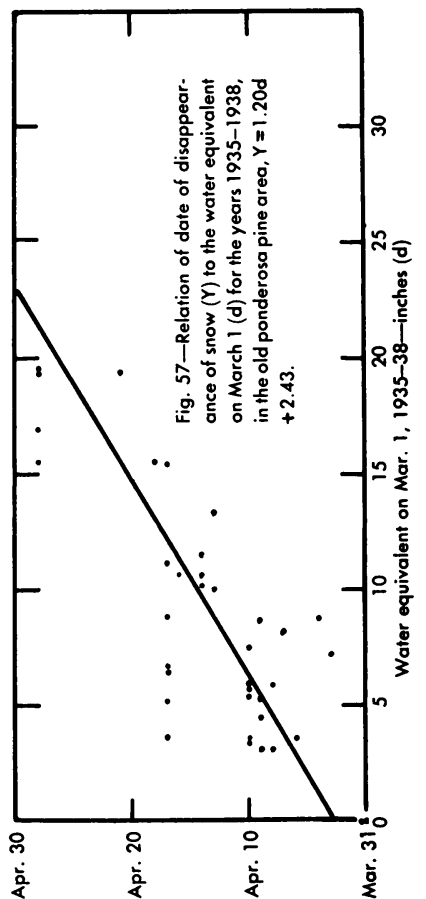

(A) Mous to exuojoeddlos!p to et०o

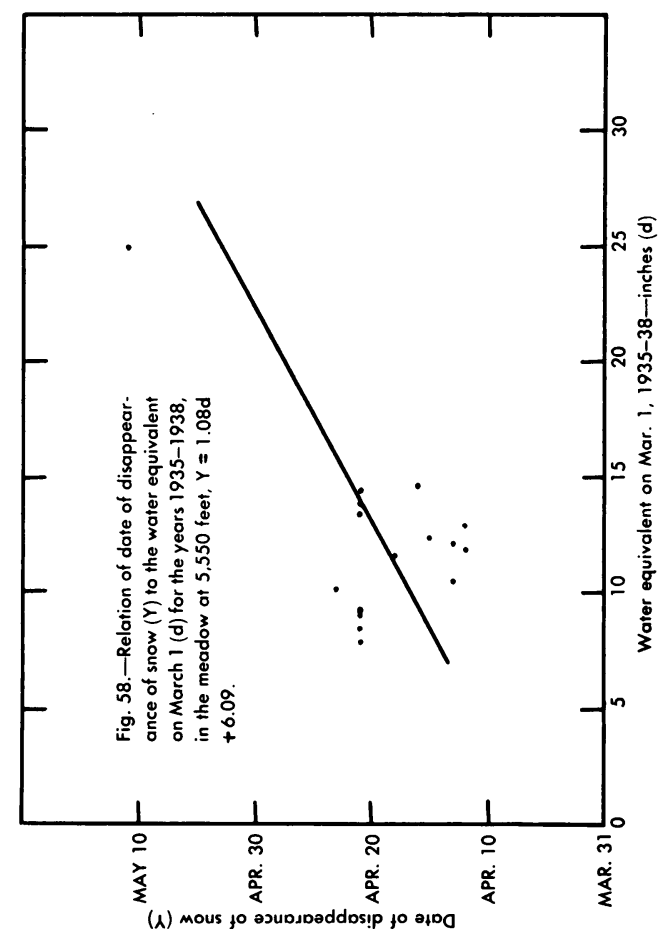


March, 1953]
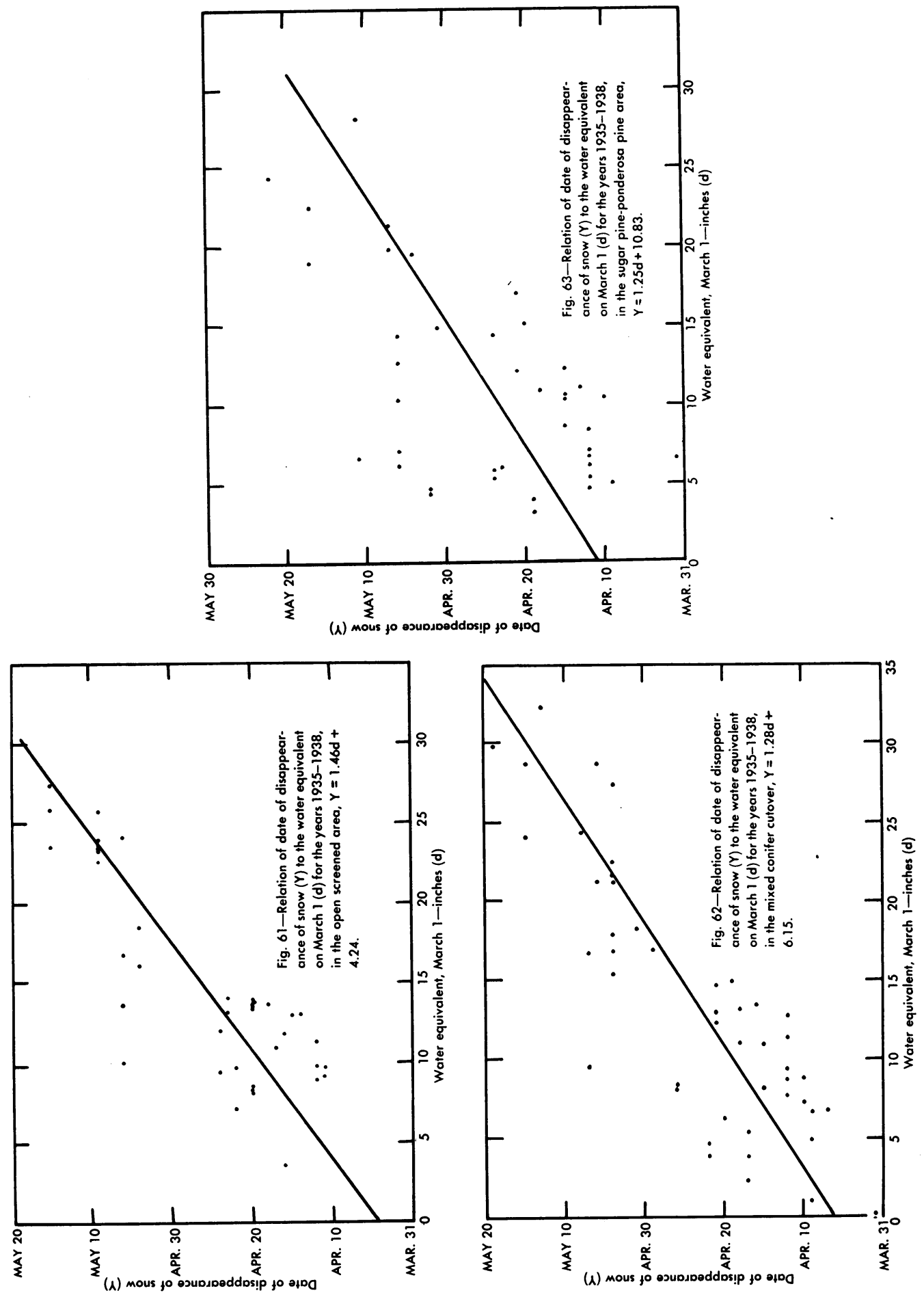

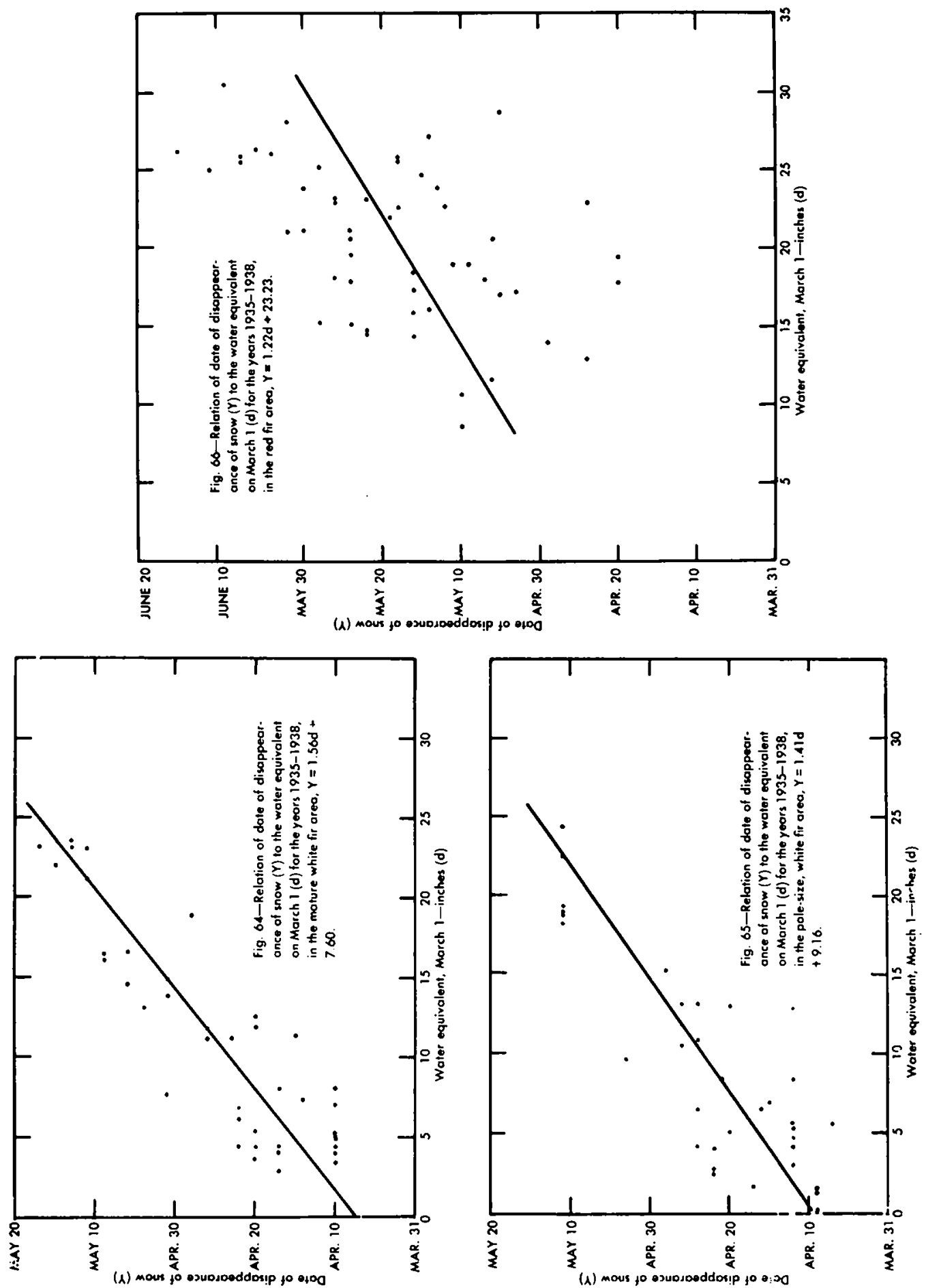

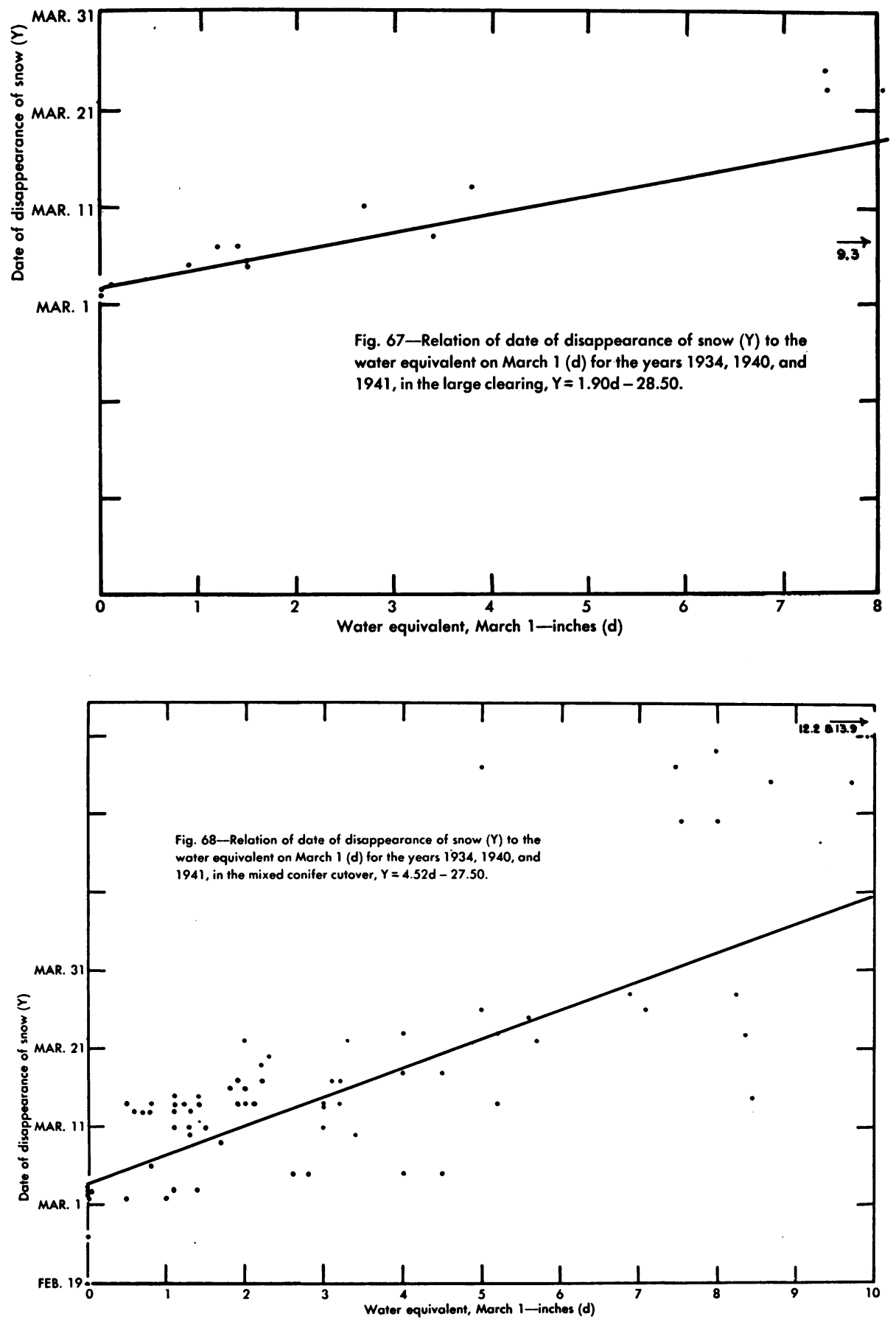


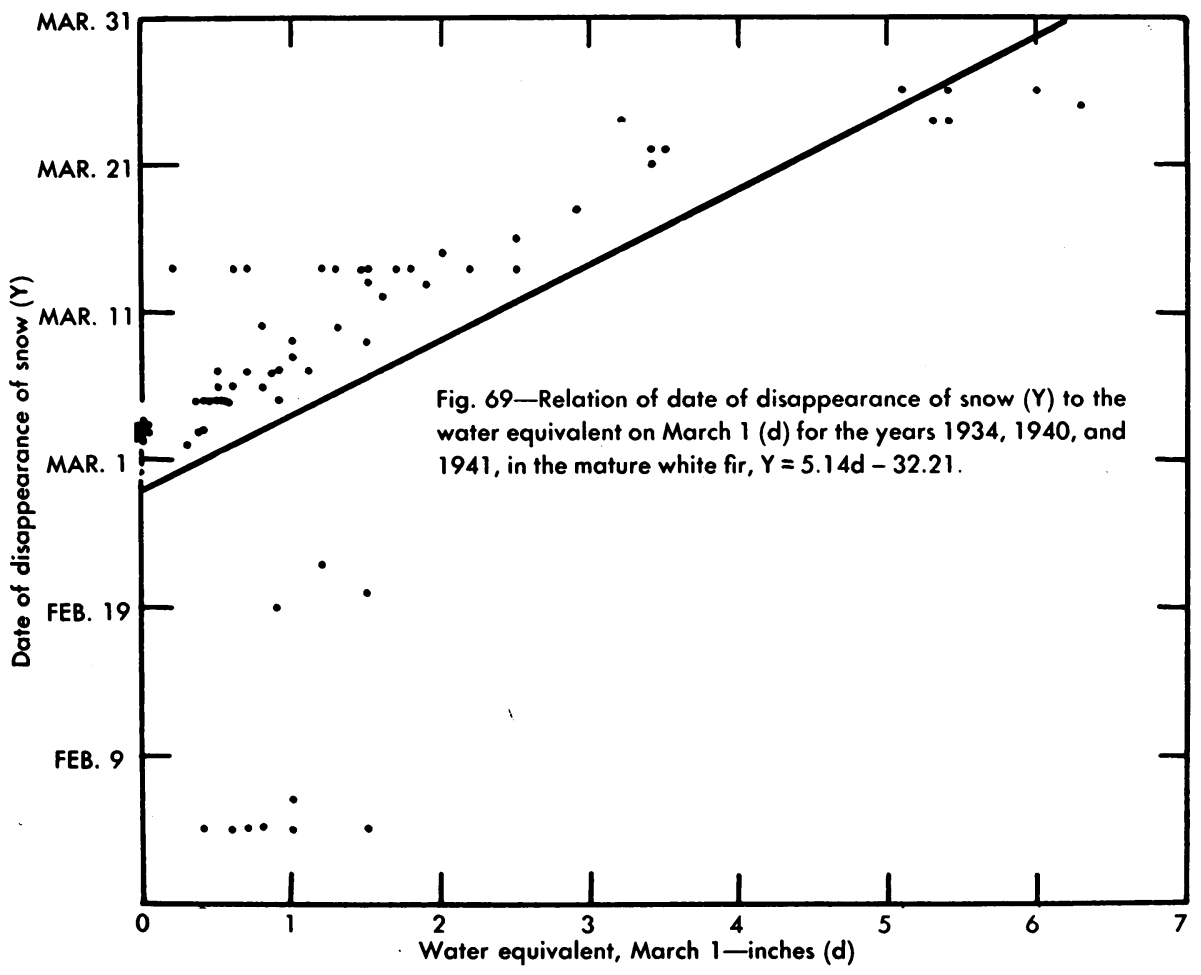

disappear first in the large open areas and in the old ponderosa pine, two or three days later in the open screened, young, dense ponderosa pine and in the cutover mixed conifer, seven days later in the old mixed conifer and in the white fir types, and 15 days later in the red fir. In the years 1934, 1940 , and 1941, if there were 3 inches water equivalent of snow on March 1, the dates of disappearance in the forested areas would be six to 10 days later than in the large clearing. Actually, the water equivalents on March 1 in the different types were not the same. In 1935-1938, the averages varied from 7.4, in the young ponderosa pine, to 20.4 in the red fir. The use of the actual averages in the equations would obviously change the foregoing comparisons, but would not so clearly indicate the influence of the different types of cover.

If the decreases in water equivalent from March 1 to disappearance are divided by the numbers of days derived from the equations of Table 26, a series of figures for average daily rates of decrease in water equivalent are obtained. These are given in Table 27 for certain assumed values of water equivalents on March 1. The sequence of types for the years 1935-1938 is necessarily the same as it was for the dates of disappearance in Table 26 . The range from the maximum in the meadow to the minimum in the red fir is only 0.06 inch. In seasons when the water equivalent on March 1 was 20 inches, the daily decrease was about 0.1 inch greater than in seasons when it was 10 inches. In general, the rate of decrease is greater as the time to 


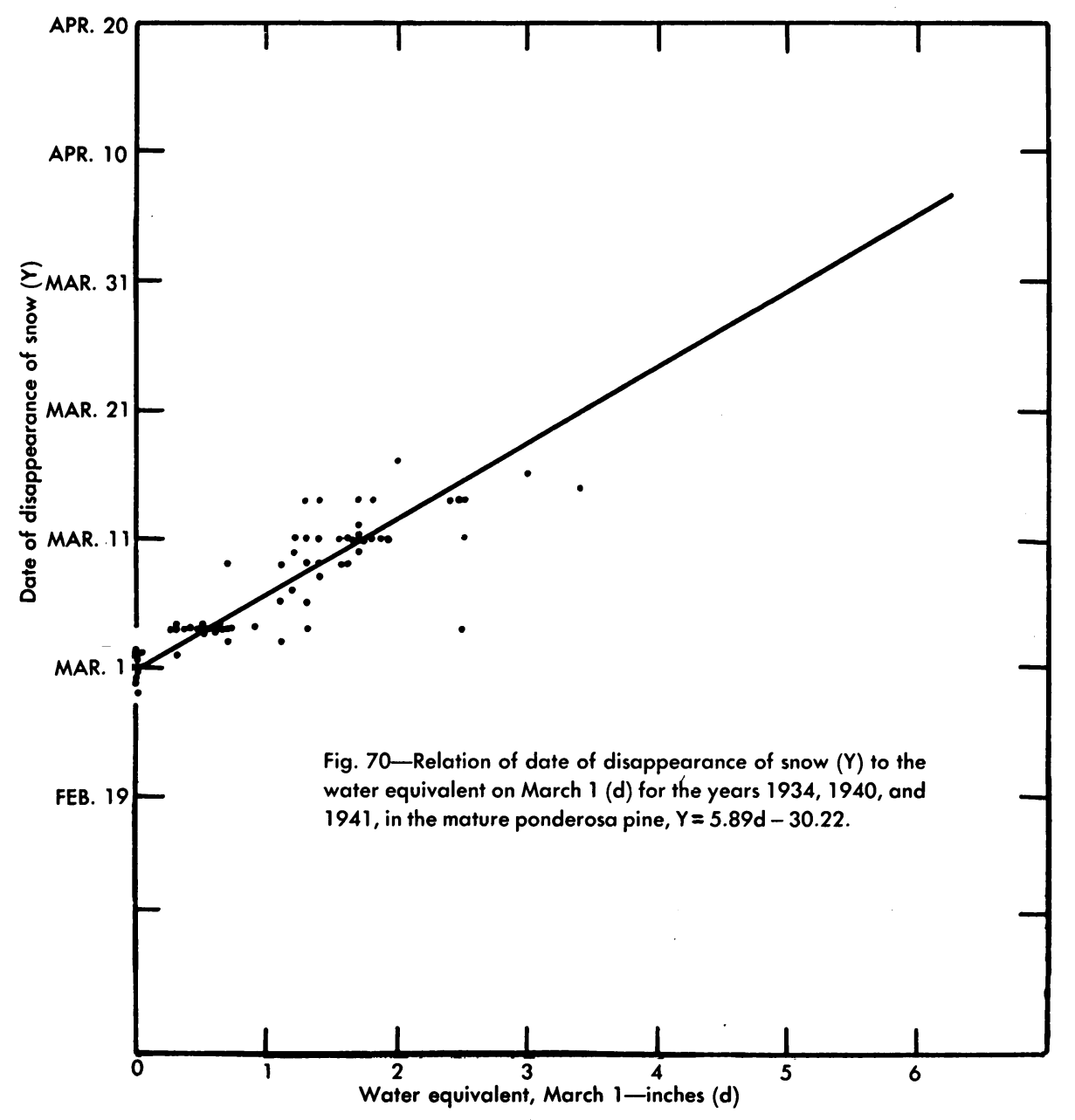

disappearance is longer, doubtless because the snow is exposed later to the higher temperatures of late spring or summer. The rates of decrease, which are approximately the rates of melting, vary from 0.16 to 0.40 inch water equivalent per day. The lower rates are in the denser stands of fir, and the higher in the ponderosa pine and large open areas. These rates are averages for the whole time from March 1 to disappearance, and include the effects of snow or rain which fell after March 1 . Hence they are lower than those derived from actual differences in water equivalents during periods without precipitation, as given in Table 28.

The median daily rates of decrease in water equivalent for the different conditions of cover (table 28) are separated into two periods each yearthe winter period before March 9, and the spring period from March 9 to the end of the snow season. In general, the snow tends to melt more rapidly with the advance of the season. However, the records plainly indicate a slow 
TABLE 26

DATES OF DISAPPEARANCE OF SNOW $(F)$ AS A FUNCTION OF THE WATER EQUIVALENT OF TOTAL SNOW ON THE GROUND ON MARCH $1(d)$, IN DIFFERENT FOREST TYPES

(Dates of disappearance are numbers of days after [or before] March 31)

\begin{tabular}{|c|c|c|}
\hline \multirow{2}{*}{ Forest type } & \multicolumn{2}{|c|}{ Regressions equations } \\
\hline & $\begin{array}{l}\text { Years of heavy snow: } \\
1935,1936,1937,1938\end{array}$ & $\begin{array}{c}\text { Years of light snow: } \\
1934,1940,1941\end{array}$ \\
\hline Mature ponderosa pine.......... & $Y=1.68 d^{*}-1.46$ & $Y=5.89 d \dagger-30.2$ \\
\hline Open meadow, $5,550 \mathrm{ft} .$. & $Y=1.68 d-1.30$ & \\
\hline Large clearing $\ldots \ldots \ldots \ldots \ldots$ & $Y=1.68 d \quad-0.94$ & $Y=1.90 d \ddagger-28.5$ \\
\hline Ponderosa pine, $14 \mathrm{ft}$. high.. & $Y=1.68 d \quad+0.62$ & $\ldots \ldots \ldots \ldots \ldots$ \\
\hline Open screened $\ldots \ldots \ldots \ldots$ & $Y=1.68 d+0.94$ & $\ldots \ldots \ldots \ldots \ldots$ \\
\hline Mixed conifer, cutover. . & $Y=1.68 d+1.07$ & $Y=4.52 d-27.5$ \\
\hline Sugar-ponderosa pine... & $Y=1.68 d+5.90$ & $\ldots \ldots \ldots \ldots \ldots$ \\
\hline White fir, mature........ & $Y=1.68 d+6.24$ & $Y=5.14 d-32.2$ \\
\hline 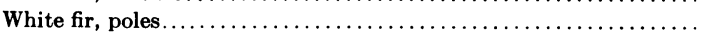 & $Y=1.68 d+6.96$ & $\ldots \ldots \ldots \ldots \ldots$ \\
\hline Red fir $\ldots \ldots \ldots \ldots \ldots \ldots \ldots \ldots \ldots \ldots \ldots \ldots \ldots \ldots \ldots \ldots \ldots \ldots \ldots \ldots$ & $Y=1.68 d+13.82$ & $\ldots \ldots \ldots \ldots \ldots$ \\
\hline
\end{tabular}

* Coefficient 1.68 is derived from data for all types combined because differences between types were not significant.

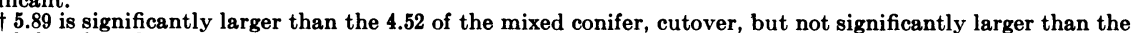
5.14 of the white fir, mature.

$\ddagger 1.90$ is significantly smaller than other coefficients for 1934-41, but not significantly larger than 1.68 of $1935-38$

TABLE 27

AVERAGE DAILY RATES OF DECREASE IN WATER EQUIVALENT OF SNOW

FROM MARCH 1 TO DISAPPEARANCE, IN DIFFERENT FOREST TYPES AND FOR SELECTED WATER EQUIVALENTS ON MARCH 1

\begin{tabular}{|c|c|c|c|c|}
\hline \multirow{3}{*}{ Forest type } & \multicolumn{4}{|c|}{ Average daily decrease in inches water equivalent* } \\
\hline & \multicolumn{2}{|c|}{$1935-1938$} & \multicolumn{2}{|c|}{$1934,1940,1941$} \\
\hline & $\begin{array}{c}\text { W. eq. Mar. } 1 \\
10 \text { in. }\end{array}$ & $\begin{array}{c}\text { W. eq. Mar. } 1 \\
20 \text { in. }\end{array}$ & $\begin{array}{c}\text { W. eq. Mar. } 1 \\
\text { in. }\end{array}$ & $\begin{array}{l}\text { W. eq. Mar. } 1 \\
4 \text { in. }\end{array}$ \\
\hline Old ponderosa pine............ & 0.22 & 0.32 & 0.16 & 0.16 \\
\hline Open meadow, $5,550 \mathrm{ft}$. & 0.22 & 0.32 & $\ldots$ & $\ldots$ \\
\hline Large clearing. $\ldots \ldots \ldots \ldots \ldots$ & 0.21 & 0.31 & 0.32 & 0.40 \\
\hline Ponderosa pine, $14 \mathrm{ft}$. high.. & 0.21 & 0.31 & $\ldots$ & $\ldots$ \\
\hline Open screened............. & 0.21 & 0.30 & $\ldots$ & $\ldots$ \\
\hline Mixed conifer, cutover... & 0.20 & 0.30 & 0.16 & 0.19 \\
\hline Sugar-ponderosa pine $\ldots \ldots \ldots \ldots \ldots \ldots \ldots$ & 0.19 & 0.28 & $\ldots$ & $\ldots$ \\
\hline White fir, mature $\ldots \ldots \ldots \ldots \ldots \ldots \ldots \ldots \ldots \ldots \ldots \ldots \ldots \ldots$ & 0.19 & 0.28 & 0.22 & 0.21 \\
\hline 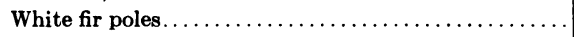 & 0.18 & 0.28 & $\ldots$ & $\ldots$ \\
\hline Red fir $\ldots \ldots \ldots \ldots \ldots \ldots \ldots \ldots \ldots \ldots \ldots \ldots \ldots \ldots \ldots$ & 0.16 & 0.26 & $\ldots$ & $\ldots$ \\
\hline
\end{tabular}

* Averages derived from the regression equations for date of disappearance as a function of water equivalent on March 1. 


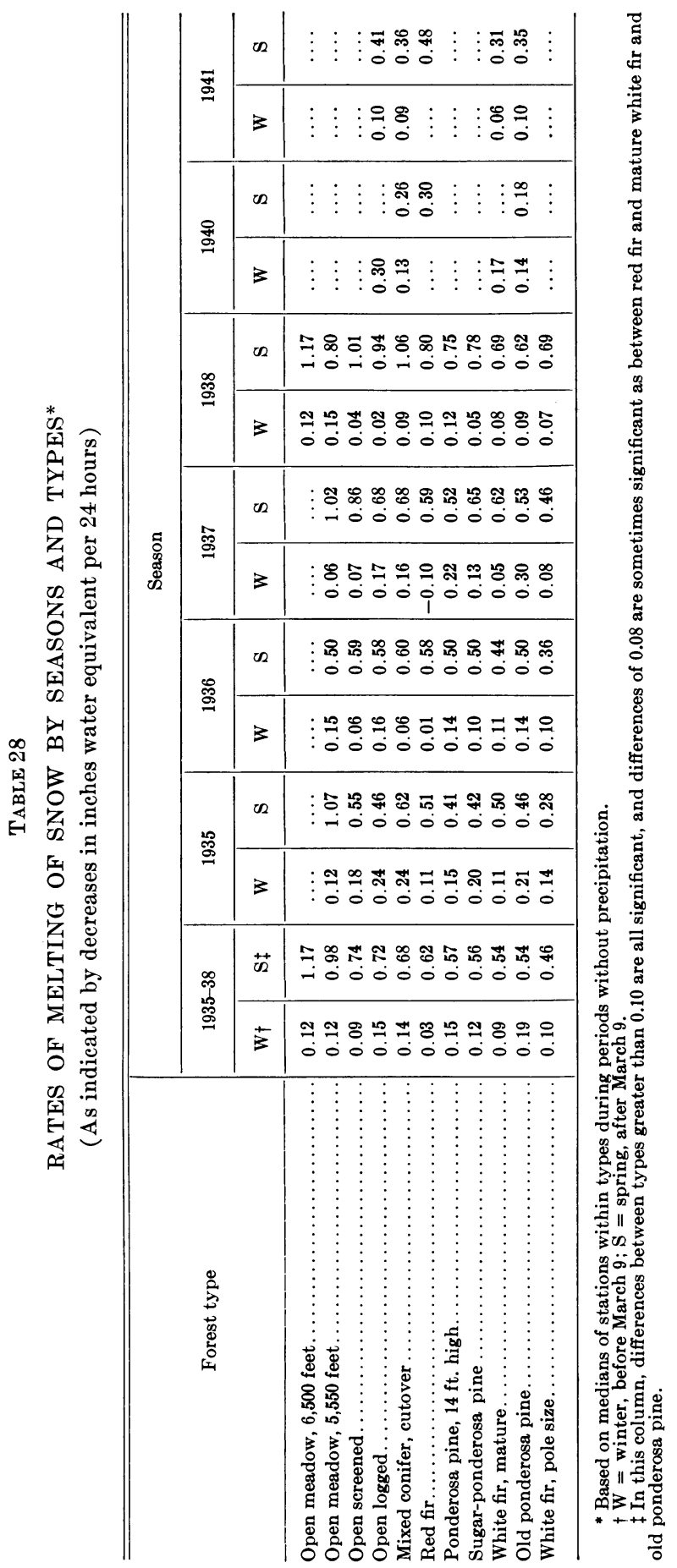


and irregular increase before March 9, related to the occurrence of occasional rains or warm, sunny days. After March 9, on the other hand, the rates are much more rapid, with infrequent exceptions. The progressive increase in rates during the spring does not invalidate the use of averages for purposes of comparison, but it should be realized that the rates of decrease after March 9 tend to be higher in May or June than in March or April. For the winter, the maximum rate of decrease in any type or year is 0.30 inch per day. The medians for 1934-1938 range from $0.03 \mathrm{inch}$, in the red fir, to 0.19 in the old ponderosa pine. After March 9, only three figures in any year are less than 0.30 inch, and the medians vary from 0.98 inch per day, in the meadow, to 0.46 in the pole white fir. At 9,500 feet, in Colorado, the maximum decrease for any week was 0.79 inch per day (30).

Comparing cover types, the three open areas showed the most rapid rates of melting- 0.72 inch or more per day-and the dense stands of white fir, the slowest- 0.54 inch or less. In the cutover mixed conifer, the snow melted at the rate of 0.68 inch per day, while in the uncut mixed conifer (sugarponderosa pine) the significantly lower rate was 0.56 inch. In Pennsylvania, on cut and burned areas, the melting rate was 0.51 inches per day, and under hardwood and hemlock 40 to 50 years old, it was 0.36 inches (19). In Colorado, "no substantial difference was detected between aspen and pine," but melting was more rapid on the open fields according to Dunford and Niederhof (12). At 9,500 feet on the Wasatch Plateau in Utah, in May, the melting rate in the open was 1.84 inches water equivalent per day, and under conifers, 1.20 inches (11). All rates in Table 28 are for periods without precipitation, and no allowance is made at this point for the increasing areas of bare ground as the spring advances. In general, the rate of melting decreased as the density of the cover increased although the red fir and old ponderosa pine are out of place in the sequence. These two discrepancies may be the result of differences in the season during which the snow is exposed. A larger part of the melting in the red fir took place late in the spring when the rate of melting was rapid, and much of the melting in the old ponderosa pine was early in the spring when the rates tended to be slow. Types in which the differences in rates of melting are less than 0.08 inch, and not significant, could be combined in groups, but such combinations would have little value. Differences between different years were large, as would be expected from consideration of climatic variations. The highest rates for all types were in 1938 when the accumulation of snow was the largest; the lowest, in 1940 and 1941, two years of light snow.

The rate of melting after March 9 increases with elevation (see table 28). Thus at the open meadow at 6,500 feet, in 1938, the rate of melting was 0.37 inch greater than at the meadow 950 feet lower. Similarly, on the red fir area at 6,260 feet, the melting averaged 0.08 inch greater than in the mature white fir 1,060 feet lower. These figures are for the whole snow season after March 9 and therefore represent longer exposures, by 31 and 29 days, in the later part of the spring season at the higher elevations (table 23). The rates of melting were high in May and June, and the difference in time of exposure is undoubtedly one cause of the higher rates at higher elevations.

The rates of melting on the southern exposures, that is, in the ponderosa 
pine types, are not higher than on northern exposures, but differences in amount of snow and season of exposure are not comparable and tend to obscure the effect of aspect of exposure.

Rates of decrease for periods of 1 to 3 days rarely exceeded 2 inches water equivalent in 24 hours, and most of them were less than 1 inch per day. The highest rates were usually in the last few days of the melting season as the shallow remnants of snow surrounded by bare ground disappeared. The maximum daily rate for any one week at Crater Lake, Oregon, was 1.78 inches water equivalent (42).

At the end of the snow season, the rates of melting and yields of water from the snow are, at first, increased. But as the amount of snow diminishes, exposing larger areas of ground, the rates and yields decrease. These effects may be illustrated by the following figures from the sugar-ponderosa pine type in the spring of 1935. As the proportion of snow-covered area decreases, the

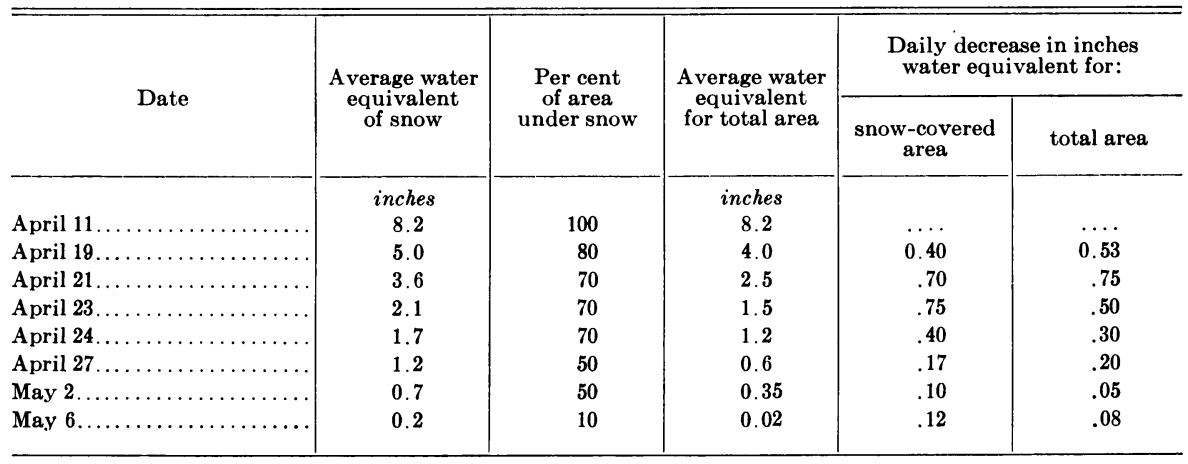

amount of water stored in the snow decreases more rapidly than is indicated by the water equivalents of the remaining snow. The rates of melting for the total area, including bare ground, are more rapid during the periods from April 11 to 21 and less rapid (with one minor exception) during the rest of the season. The most rapid melting rates of the whole snow season usually occur in the period soon after bare ground is first exposed.

Within stands of the same type, the rates of melting at stations under the crowns would be expected to be related to those in openings between the crowns or in large open areas. The relations were found to be represented by well-defined linear trends based on the data for all years combined. First, expressing the daily decreases in water equivalent in the openings between the crowns $(Y)$ in each cover type as a function of those in the large clearing $(X)$, highly significant regression coefficients were found for every type. The plotted points and trend lines are shown in figures 71-77. The coefficients, arranged in descending order of magnitude, and varying from 0.86 for the open screened area to 0.43 for the sugar-ponderosa pine, together with the $Y$-intercepts are given in Table 29. For the mature white fir, for example, the equation is $Y=0.66 X+0.01$. If the daily decrease in water equivalent in the large clearing were 1 inch, that in the openings between crowns in the forest would be 0.67 inch. The $Y$-intercepts are so small that the regression coefficients are only a little lower than the fractions of the daily rates in the large 


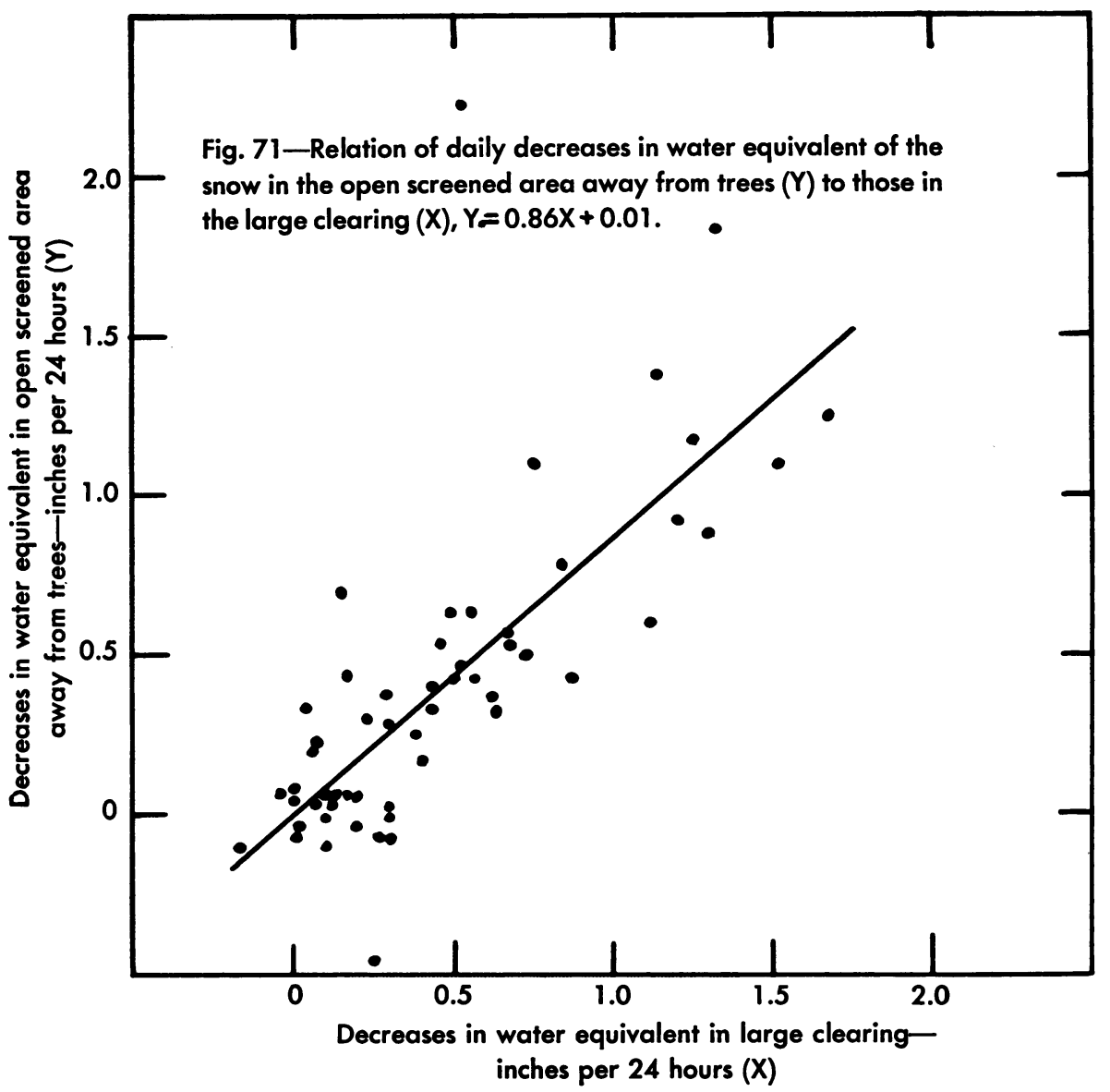

TABLE 29

DAILY DECREASES IN WATER EQUIVALENTS OF SNOW, IN INCHES PER 24 HOURS AT STATIONS IN THE OPENINGS BETWEEN CROWNS, AS FUNCTIONS OF THOSE IN THE LARGE CLEARING

\begin{tabular}{|c|c|c|c|c|c|c|c|c|c|}
\hline \multirow{2}{*}{ Forest type } & \multirow{2}{*}{$\underset{\text { intercept }}{Y-}$} & \multirow{2}{*}{$\begin{array}{l}\text { Regression } \\
\text { coefficient }\end{array}$} & \multicolumn{7}{|c|}{$\begin{array}{l}\text { Significance of differences between } \\
\text { regression coefficients }\end{array}$} \\
\hline & & & OS & PPM & $\mathrm{MCC}$ & WFM & PPR & WFI & SP-PP \\
\hline Open screened. . & 0.01 & 0.86 & $\ldots$ & $\ldots$ & $\ldots$ & $\ldots$ & $\ldots$ & $\ldots$ & $\ldots$ \\
\hline White fir, mature $\ldots \ldots \ldots \ldots \ldots$ & 0.01 & 0.66 & ns & ns & ns & $\ldots$ & $\ldots$ & $\ldots$ & $\ldots$ \\
\hline Ponderosa pine, $14 \mathrm{ft}$. high..... & 0.07 & 0.61 & ns & ns & ns & ns & $\ldots$ & $\ldots$ & $\ldots$ \\
\hline White fir, pole size $\ldots \ldots \ldots \ldots \ldots$ & 0.04 & 0.55 & s† & ns & ns & ns & ns & $\cdots$ & $\ldots$ \\
\hline Sugar-ponderosa pine . . . . . . . & 0.09 & 0.43 & hst & hs & $\mathbf{s}$ & $\mathbf{s}$ & ns & ns & $\ldots$ \\
\hline
\end{tabular}




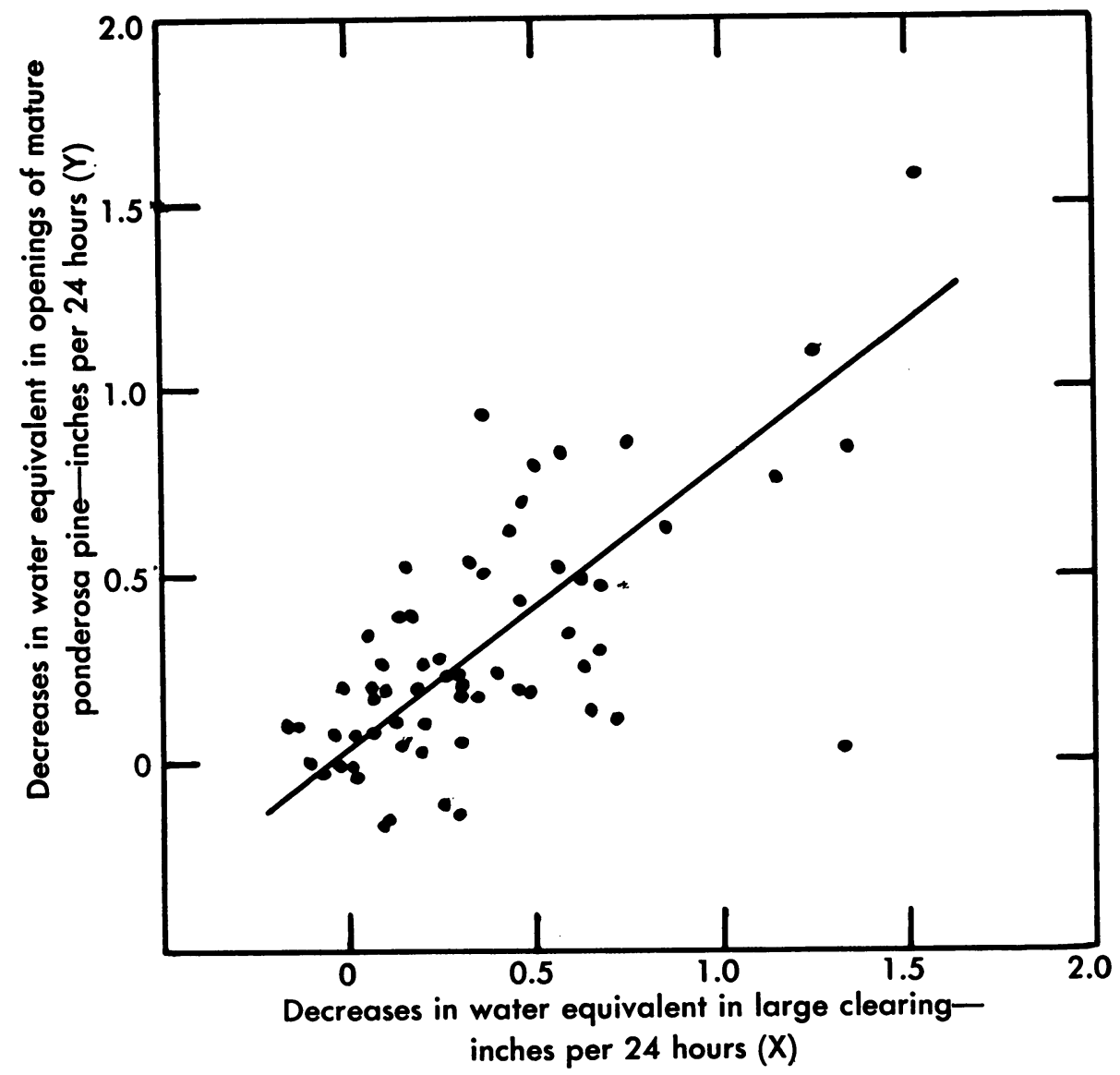

Fig. 72.-Relation of daily decreases in water equivalent of snow in the openings of the mature ponderosa pine $(Y)$ to those in the large clearing $(X), Y=0.76 X+0.04$.

clearing when the rates of melting are high. This is not true when the rates are low, as in winter. When, for example, a rate of 0.10 inch in the clearing would be less than the 0.13 inch in the sugar-ponderosa pine, the ratio would be 130 per cent when the regression coefficient would indicate 43 per cent.

When comparisons are made among types, there are significant differences in the regression coefficients of 0.86 for the open screened area and 0.55 and 0.43 for the white fir poles and sugar-ponderosa pine types, respectively. The coefficient of the latter is also significantly smaller than are those of the mature white fir $(0.66)$, mixed conifer cutover (0.72), and old ponderosa pine $(0.76)$. The relation for the sugar pine-ponderosa pine type to the large clearing is $Y=0.43 X+0.09$. When the open meadow is used as a basis for the regression, instead of the large clearing, the equation is $Y=0.42 X+0.12$, which is close enough to provide some confirmation for the values of the two constants. 


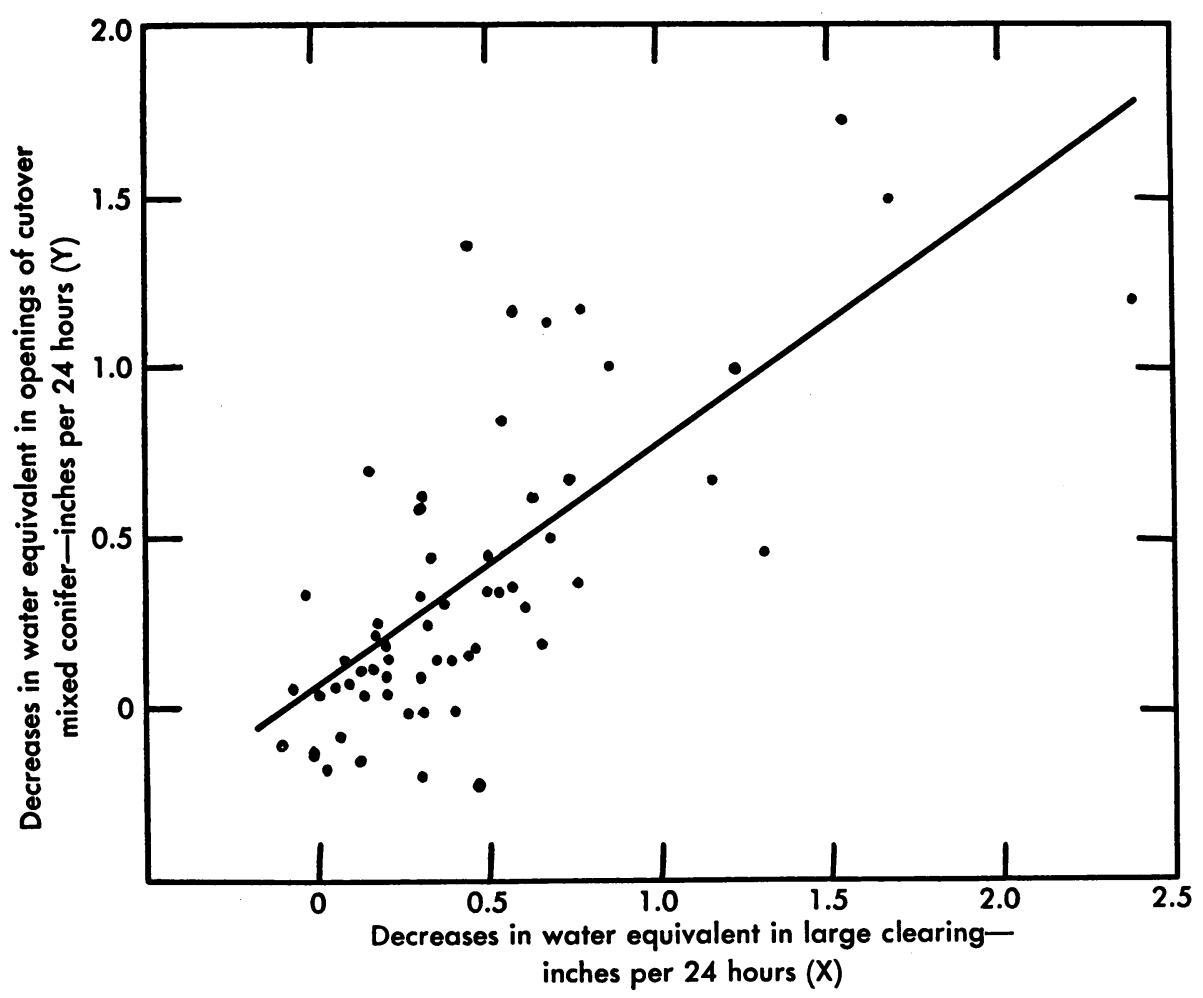

Fig. 73.-Relation of daily decreases in water equivalent of snow in the openings of the cutover mixed conifer $(Y)$ to those in the large clearing $(X), Y=72 X+0.06$.

Similarly, linear regressions of the daily decreases at stations under the crowns on those in the large clearing (table 30 ) also give highly significant coefficients for each type of cover. The sequence of magnitudes of the coeffcients differs from that in Table 29 only with respect to old ponderosa pine, which has a lower place in the ;list. The data and trend lines are given in figures 78-84. The $Y$-intercepts are somewhat more variable than in Table 29 and, for low rates of melting in the clearing, would, in some types, result in higher rates under the crowns. For a rate of melting of 1 inch per day in the clearing, the rate in the mixed conifer would be 0.88 and in the white fir, pole size, 0.57 , with intermediate values for the other types. Between types, the only significant differences in the coefficients are between the 0.77 for the open screened area and the 0.50 and 0.48 of the pole white fir and sugarponderosa pine, respectively.

The rates of melting derived from the equations of Tables 29 and 30 may be compared when the rate in the large clearing is constant at 0.5 inch, for example, to obtain the differences in melting between stations under the crowns and those in openings. The differences are more than 0.07 only in the open screened and mixed conifer cutover. In five out of seven of the types, the 


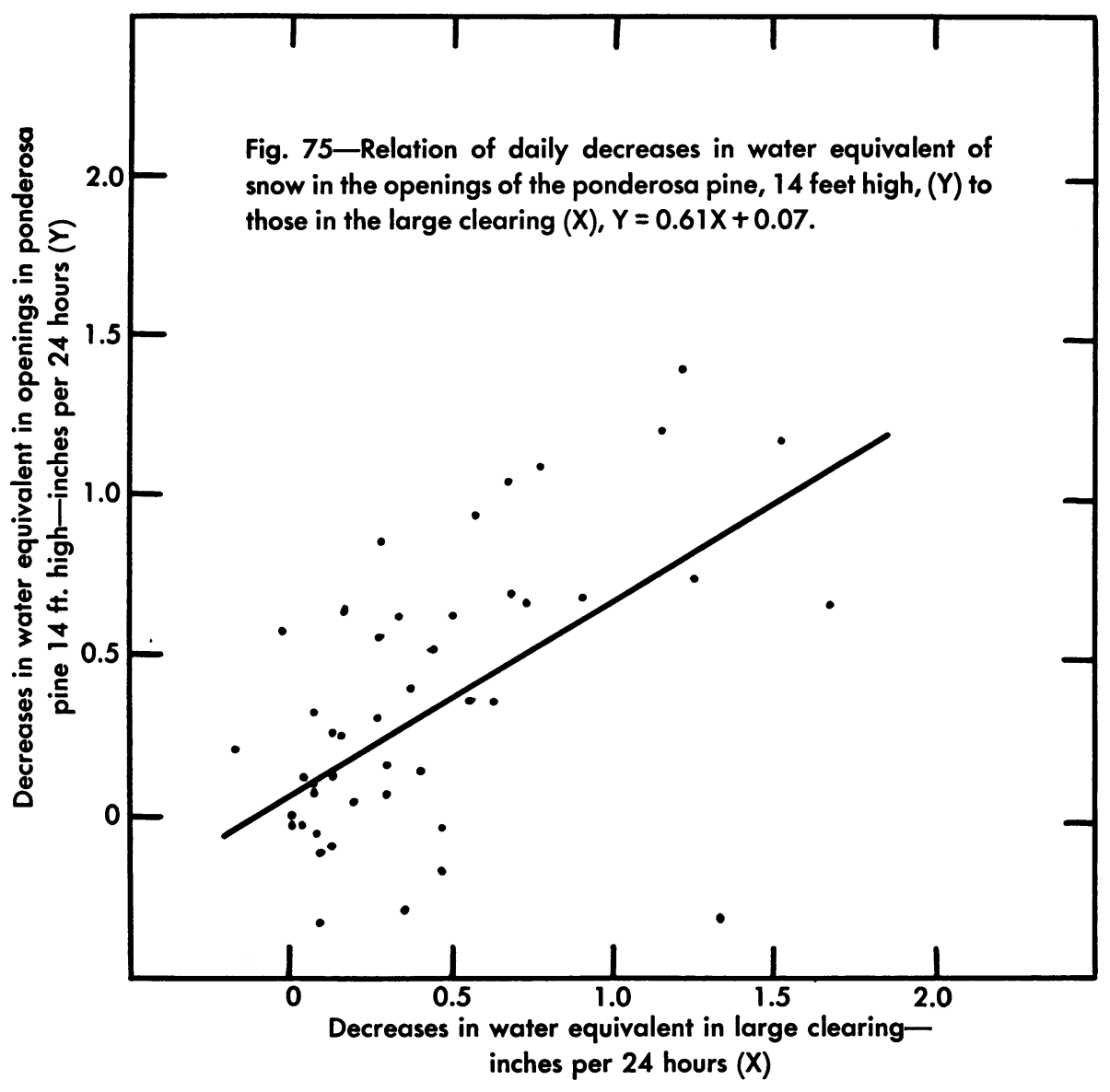

rates are higher under the crowns than in the openings. None of the differences between the two regression coefficients for the same type are significant. Apparently the openings between the trees in these stands are not large enough in relation to the heights of the trees to the south, for sufficiently greater amounts of solar radiation, wind, or turbulent mass exchange to affect the rates of melting any more than they do under the crowns.

As a check on this negative result derived from the relations to the melting in the large clearing, the daily decreases in water equivalent at stations under the crowns were plotted over those in the openings, for each type. Again linear trends were well-defined (figs. 85-92), and the regression coefficients were all highly significant. Table 31 contains the figures. All the coefficients, except for old ponderosa pine, are less than 1.0, indicating that the rates of decrease under the crowns are lower than those in the openings, per unit decrease in the openings. However, the positive values of the $Y$-intercepts add enough in the solution of the equations to make the computed rates of melting under the crowns not very different from those in the openings. If 


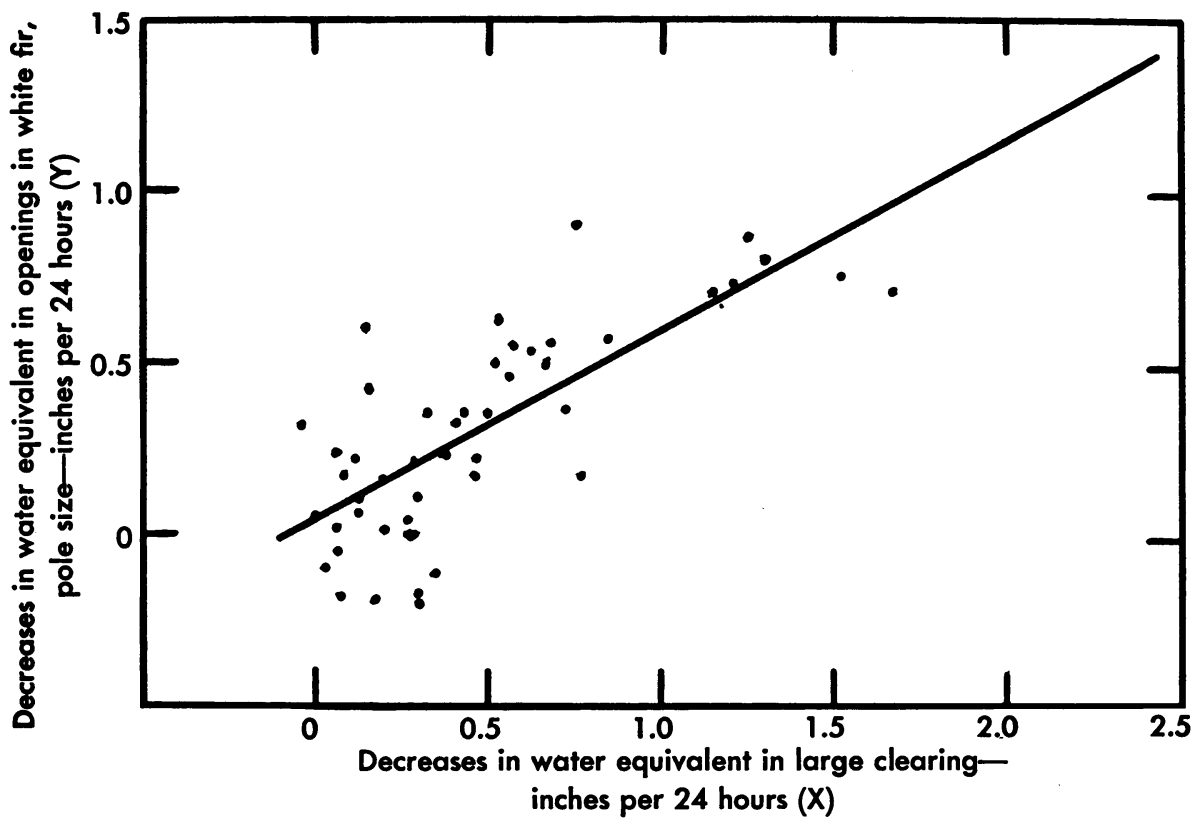

Fig. 76.-Relation of daily decreases in water equivalent of snow in the openings of the pole-size white $\mathrm{fir}(\mathrm{Y})$ to those in the large clearing $(X), Y=0.55 X+0.04$.

TABLE 31

DAILY DECREASES IN WATER EQUIVALENTS OF SNOW, IN INCHES PER 24 HOURS AT STATIONS UNDER CROWNS, AS FUNCTIONS OF THOSE IN OPENINGS BETWEEN CROWNS, BY FOREST TYPES

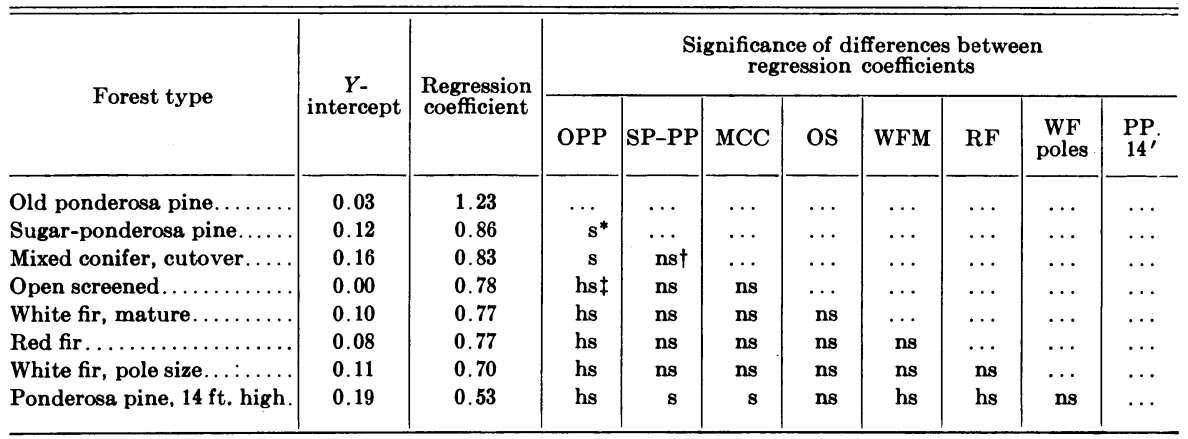

* $\mathrm{s}=$ significant.

+ ns= not significant.

$\ddagger$ hs $=$ highly significant. 


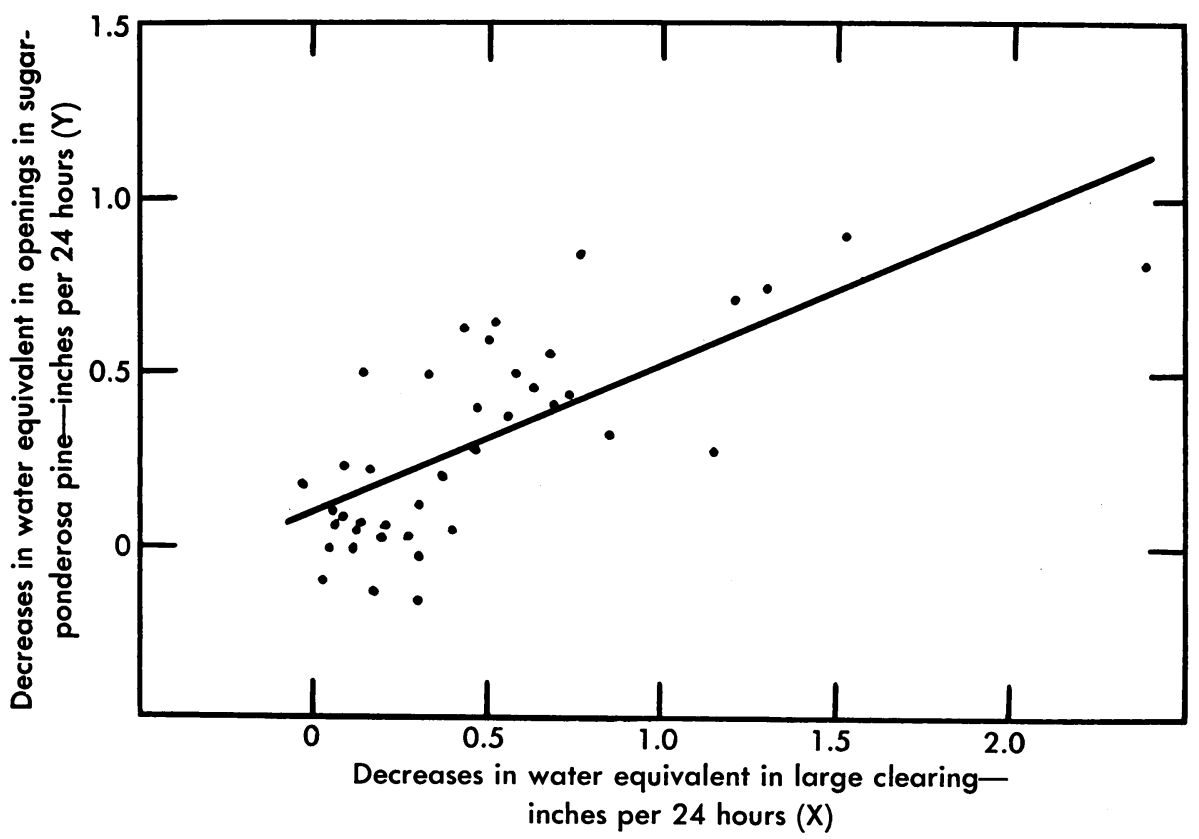

Fig. 77.-Relation of daily decreases in water equivalent of snow in the openings of the sugar pine-ponderosa pine $(Y)$ to those in the large clearing $(X), Y=0.43 X+0.09$.

the rate in the openings were $0.5 \mathrm{inch}$, four of the types would have lower and three, higher rates under the crowns. The old ponderosa pine would be highest, with 0.64 inch per day, and the open screened, lowest with 0.39 inch. The descending sequence of the coefficients in Table 31 suggests that they tend to become smaller as the density of the cover increases. However, the differences in the regression coefficients between types are only significant for the old ponderosa pine (1.23) and for the young ponderosa pine $(0.53)$ as compared with the 0.70 to 0.86 of the other types.

The foregoing three analyses show that the rates of melting under crowns can be estimated from those in the large clearing or in the openings between the crowns. Also, the rates in the openings can be estimated from those in the clearing. The rates tend to be lower under the crowns than in openings, and lower in the openings than in the clearing, per unit of change in the independent variable in each case. Actual differences in estimated values, however, are small and usually not significant either between crowns and openings or between cover types. The influence of the forest cover in retarding melting of snow is not so large as might be expected. In lodgepole pine and sprucefir in Colorado, it has been concluded that the rate of snow melt is not greatly increased by partial cutting (29).

Attempts to find significant relations between melting and the crown density, percentage of sunlight, distance from edge of crown or across openings, or the ratio of height of trees to the south to distance across openings 


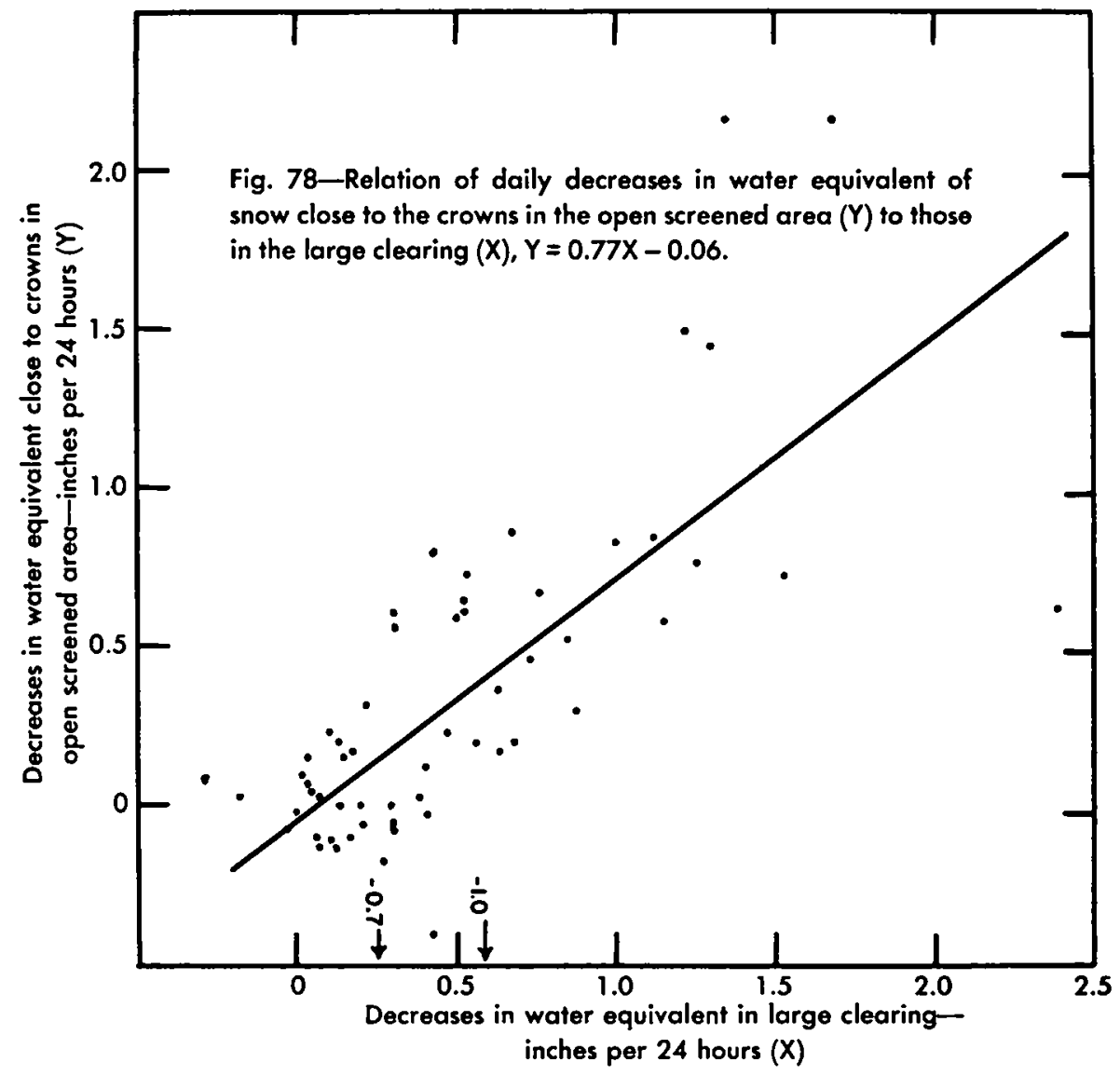

were unsuccessful, both for individual stations within stands and for averages of stands as units.

In a multiple correlation analysis, eight factors that might affect snow melt at 9,500 feet, in Colorado, were used as independent variables, namely, degree days above $32^{\circ} \mathrm{F}$, degree days above $50^{\circ} \mathrm{F}$, solar radiation, dew point temperatures, relative humidity, and wind velocities at 1.4, 24.9 feet above the surface in the forest and at 47.4 feet in the open (26). The factors that gave the highest multiple correlation coefficient $(0.74)$ were degree days above $32^{\circ}$, relative humidity, and wind velocity at 47.4 feet above the surface in the open. When solar radiation was included with these three factors, the coefficient was reduced, and in other combinations (with one exception), the partial regression coefficients for solar radiation were negative, indicating an inverse relation to snow melt for which an explanation is not obvious. At least, this suggests again that the direct effect of solar radiation is not so important in melting snow as is usually assumed. However, in areas of red fir, white fir, lodgepole pine, and in the open, in May and June in Plumas County, California, Colman ${ }^{s}$ found a linear relation

\footnotetext{
${ }^{9}$ From an unpublished report by E. A. Colman, with his kind permission.
} 


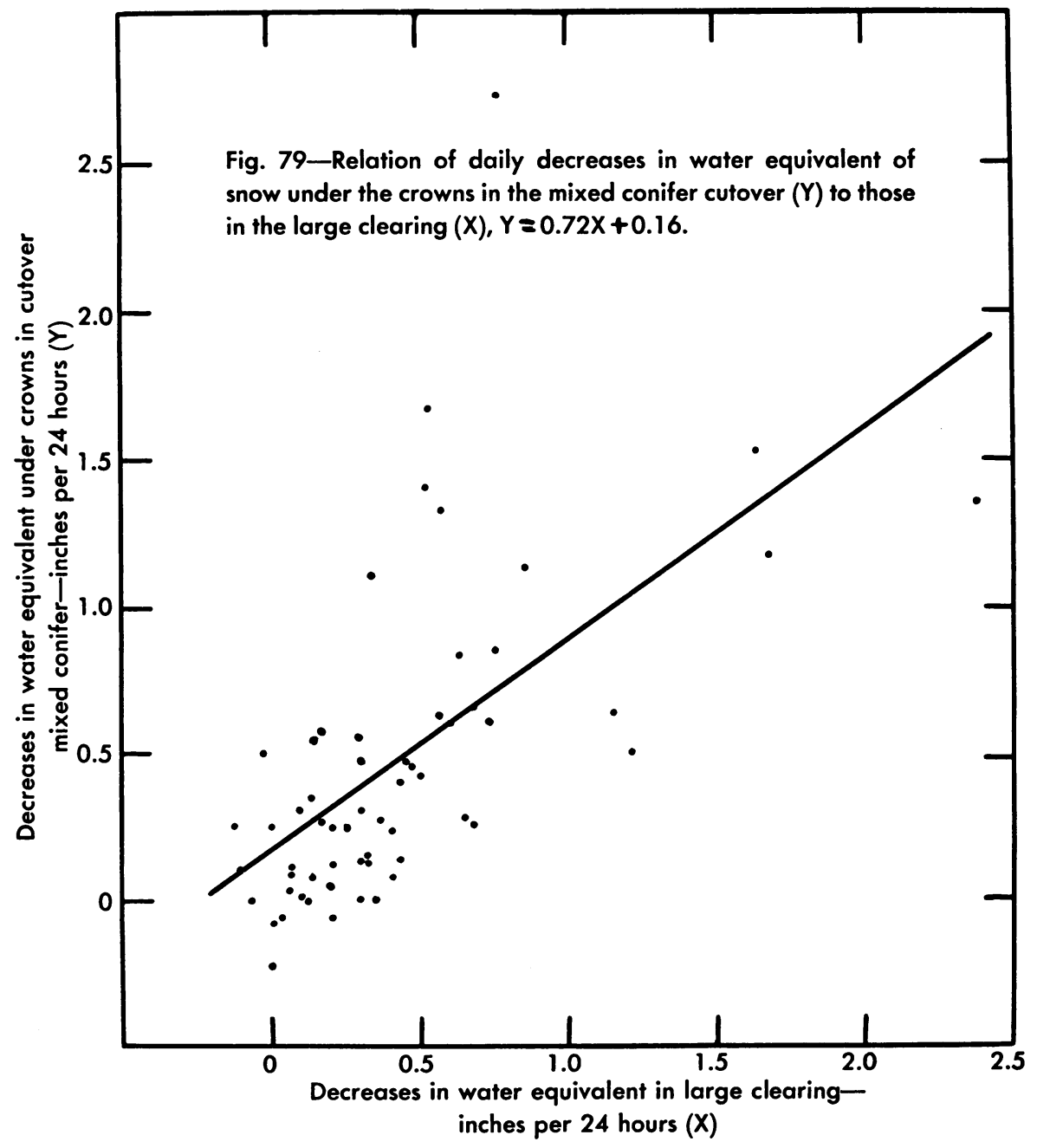

between average daily rate of melting in inches depth of snow $\left(D_{s}\right)$ and crown coverage in per cent $(c)$ which could be represented as $D_{s}=3-0.015 c$. The density of the snow at that time was about 50 per cent, so that the water equivalents would be one half the depths. The linear regression of rate of melting on percentage of insolation $(R)$ was less well-defined, but could be expressed as $D_{s}=2+0.011 R$.

The water from the melting snow was rarely observed to accumulate on the surface of the ground, and then only on flats or in depressions or channels. This would be expected when the rates of melting rarely exceeded 2 inches per day, and the loose sandy loam soils, 90 per cent covered with litter, had infiltration capacities of several inches per hour. Maximum melting rates, in Utah, of 1.97 and 3.50 inches per day are mentioned by Croft (11) as considerably exceeded by the infiltration capacities of the soil. 


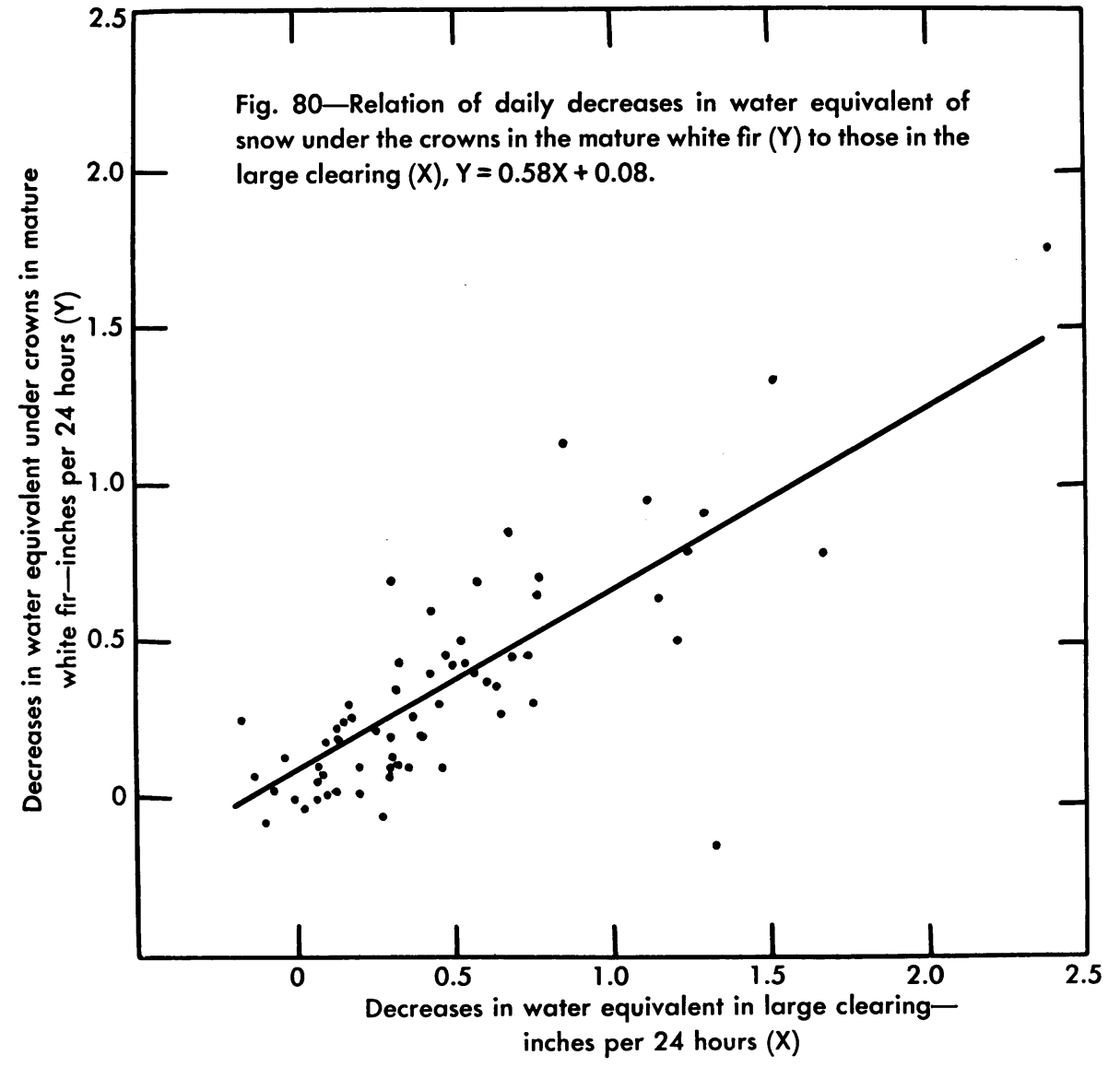

The excess of infiltration over rate of melting of snow was also indicated by records of ground water levels at two stations for the snow seasons of 1940 and 1941. The records were obtained by measuring the depth below the surface to the water level in well points once or twice a day. In the large clearing, in 1940, the ground water level was 19.1 inches below the surface on February 18, the date of the 3.4 inches maximum water equivalent of the snow, and was at the same level on March 6 when the snow disappeared. Not only had 3.4 inches of melt water entered the soil, but 7.7 inches of rain had also fallen in eight days without raising the water level. At the station in the old ponderosa pine, 2.6 inches of melt water plus the 7.7 inches of rain did not counteract a lowering of the ground water level by 0.1 inch. In 1941, the water level dropped from 27.8 inches to 28.7 inches below the surface, while 3.6 inches of snow melt plus 8.8 inches of rain entered the soil between February 9 and March 11. The ground water levels at these stations fluctuated less than 1.5 inches at any time during the snow seasons.

After the snow disappeared in 1940, the well point in the clearing that had shown minimum fluctuations was moved to a location in the old pon- 


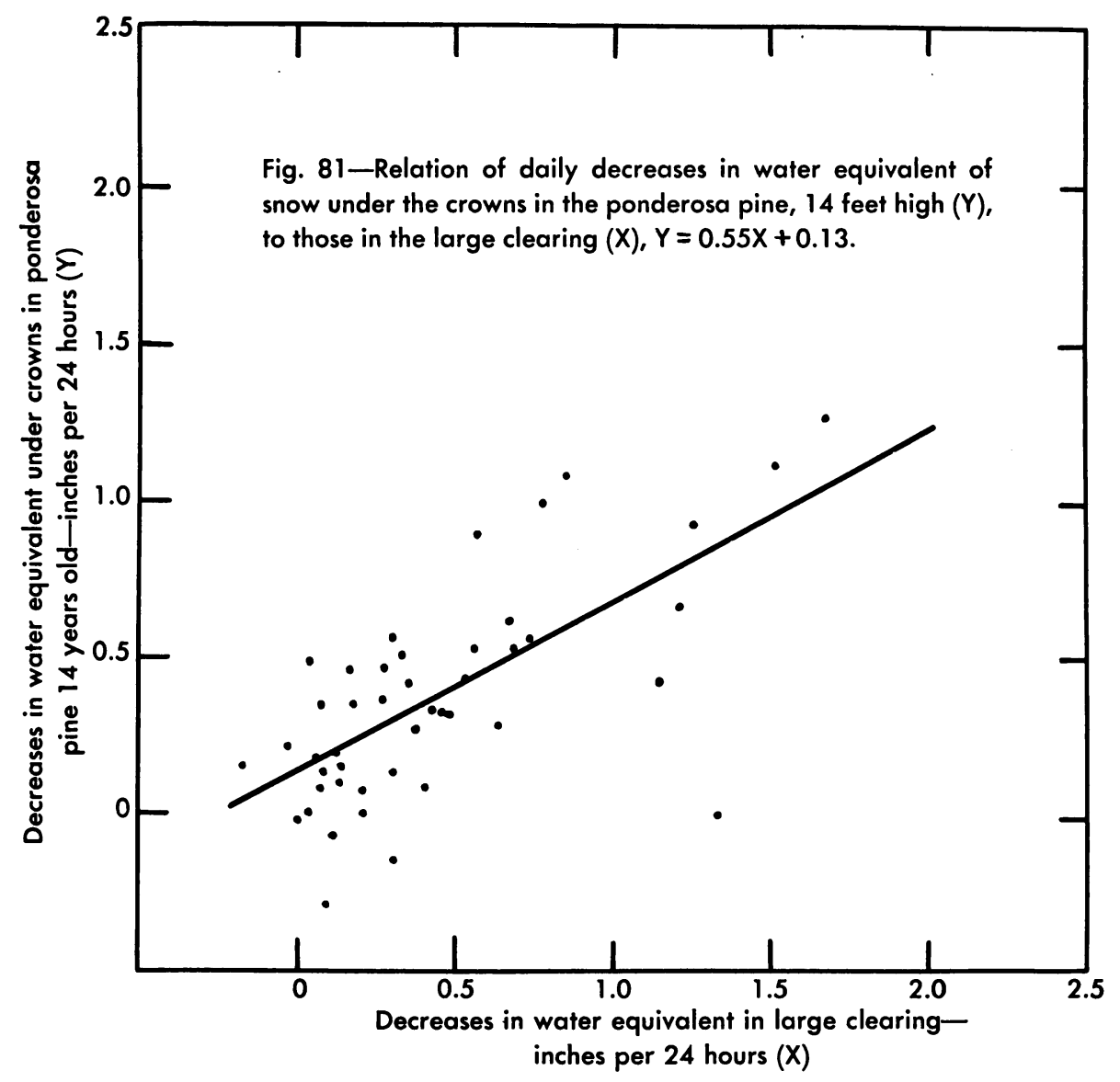

derosa pine about 8 feet from a draw which carried a small flow of water during the melting season. The ground surface at the well point was not more than 1 foot above the water surface in the draw. At this station, the ground water level rose sharply with each heavy rain, fell rapidly at first, and then more slowly until the next storm. However, the evidence of any effect of water from melting snow was entirely obscured, with one possible exception. In the five days before the snow disappeared on March 11, 1.9 inches of water passed into the soil. The water table dropped from 17.2 to 17.5 inches below the surface. In the subsequent five days without snow melt or rain, the drop was from 17.5 to 18.2 inches. The difference of 0.4 inch drop in five days may reflect the small effect of the 1.9 inches of water from the snow.

In contrast, storms of rain and snow caused sharp peaks, as in the examples in the tabulation on the opposite page.

At this station, the ground water level twice reached 11.4 inches below the surface as a maximum after heavy storms. At the other locations, the maximal levels were from 19 to 28 inches below the surface. It seems evident that the rate of melting of the snow did not exceed or equal the rate of infiltration or 


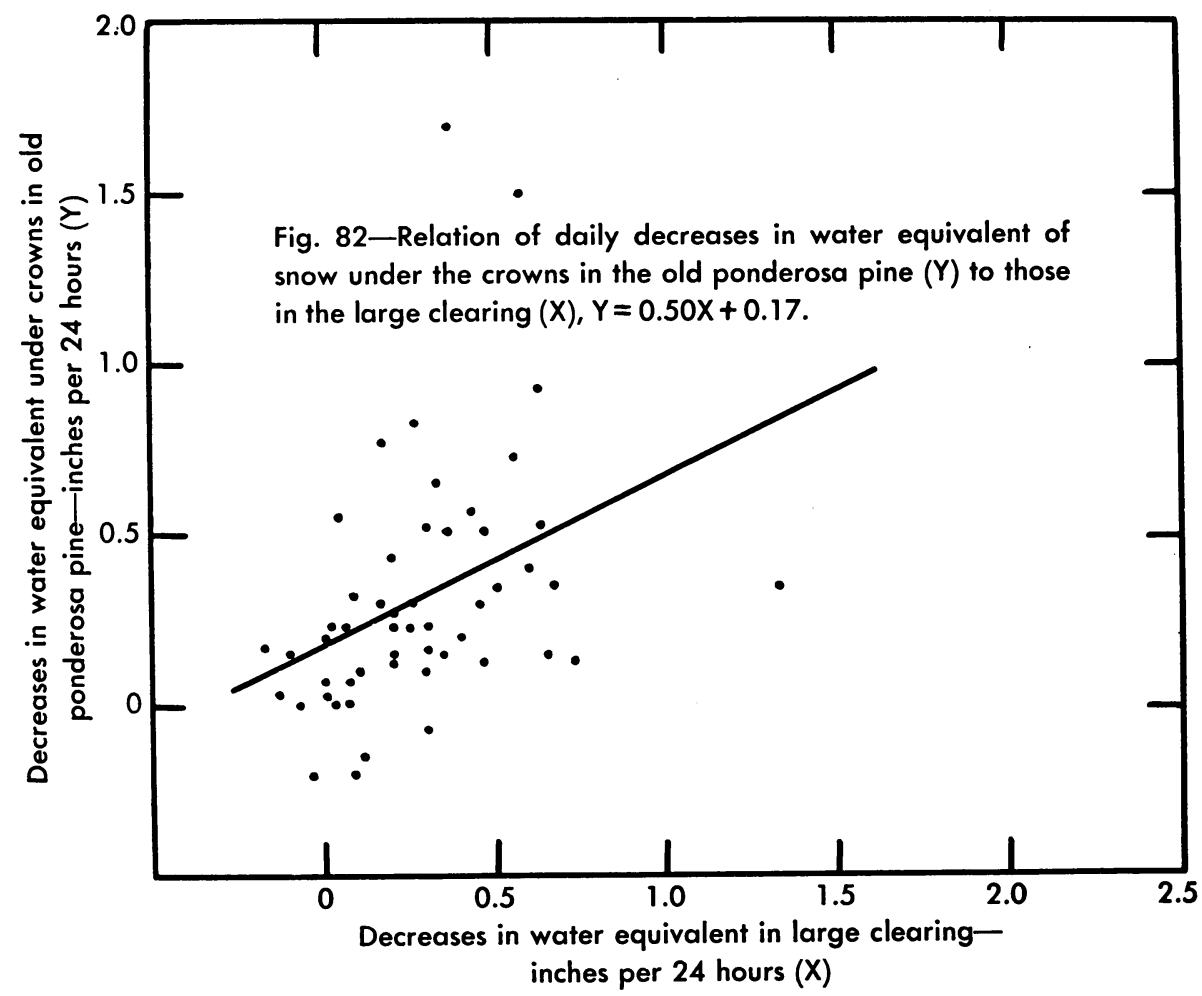

\begin{tabular}{|c|c|c|c|}
\hline Dates & Precipitation & $\begin{array}{c}\text { Rise in } \\
\text { water level }\end{array}$ & $\begin{array}{c}\text { Fall in } \\
\text { water level } \\
\text { in next } 3 \text { days }\end{array}$ \\
\hline April $2-5,1941 \ldots$ & $\begin{array}{c}\text { inches } \\
1.96\end{array}$ & $\begin{array}{c}\text { inches } \\
2.5\end{array}$ & $\begin{array}{c}\text { inches } \\
1.6\end{array}$ \\
\hline January $3-7,1941 \ldots \ldots \ldots \ldots$ & 2.15 & 4.2 & 1.5 \\
\hline February 28-March 4, 1941.. & 2.45 & 6.6 & 4.5 \\
\hline January $21-25,1941 \ldots \ldots \ldots$ & 2.49 & 3.2 & 1.1 \\
\hline February $8-11,1941 \ldots$ & 3.63 & 6.3 & 6.1 \\
\hline March $24-30,1940 \ldots \ldots \ldots \ldots$ & 8.75 & 7.7 & 2.5 \\
\hline
\end{tabular}

subsurface flow in these soils by a large margin and did not, by itself, cause surface runoff.

The magnitudes of rates of melting are confirmed, in general, by the daily records of streamflow in the locality. For the comparison, the daily discharge records of the U. S. Geological Survey (31) for Cherry Creek near Hetch Hetchy were used. The gaging station is at an elevation of 4,800 feet, about 7 miles south of the snow stations, and the stream drains 111 square miles of area similar to that where the snow was measured, but including a part at higher elevations. Records for all seven years of the snow measurements were available, and there were no reservoirs or diversions above the gaging station. The discharge records for the South Fork of the Stanislaus River above Strawberry, including much of the area of the snow records, covered only the 


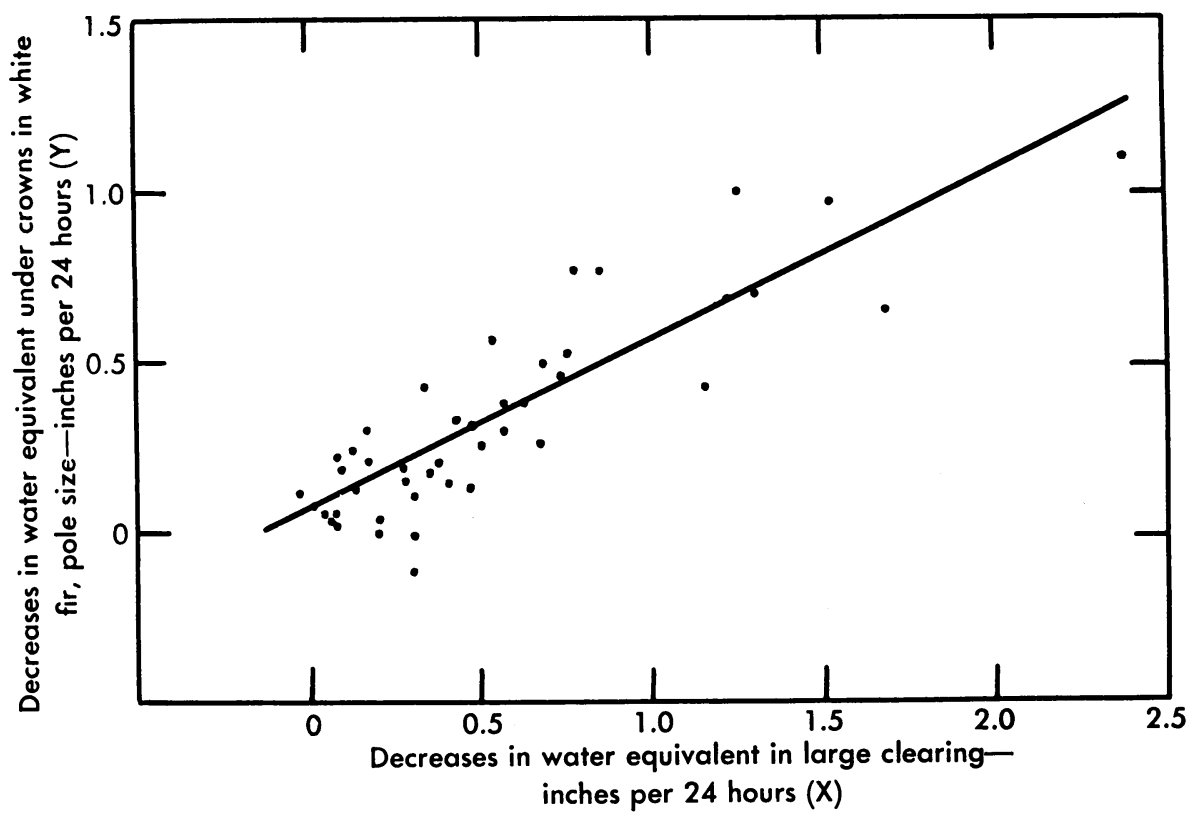

Fig. 83.-Relation of daily decreases in water equivalent of snow under the crowns in the polesize white fir $(Y)$ to those in the large clearing $(X), Y=0.50 X+0.07$.

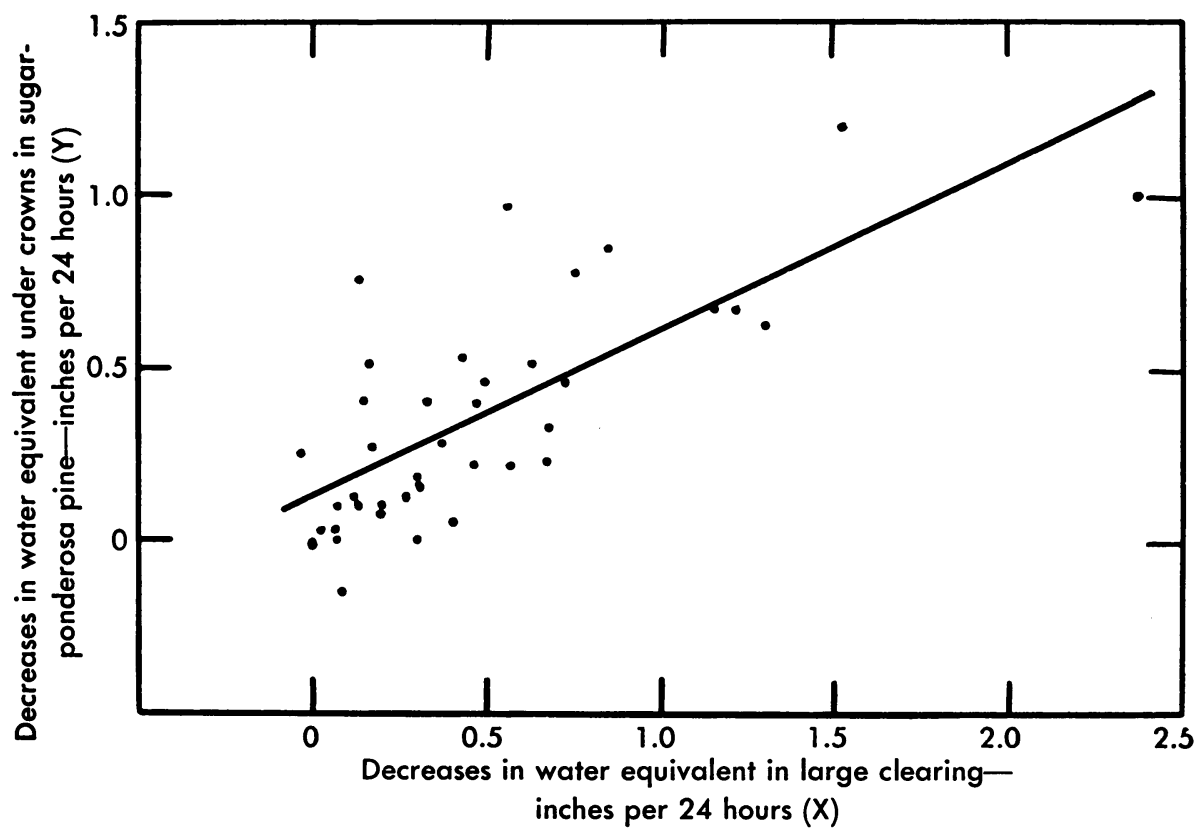

Fig. 84.-Relation of daily decreases in water equivalent of snow under the crowns in the sugar pine-ponderosa pine $(Y)$ to those in the large clearing $(X), Y=0.48 X+0.13$. 


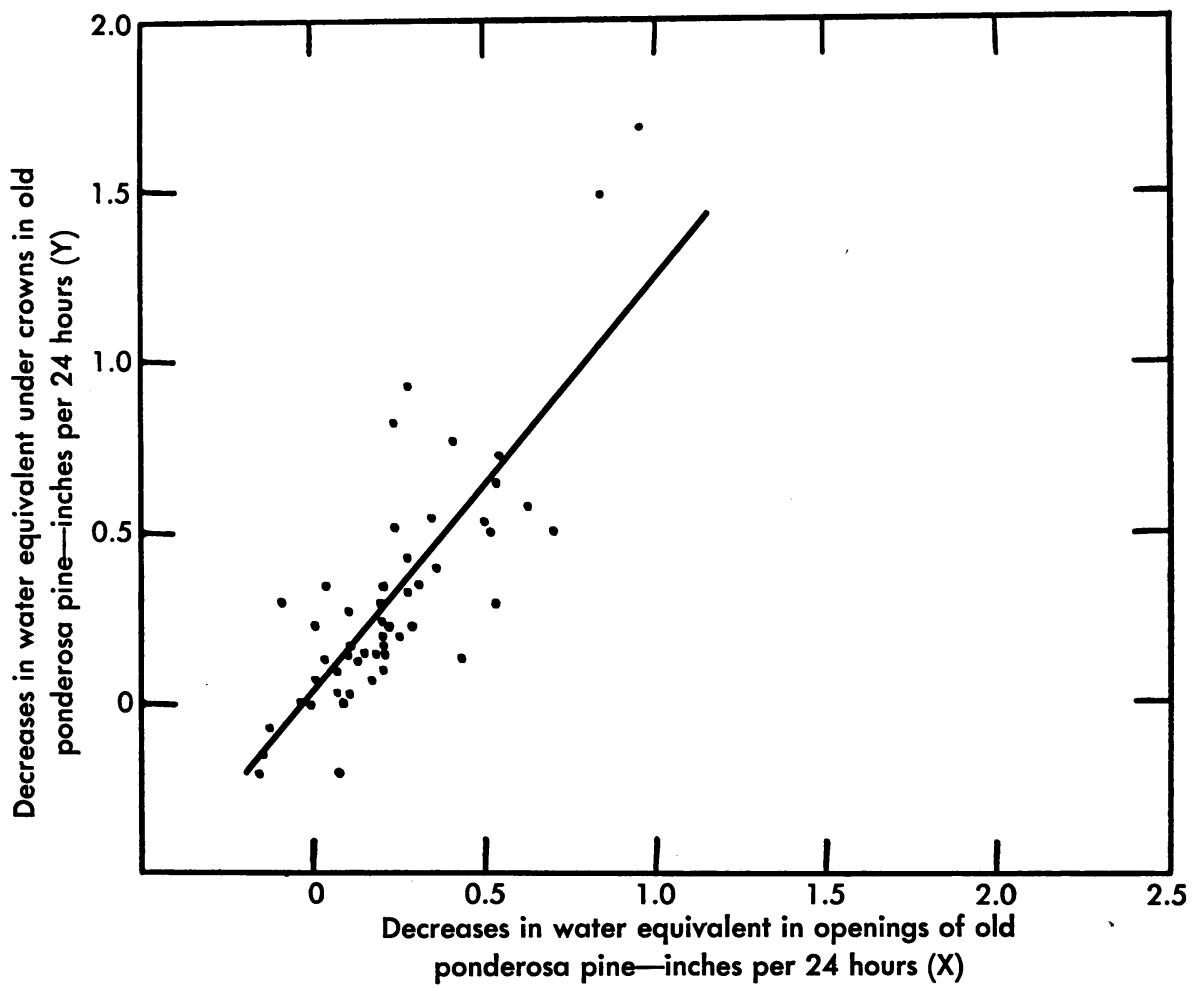

Fig. 85.-Relation of daily decreases in water equivalent of snow under crowns $(Y)$ to those in openings between crowns $(X)$ of old ponderosa pine, $Y=1.23 X+0.03$.

years 1940 and 1941, and fluctuations in flow for parts of the season were obscured by the controlled storage in Strawberry Reservoir. In periods free of control, the amounts of discharge were a little lower, but comparable with those in Cherry Creek. The high flows from melting snow usually occurred in May and June, and for those months the mean daily discharge varied from 0.48 to 0.66 inch in different years. The maximums for any one day in a year ranged from 0.41 to 1.13 inches. These amounts correspond well with the daily rates of melting after March 9,1935 , of from 0.28 to 1.07 inches, given in Table 28. However, the peak discharges occurred usually between May 12 and June 7, dates more than 30 days after all snow had disappeared in some years and in some types of the study area. This lag is largely attributable to the higher elevation of part of the Cherry Creek basin so that the snow lasts longer and melting continues later than at the lower elevations where the snow was measured. The ablation May 1 to 13, 1946, at the Central Sierra Snow Laboratory, ranged from 0.5 to 1.8 inches per day, with an average of 1.36 inches, which corresponded well with stream discharge of 1.41 inches per day (32).

The discharge rates include the effects of some rains, which are not dis- 


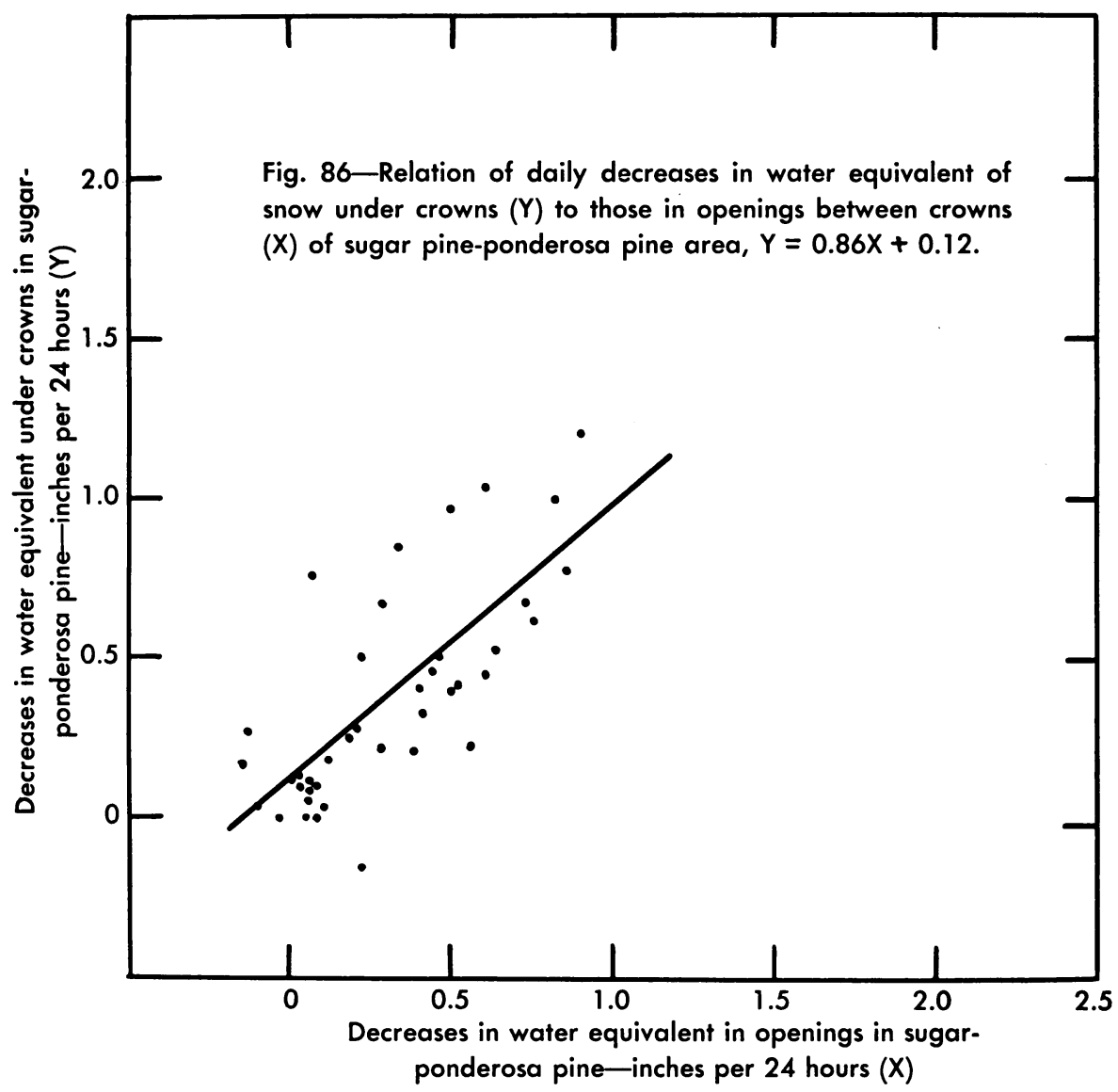

tinguishable from the effects of melting snow. Rains of 2 inches or more in the winter, while melting is small, may cause sharp peaks in discharge. Thus in 1941, the 2.45-inch storm of February 28 to March 4 caused a rise from 0.07 to 0.17 inch discharge per day in Cherry Creek. The 3.63-inch storm of February 8 to 11 caused an increase from 0.06 to 0.27 inch per day. In the big storm of December 9 to 12, 1937, 12.41 inches of precipitation, of which 6.54 inches fell on December 10, caused a flood flow of 3.88 inches per day on December 11, whereas the flow on December 9 had been only 0.09 inch. Thus heavy rains produce much higher flood peaks than does the melting of snow, whether in forested or in open areas. A similar conclusion, that mean daily discharge from rain often exceeded that from melting snow, was reached by Croft (11) working in the Wasatch Mountains of Utah.

\section{APPLICATIONS IN FOREST MANAGEMENT}

Snow, and the water from it, are factors to be considered wherever spring floods or yields of water for human use are important. That includes the whole west slope of the Sierra Nevada mountains, where the findings in this 


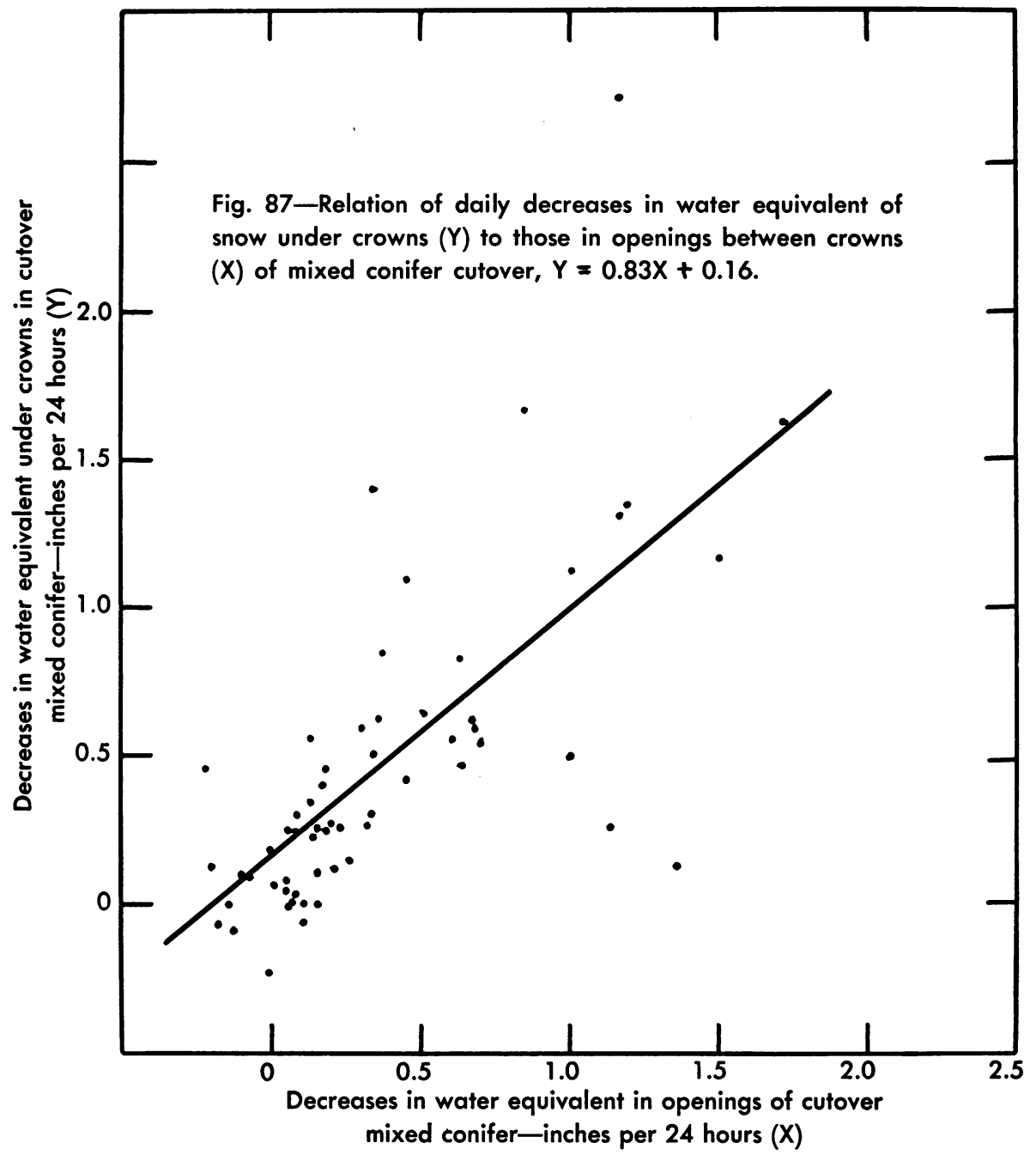

study, at least in part, should be applicable. Damaging flood peaks in this area are not the results of melting snow alone. The water from melting snow wets the soil and increases streamflow, but the melting is not sustained at a rate sufficient to cause appreciable surface runoff or serious flood crests. It does cause moderately high flows from April to June, and when heavy rains fall in this period to supplement the water from the snow, the snow must be considered a contributing factor in the resulting floods. It has been shown that the rates of melting are less under forest than in the open, and tend to decrease as the density of the forest increases. Therefore, maintenance of a dense forest cover will tend to minimize the rate of melting and hence reduce the contribution to flood flows if and when rains occur. The daily rate of melting might be 0.1 inch of water lower in a forested than in an open area. 


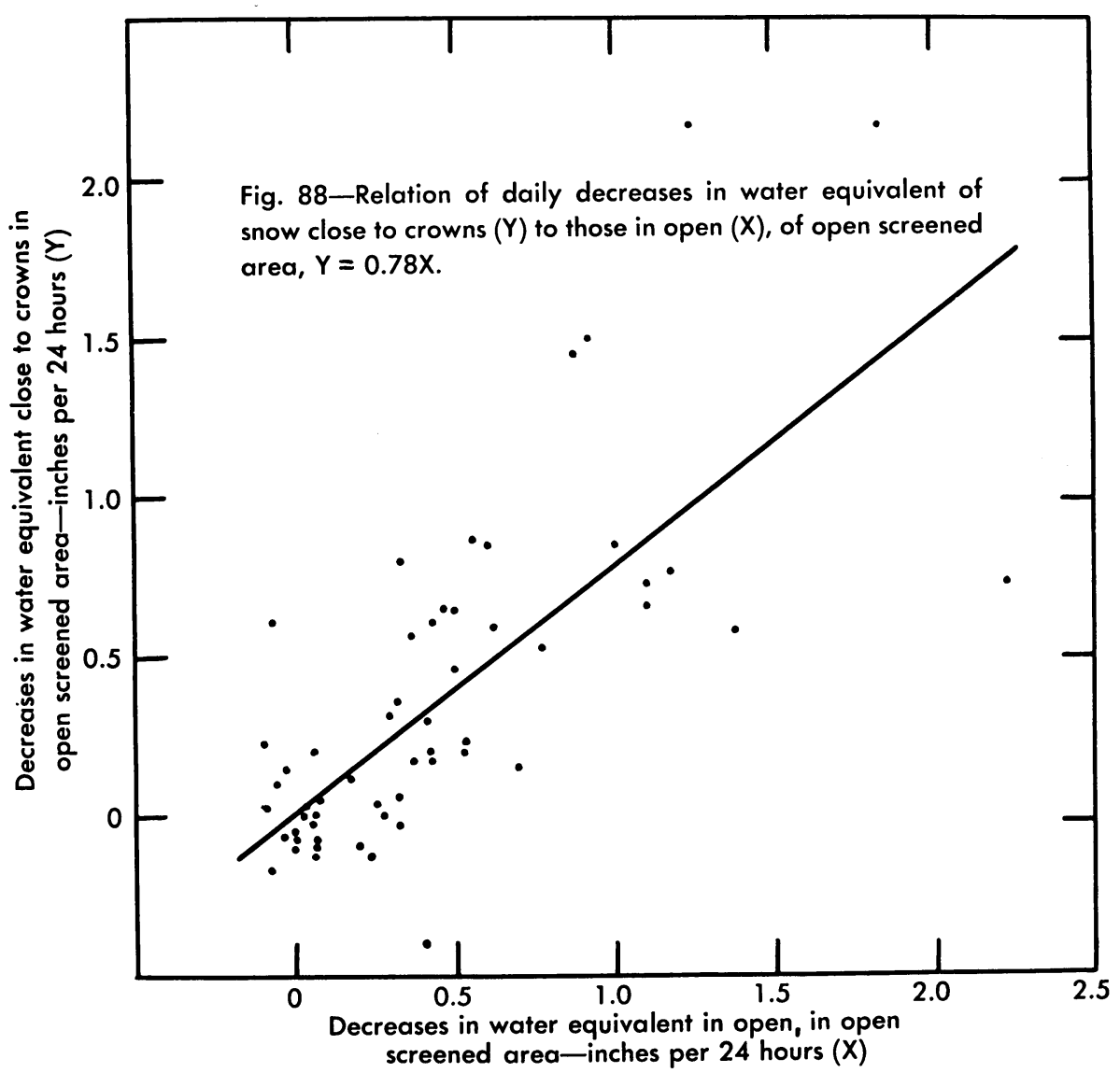

In the Cherry Creek drainage, this difference would correspond to a reduction of 0.4 foot in gage height during flood flows. In silvicultural terms, cuttings should be light, either by the selection system or by clear cutting in narrow strips or small groups which do not exceed once or twice the height of the residual stand. Dunning's unit area control system is a promising method of this kind $(16)$.

The snow is much more important in relation to yields of water than to floods. Throughout the San Joaquin Valley, more water is needed, and it is needed more urgently as summer progresses and streamflow declines. Therefore, the objectives in watershed management will be maximum total yields of water and prolonged flows from melting snow. Maximum yields of water will result if a maximum amount of snow accumulates on the ground and if the losses of snow or of water from the snow are kept to a minimum. The fact that more snow is found in openings in the forest than under the crowns or in deforested areas indicates that maximum amounts of snow will be trapped in a forest with many openings once or twice the height of the trees in width. Such a forest, on the basis of comparisons between cutover mixed conifer and 


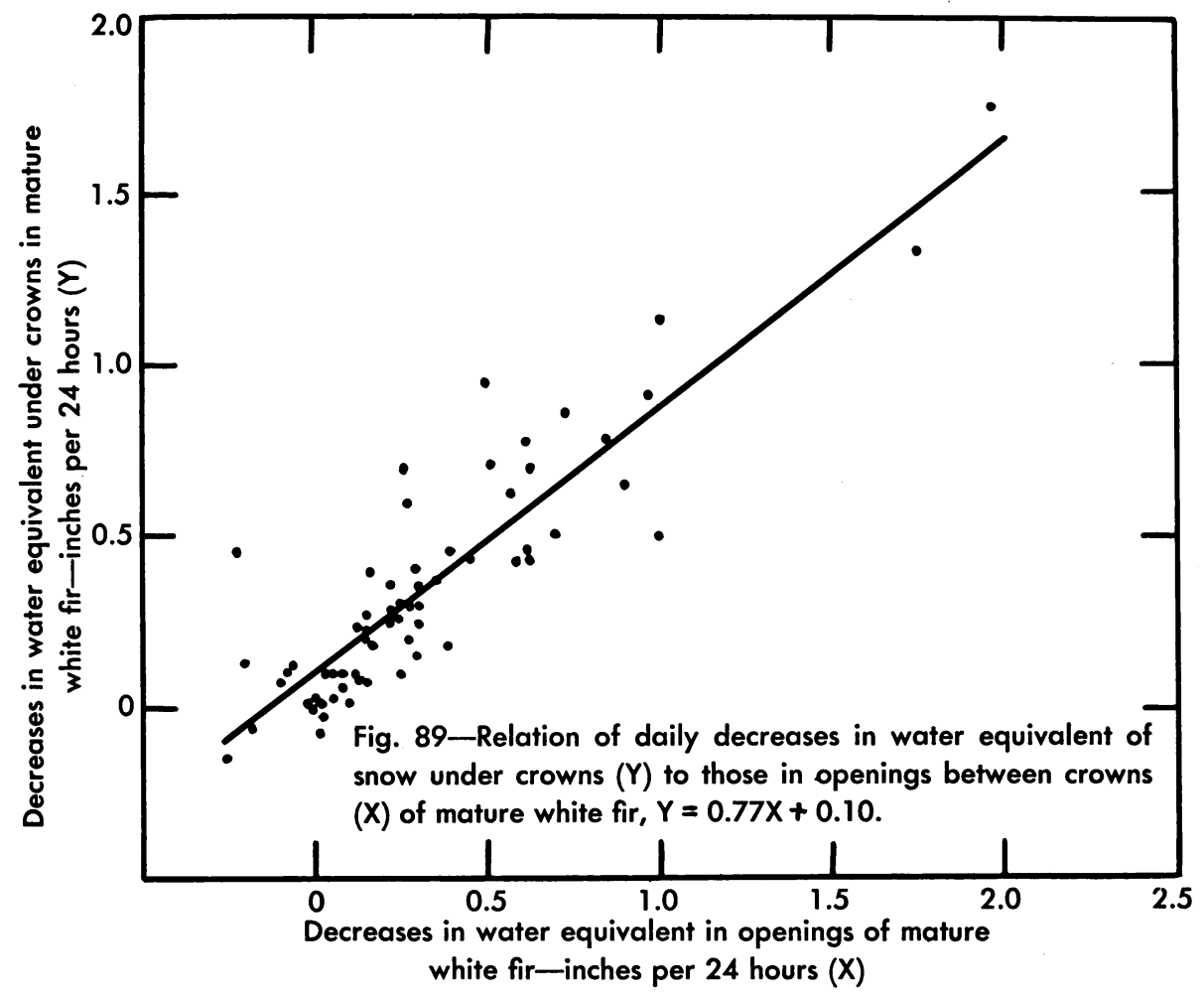

mature white fir in Table 15, could be expected to have 2 or 3 inches more water in storage as snow. If the comparison between water equivalents under crowns and in openings in the cutover mixed conifer (table 15) is used as a basis for an estimate of the additional snow after cutting, there was an average of 5.1 inches more in the openings. If the openings occupied 60 per cent of the area, there would be 3.1 inches more water stored in the snow on the area as a whole. In some years, as in 1937 when the difference between openings and under crowns was 8.2 inches, the additional storage would be 4.9 inches water equivalent. Both of these estimates were derived from a cutting which was not designed to trap maximum amounts of snow. A silvicultural treatment for that purpose should be decidedly more effective. Unfortunately, an example of such a cutting was not available, but a rough idea of the result can also be obtained from the differences between maximum and minimum water equivalents on the dates, usually in March or April, when the differences were greatest. These differences, in the cutover mixed conifer area where the openings most nearly approached a desirable size, varied from 5.6 to 27.0 inches in different years, with an average of 15.7 inches water equivalent. In creating, by cutting, the most effective openings to trap snow, it should be possible to convert part of an area from the condition of minimum accumulation where the stand is dense to that of maximum accumulation in openings once or twice the height of the trees in width. If that conversion 


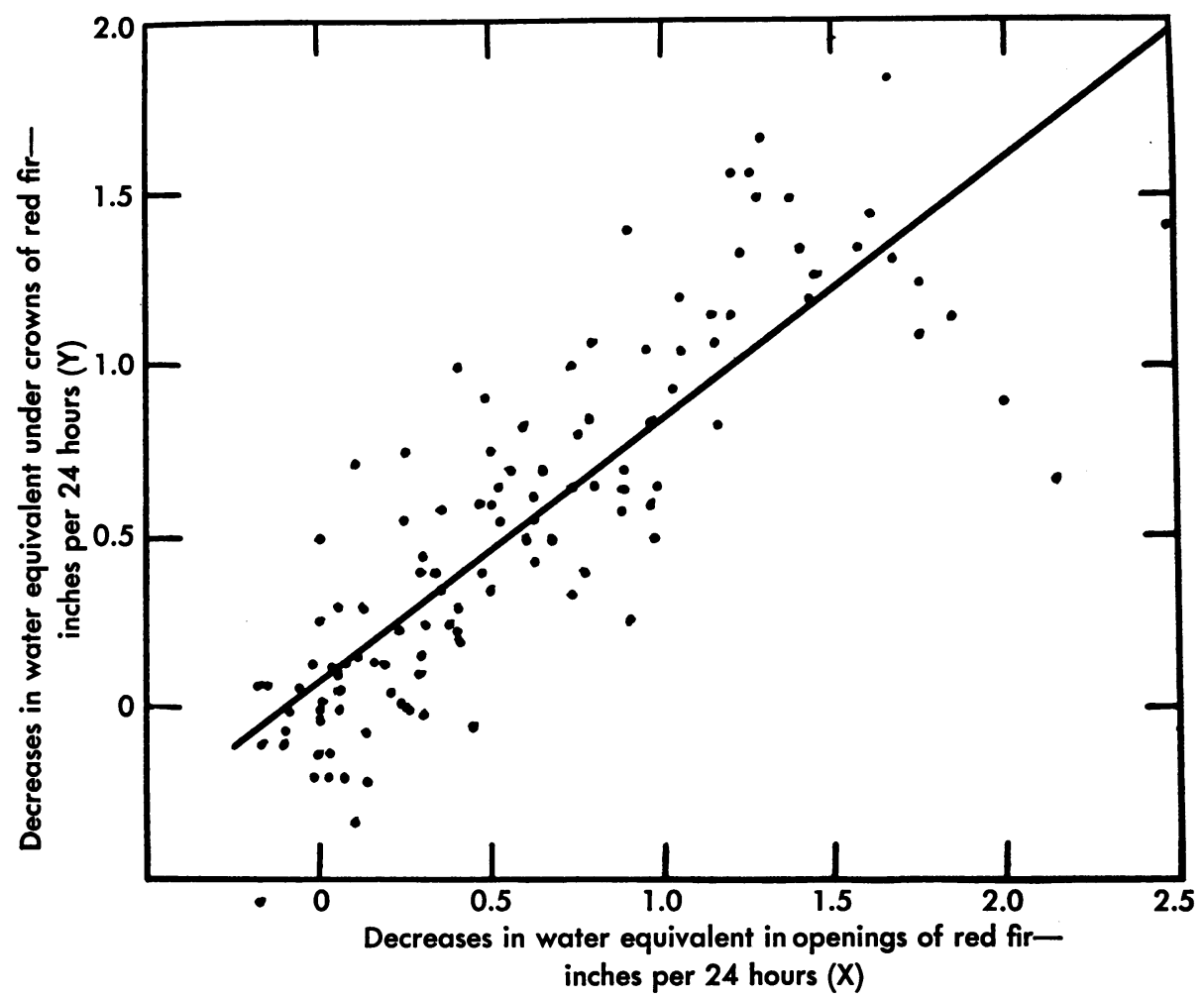

Fig. 90.-Relation of daily decreases in water equivalent of snow under crowns $(Y)$ to those in openings between crowns $(X)$ of red fir, $Y=0.77 X+0.08$.

could be made on one third of the area, the storage of snow would be increased, on the average, by more than 5 inches water equivalent. A heavy cutting in lodgepole pine in Colorado increased snow storage by 3.8 inches water equivalent (38), a figure sufficiently close to those just estimated to provide some confirmation.

In a specific area or drainage basin, the trapping of maximum amounts of snow by creating openings promises to be effective in increasing water yields. Considering larger areas, however, and assuming the snowfall is the same, the excess snow that may be trapped in one area is presumably balanced by a corresponding deficit in another area to leeward in the path of the storms. If this is so, forest management designed to trap maximum amounts of snow involves also the selection, for treatment, of those areas where the water from the snow is most needed.

The losses by interception, which may amount to 25 per cent of the snowfall in dense, uncut forest, could be reduced by at least one half by cuttings to create openings in the stand aggregating more than one half the area. Any system of cutting reduces interception approximately in proportion to the 


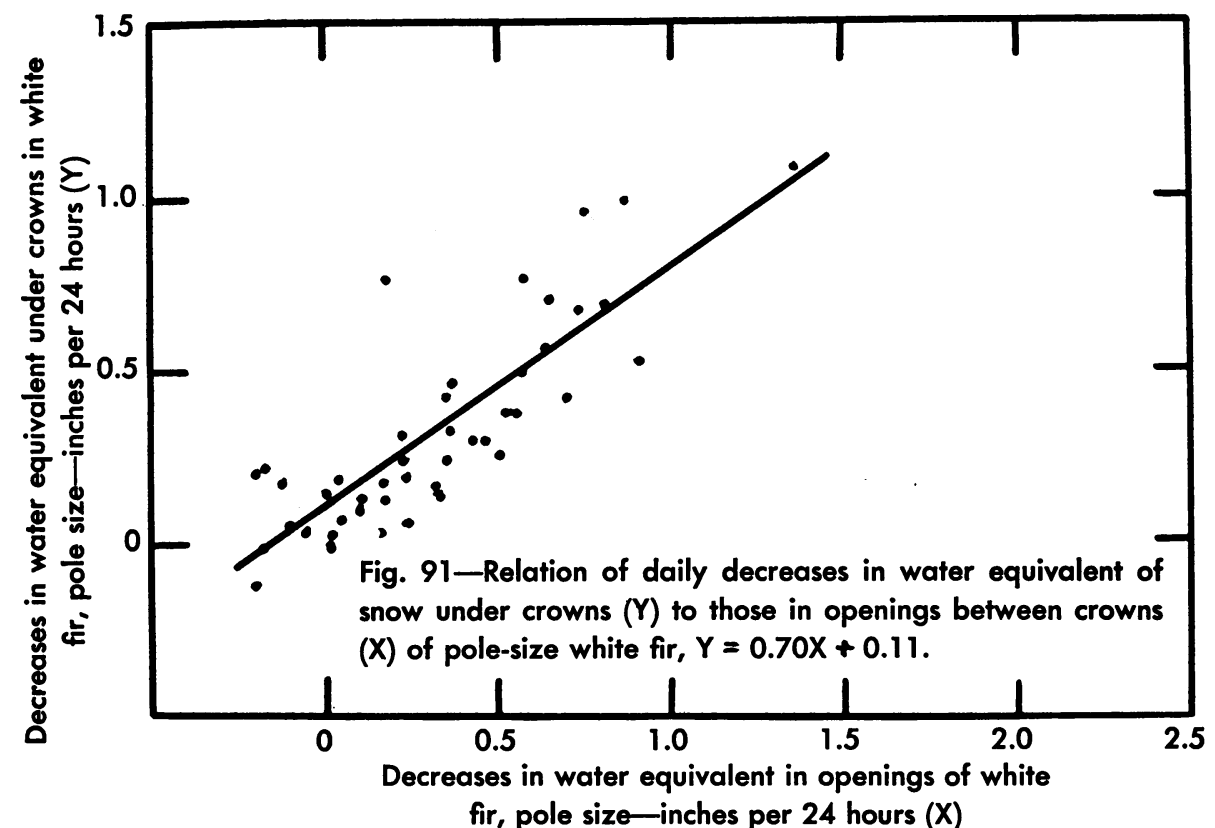

fir, pole size-inches per 24 hours (X)

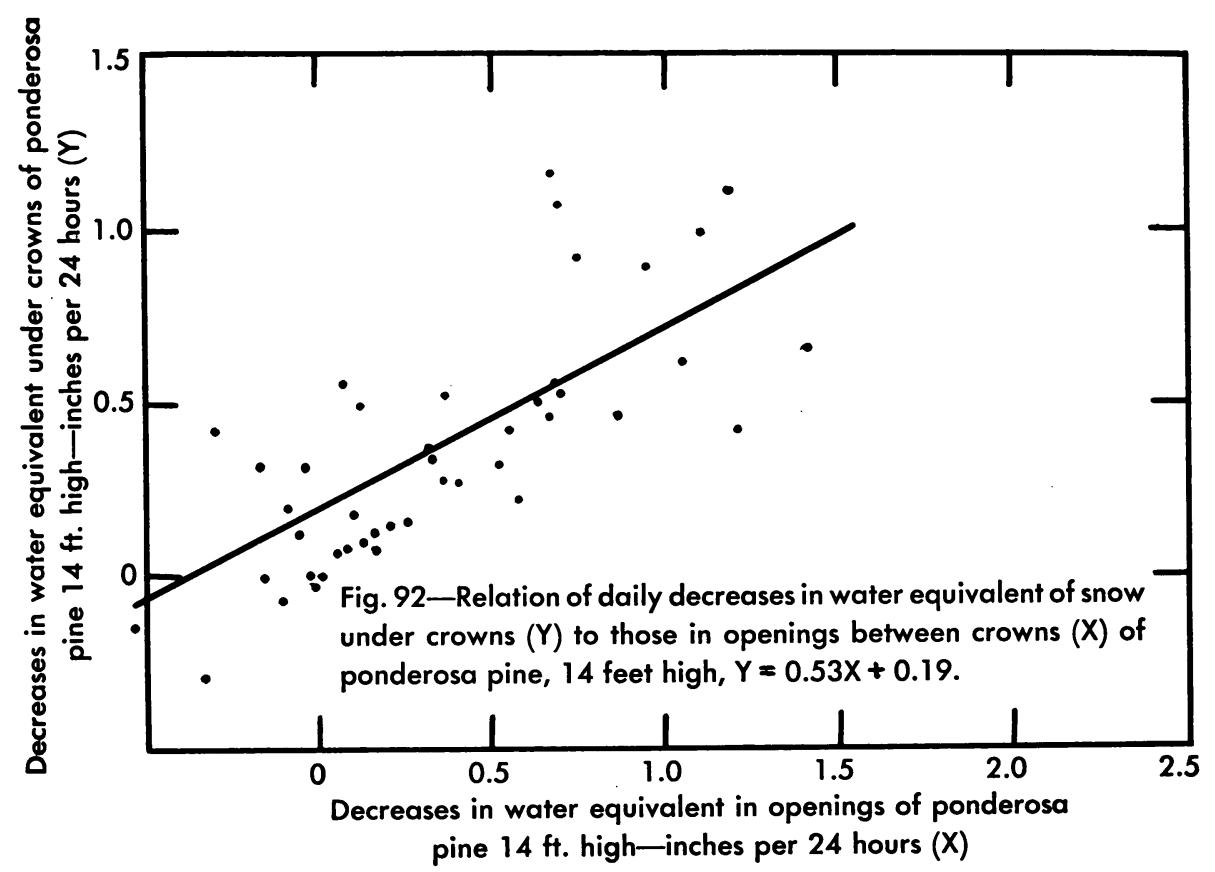


reduction in crown cover. With snowfall of 28 inches water equivalent, the saving of snow would be 3.5 inches of water.

The losses by evaporation in the open are less than 1.5 inches water equivalent for the whole snow season, and half that amount in the forest. Cuttings might increase the evaporation by 0.2 or 0.3 inch for the season-a minor amount which would not be changed appreciably by the kind of silvicultural treatment.

To retard the melting of the snow and to prolong its contribution to streamflow later into the summer involve both the amount of snow in storage and its rate of decrease. It has been shown that maximum amounts of snow will be obtained by creating openings in the forest. If these openings are less than twice the height of the trees in width, the rate of melting will be increased only slightly. In May or June, losses by evaporation are likely to be more than balanced by gains in condensation. Clear cutting in small groups should both yield the most water and prolong the summer flow. Strip cuttings might also give good results if the clear cut strips are narrow, if they follow, as far as possible, the contours, and are oriented east and west rather than north and south. The proportion of the total area that is cut clear in groups or strips, provided they are not much wider than the height of the trees, should be as large as is consistent with the reservation of sufficient areas of uncut timber between to provide screens and be windfirm.

\section{SUMMARY}

The snow in the forested zone of the west slope of the Sierra Nevada is an important source of water. Suggestions for improving the amount and timing of the yields of water from the snow by forest management have been derived from this study of the evolution of the snow cover as it is influenced by different types, ages, and densities of forest. The findings are as follows:

1. New snow in the open had an average density of 10 per cent. Densities under the crowns were from 1 to 5 per cent higher than those in the open.

2. From 13 to 27 per cent of the seasonal snowfall was intercepted by the forest canopies. The larger percentages were in the denser types and under crowns, as compared with openings. In large openings after cutting, there was more snow than in the large clearing. The depth of interception varied with the depth of snowfall per storm.

3 . The maximum depth of total snow on the ground was greater in the open areas or in the stands with large openings where the dates of occurrence of the maximums were also earliest. The dates for maximum depth were earlier than those for maximum water equivalent.

4. The density of the total snow on the ground reached 40 per cent usually in March or April-earlier in the clearings and in the ponderosa pine than in the fir types.

5 . The daily rates of increase in density of the snow average 0.3 to 0.4 per cent. For short periods, they may be 2.0 or 3.0 per cent.

6 . The maximum water equivalents of the total snow on the ground or the amounts of water in storage in the snow are larger in red fir and in the cutover stand with large openings than in the clearings, and smallest in dense 
fir and ponderosa pine stands. The dates of maximums in the forested areas are usually later than in the open areas. Maximum water equivalents in the cutover mixed conifer and in a few other areas, for some years, vary inversely with the crown coverage within a 20 -foot radius.

7. The effect of trees on the south side of the large clearing on the water equivalents of the snow was to maintain greater storage not farther to the north than the height of the trees, as compared with smaller amounts at greater distances where melting was more rapid.

8. Openings between the crowns showed average maximum accumulations of 1 to 5 inches water equivalent larger than did areas under the crowns.

9 . Snow temperatures at 3 inches below the surface were $32^{\circ} \mathrm{F}$ during periods of melting, and below freezing they varied roughly with mean daily air temperatures.

10. I Josses by evaporation from snow decreased as the snow lasted longer, and sometimes became gains by condensation in May or June.

11. The total seasonal evaporation in different forest types varied from 0.01 inch, the lowest, to the highest in any type, which was less than 1.5 inches water equivalent. Mean monthly rates were from -0.01 to 0.3 water equivalent.

12. Evaporation during the night was lower than during the day, and condensation often exceeded evaporation.

13. Evaporation from snow was much lower than that from water.

14. Evaporation tended to be lower in openings than under crowns, probably because condensation was greater.

15. The first exposure of bare ground varied from March 28 to May 5 between extremes in different forest types, and more than 60 days in different years in the same type.

16. The average date of final disappearance of the snow varied from $\Lambda$ pril 17, in the old ponderosa pine, to June 1 in the red fir, and by about 2 months between extreme seasons.

17. The date of disappearance of the snow varied inversely to the crown coverage within a 20 -foot radius in the cutover mixed conifer area, and in some other types in certain years.

18. The average duration of the snow cover varied from 117 days, in the ponderosa pine, to 160 days in the red fir area.

19. The percentage of area covered by snow decreased after the first exposure of bare ground by from 4.4 per cent per day, in the red fir area, to 17.2 per cent in the lower meadow.

20. Cumulated melting varied with cumulated degree-days above freezing although the trends were not always linear and their slopes were not the same in different years.

21. The date of disappearance of the snow was later as the water equivalent of the snow on the ground on March 1 was greater. The same slope of trend was applicable to all types in years of heavy snow.

22 . The average daily rates of decrease in water equivalent from March 1 to disappearance of the snow were lower in the more heavily shaded white fir types, and as the water equivalent on March 1 was lower. For the same water equivalent on March 1, the range between types was only 0.06 inch. 
23. Rates of melting during periods without precipitation averaged less than 0.2 inch per day in all types prior to March 9 . After that date, the rates in the open and cutover areas were above 0.65 inch, and those in the forested areas were below that figure, with a minimum of 0.46 inch in the dense pole white fir area.

24. The daily decreases in water equivalents of the snow in each type could be estimated as a fraction of those in the large clearing.

25. The daily decreases in water equivalents of the snow under the crowns in each type could also be estimated from those in the large clearing.

26 . The daily decreases under the crowns in each type could also be estimated from those in the openings between crowns.

27 . The rates of melting tended to be lower under the crowns than in openings, and lower in openings than in the large clearing, per unit change in the independent variable in each case, but the influence of the trees in retarding melting was quite small.

28. Rates of melting were far below the infiltration capacities of these forested soils, and did not cause surface runoff.

29. Forest cover, by reducing the rate of melting of the snow, may reduce flood crests which result primarily from heavy rains.

30 . Yields of water from snow could be increased by silvicultural management which would create many openings in the forest, of a width between once and twice the height of the trees, in which maximum amounts of snow would be trapped.

31. The same silvicultural treatments, by providing more snow which would last longer, would also prolong the flow of streams later into the summer.

\section{ACKNOWLEDGMENTS}

The author is grateful to those who faithfully made the measurements, often under trying conditions: G. F. Flint, D. T. Gordon, W. B. Scott, F. R. Sodolski, B. S. Sweatt, and K. A. Taber; and also to those who helped with the office work, including R. H. Blanford, H. L. Baker, J. C. Crupper, M. B. Dickerman, C. B. Eaton, E. J. Hodgkins, R. B. Marston, M. F. Smiley, C. C. Wilson, P. J. Zinke, and B. J. Zobel.

\section{LITERATURE CITED}

1. AnONymous

1950. L'étude scientifique de la neige en Suisse. Ann. de l'Ecole Nationale des Eaux et Forêts $12: 247-67$.

2. BURGER, H.

1948. Einfluss des Waldes auf die Höhe der Schneedecke. Jour. Forestier Suisse 99 : $225-31$.

3. California Division of Engineering \& Irrigation 1923. Flow in California streams. Bul. 5:1-557.

4. California Division of Water Resources 1931-1951. California coöperative snow surveys. Snow survey bulletins. (Mimeo.)

5. Church, J. E.

1912. The conservation of snow : its dependence on forests and mountains. Sci. Amer. Sup. 74:145, 152-55. 
6. Church, J. E.

1934. Evaporation at high altitudes and latitudes. Trans. Amer. Geophys. Union II: $326-43$.

7.

1949. Studies on snow melt. Yrbk. Amer. Philosoph. Soc.: 139-40.

8. CLYDE, G. D.

1931. Snow-melting characteristics. Utah Agr. Exp. Sta. Tech. Bul. 231:1-47.

9. Connaughton, C. A.

1935. The accumulation and rate of melting of snow as influenced by vegetation. Jour. Forestry $33: 564-69$.

10. CRoFt, A. R.

1944. Evaporation from snow. Bul. Amer. Met. Soc. $25: 334-37$.

11

1946. Some factors that influence the accuracy of water-supply forecasting in the Intermountain region. Trans. Amer. Geophys. Union 27:375-88.

12. DunFord, E. G., and C. H. NIEDERHOF

1944. Influence of aspen, young lodgepole pine, and open grassland types upon factors affecting water yield. Jour. Forestry 42:673-77.

12a. EHLERS, J. H.

1915. The temperature of leaves of Pinus in winter. Am. Jour. Bot. 2:32-70.

13. Fowells, H. A., and G. H. SCHUBERT

1951. Natural reproduction in certain cutover pine-fir stands of California. Jour. Forestry 49:192-96.

14. GERDEL, R. W.

1948. Penetration of radiation into the snow pack. Trans. Amer. Geophys. Union 29 : $366-74$.

15. Hale, C. E.

1950. Some observations on soil freezing in forest and range lands of the Pacific Northwest. Pac. Northwest For. and Range Exp. Sta., Res. Notes No. 66:1-17.

16. Hallin, W. E.

1951. Unit area control in California forests. Calif. For. and Range Exp. Sta., Res. Notes No. $77: 1-6$.

17. HAYEs, G. L., and J. KITTREDGE

1949. Comparative rain measurements and rain gage performances on a steep slope adjacent to a pine stand. Trans. Amer. Geophys. Union $30: 295-301$.

18. HORTON, R. E.

1934. Water-losses in high latitudes and at high elevations. Trans. Amer. Geophys. Union II: 351-80.

1945. Infiltration and runoff during the snow melting season with forest cover. Trans. Amer. Geophys. Union $26: 59-68$.

20. Horton, R. E., and H. R. LeACH

1934. Snow surface temperature. Mo. Wea. Rev. 62:128-30.

21. KITTREDGE, J.

1948. Forest influences. 394 pp. MeGraw-Hill Book Co., N. Y.

22. KitTredge, J., H. J. Loughead, and A. MAzuraK

1941. Interception and stemflow in a pine plantation. Jour. Forestry $39: 505-22$.

23. LAMB, J., JR., J. S. ANDREWS, and A. F. Gustafson

1944. Experiments in the control of soil erosion in southern New York. Cornell Agr. Exp. Sta. Bul. 811:1-32.

24. Miles, S. R.

1935. Rapid and easy method of testing reliability of an average. Jour. Amer. Soc. Agron. 27:21-31.

25. NiederhoF, C. H., and E. G. DUNFoRd

1942. The effects of openings in a young lodgepole pine forest on the storage and melting of snow. Jour. Forestry $40: 802-5$.

26. Peasley, P., W. U. Garstka, and B. C. Goodell

1949. Progress in snow-melt investigations at Fraser Experimental Forest. Rept. No. 1, The 1948 season: $1-65$. (Mimeo.) 
27. Rowe, P. B.

1948. Influence of woodland chaparral on water and soil in central California. Calif. For. and Range Exp. Sta. June, 1948:70 pp.

28. Rowe, P. B., and T. M. Hendrix

1951. Interception of rain and snow by second-growth ponderosa pine. Trans. Amer. Geophys. Union $32: 903-8$.

29. U. S. Forest SERvice

1948. Watershed management. Ann. Rpt. Rocky Mountain Forest and Range Exp. Sta.: 22-29. (Mimeo.)

1950. Stream flow and water yield. Ann. Rpt. Rocky Mountain Forest and Range Exp. Sta. : 8-16. (Mimeo.)

31. U. S. Geological Survey

$1935,1936,1937,1938,1939,1941,1942$. Surface water supply of the United States. Pacific slope basins in California. Water-supply Papers 766, 791, 811, 831, 861, 901, 931.

32. U. S. WEATHER BUREAU

1947. Hydrometeorological $\log$ of the Central Sierra Snow Laboratory, 1945-1946. Coöperative Snow Investigations, Tech. Rpt. No. 5:1-62.

33.

1948. Hydrometeorological log of the Upper Columbia Snow Laboratory, 1945-1946. Coöperative Snow Investigations, Tech. Rpt. No. 7:1-53.

34. 1949. Hydrometeorological log of the Upper Columbia Snow Laboratory, 1947-1948. Coöperative Snow Investigations, Tech. Rpt. No. 20-1:1-200.

35. - 1950. Progress report, 1945-1950. Coöperative Snow Investigations, Tech. Rpt. No. 6-4:1-20.

36. WILM, H. G.

1948. The influence of forest cover on snow melt. Trans. Amer. Geophys. Union 29 : 547-56.

37. Wilm, H. G., and M. H. Collet

1940. The influence of a lodgepole pine forest on storage and melting of snow. Trans. Amer. Geophys. Union II:505-8.

38. WILM, H. G., and E. G. DUNFORD

1948. Effect of timber cutting on water available for stream flow from a lodgepole pine forest. U. S. Dept. Agr. Tech. Bul. $968: 1-43$.

39. Wilm, H. G., and C. H. NiederhoF

1941. Interception of rainfall by mature lodgepole pine. Trans. Amer. Geophys. Union III: $660-66$.

40. Wilson, W. T.

1941. An outline of the thermodynamies of snow-melt. Trans. Amer. Geophys. Union I : 182-95.

41. Wisler, C. O., and E. F. Brater

1949. Hydrology. 419 pp. John Wiley \& Sons, N. Y.

42. Work, R. A.

1948. Snow layer density changes. Trans. Amer. Geophys. Union 29, Part I:525-45.

43. Young, A. A.

1948. Evaporation from water surfaces in California. Basic data. Calif. Div. Water Resources, Bul. 54-A : 1-205. 
The journal Hilgardia is published at irregular intervals, in volumes of about 600 pages. The number of issues per volume varies.

Subscriptions are not sold. The periodical is sent as published only to libraries, or to institutions in foreign countries having publications to offer in exchange.

You may obtain a single copy of any issue free, as long as the supply lasts; please request by volume and issue number from:

\section{Publications Office \\ College of Agriculture \\ Berkeley 4, California}

The limit to nonresidents of California is 10 separate issues on a single order. A list of the issues still available will be sent on request. 